\title{
Hanford Cultural Resources Laboratory Annual Report for Fiscal Year 1993
}
G. V. Last
M. K. Wright
M. V. Dawson
M. E. Crist
K. A. Simmons
N. A. Cadoret
D. W. Harvey
J. G. Longenecker

September 1994

Prepared for

the U.S. Department of Energy

under Contract DE-AC06-76RLO 1830

Pacific Northwest Laboratory

Richland, Washington 99352 



\section{DISCLAIMER}

This report was prepared as an account of work sponsored by an agency of the United States Government. Neither the United States Government nor any agency thereof, nor any of their employees, make any warranty, express or implied, or assumes any legal liability or responsibility for the accuracy, completeness, or usefulness of any information, apparatus, product, or process disclosed, or represents that its use would not infringe privately owned rights. Reference herein to any specific commercial product, process, or service by trade name, trademark, manufacturer, or otherwise does not necessarily constitute or imply its endorsement, recommendation, or favoring by the United States Government or any agency thereof. The views and opinions of authors expressed herein do not necessarily state or reflect those of the United States Government or any agency thereof. 


\section{DISCLAIMER}

Portions of this document may be illegible in electronic image products. Images are produced from the best available original document. 


\section{Executive Summary}

The Hanford Cultural Resources Laboratory (HCRL) was established by the U.S. Department of Energy, Richland Operations Office (DOE-RL) in 1987 as part of Pacific Northwest Laboratory (PNL). The HCRL provides support for managing the archaeological, historical, and cultural resources of the Hanford Site, Washington, consistent with the National Historic Preservation Act of 1966 (NHPA), the Archaeological Resources Protection Act of 1979, the Native American Grave Protection and Repatriation Act of 1990, and the American Indian Religious Freedom Act of 1978. The HCRL responsibilities have been set forth in the Hanford Cultural Resources Management Plan as a prioritized list of tasks to be undertaken to keep the DOE-RL in compliance with federal statutes, regulations, and guidelines.

For FY 1993, these tasks were to:

- conduct cultural resource reviews pursuant to Section 106 of the NHPA

- monitor the condition of known historic properties

- identify, recover, and inventory artifacts collected from the Hanford Site

- educate the public about cultural resources values and the laws written to protect them

- conduct surveys of the Hanford Site in accordance with Section 110 of the NHPA.

Research also was conducted as a spin-off of these tasks and is reported here.

National Historic Preservation Act Section 106 compliance reviews are conducted prior to each proposed ground disturbing and building alteration/demolition project on the Hanford Site. During FY 1993, Hanford contractors requested 437 Section 106 reviews, 24 of which required archaeological surveys and 27 of which required building documentation. The surveys conducted in FY 1993 also included five projects initiated in previous years; these surveys covered a total of approximately $15.31 \mathrm{~km}^{2}$, and resulted in the discovery of three prehistoric archaeological sites, 79 historic archaeological sites, and four archaeological sites with both historic and prehistoric components. Proper mitigative actions were taken to avoid any potential impact to sites considered eligible for listing on the National Register of Historic Places.

The archaeological site monitoring program is designed to determine whether DOE-RL's cultural resource management and protection policies are effective. Results of monitoring are used in planning for cultural resource site management and protection. Forty sites, including 16 cemetery sites, were monitored during this fiscal year. 



\section{Acknowledgments}

The Hanford Cultural Resources Laboratory (HCRL) is indebted to several people for their contributions of time and effort in creating this document. Thanks go to Peggy Riechers, who artfully created many of the maps and several tables; Janet O'Mara, our skillful editor; Ernest Antonio, who peer reviewed the report; and all of the people in Text Processing who worked on the document. Many thanks also go to George Last, our dedicated Project Manager, for helping with the administrative aspects of creating the report. 
. 


\section{Abbreviations}

$\begin{array}{ll}\text { AIRFA } & \text { American Indian Religious Freedom Act } \\ \text { ALE } & \text { Arid Lands Ecology Reserve } \\ \text { ARPA } & \text { Archaeological Resources Protection Act } \\ \text { BN } & \text { Benton County } \\ \text { CERCLA } & \text { Comprehensive Environmental Response, Compensation, and Liability Act } \\ \text { CFR } & \text { Code of Federal Regulations } \\ \text { DOE-RL } & \text { U.S. Department of Energy, Richland Operations Office } \\ \text { ERDA } & \text { U.S. Energy Research and Development Administration } \\ \text { ERDF } & \text { Environmental Restoration Disposal Facility } \\ \text { FR } & \text { Franklin County } \\ \text { GIS } & \text { Geographic Information System } \\ \text { GR } & \text { Grant County } \\ \text { HCRC\# } & \text { Hanford Cultural Resources Case Number } \\ \text { HCRL } & \text { Hanford Cultural Resources Laboratory } \\ \text { HCRMP } & \text { Hanford Cultural Resources Management Plan } \\ \text { HEIS } & \text { Hanford Environmental Information System } \\ \text { IVDTS } & \text { Integrated Voice/Data Telecommunications } \\ \text { KEH } & \text { Kaiser Engineers Hanford Company } \\ \text { MCAS } & \text { Mid-Columbia Archaeological Society } \\ \text { MPD } & \text { Multiple Property Documentation } \\ \text { NAGPRA } & \text { Native American Grave Protection and Repatriation Act } \\ \text { NHPA } & \text { National Historic Preservation Act } \\ \text { NORCUS } & \text { Northwest Organization of Colleges and Universities for Science } \\ \text { NRHP } & \text { National Register of Historic Places } \\ \text { PA } & \text { Programmatic Agreement } \\ \text { PNL } & \text { Pacific Northwest Laboratory } \\ \text { RCRA } & \text { Resource Conservation and Recovery Act } \\ \text { TEDF } & \text { Treated Effluent Disposal Facility } \\ \text { TRAC } & \text { Teacher Research Associate Program } \\ \text { USACE } & \text { United States Army Corps of Engineers } \\ \text { WHC } & \text { Westinghouse Hanford Company } \\ \text { WPPSS } & \text { Washington Public Power Supply System } \\ & \end{array}$


. 


\section{Glossary}

Aeolian deposits - Sediments deposited as the result of wind.

Anthropogenic disturbance - Disturbance as a result of human action.

Archaeological site - The locus of concentrated human activity, indicated by the presence of artifacts in specified densities. The HCRL defines a site as artifacts found in groups of three or more with less than $10 \mathrm{~m}$ between objects, or groups of more than one feature.

Artifact - Anything with form or position that cannot be attributed to natural processes.

Bifacial/Biface - A stone tool bearing flake scars on both faces.

Bioturbation - Disturbance caused by animal activity.

Cairn - A feature defined by a concentration of rocks.

Cistern -- An artificial reservoir or tank for holding water.

Core - A mass of material often performed by the worker to the desired shape to allow the removal of a definite type of flake or blade.

Diagnostic artifact - An artifact which has characteristics unique to a single period of prehistory or history.

Feature - A non-portable artifact or close association of artifacts.

Fire-cracked rock - Rock which has been modified by fire.

Flake - Any piece of stone removed from a larger mass by the application of force, either intentional, accidentally, or by nature. In this report, we consider flakes to be only the result of intentional human activities.

Hammer stone -- A tool that is usually a round or rounded nodule of stone that shows evidence of battering on one or more ends.

Housepit - A semi-subterranean dwelling.

Isolate -- The HCRL defines an isolate as a group of one to two artifacts found within less than $10 \mathrm{~m}$ of each other, and/or farther than $20 \mathrm{~m}$ from a site. 
Lithic debitage - Residual stone material resulting from tool manufacture. Useful to determine tool making techniques.

Net weight - A notched cobble used with fishing nets.

Paleontological site -- A site containing animal remains which may be fossilized.

Projectile point - A spear point, dart point, or arrow point.

Scraper - An implement with beveling on one or more margins of a flake or blade to obtain a strong cutting edge. 


\section{Contents}

Executive Summary $\ldots \ldots \ldots \ldots \ldots \ldots \ldots \ldots \ldots \ldots \ldots \ldots \ldots \ldots$ iii

Acknowledgements $\ldots \ldots \ldots \ldots \ldots \ldots \ldots \ldots \ldots \ldots \ldots \ldots \ldots \ldots \ldots$

Abbreviations $\ldots \ldots \ldots \ldots \ldots \ldots \ldots \ldots \ldots \ldots \ldots \ldots \ldots \ldots \ldots \ldots \ldots \ldots \ldots \ldots \ldots$

Glossary $\ldots \ldots \ldots \ldots \ldots \ldots \ldots \ldots \ldots \ldots \ldots \ldots \ldots \ldots \ldots \ldots \ldots \ldots$

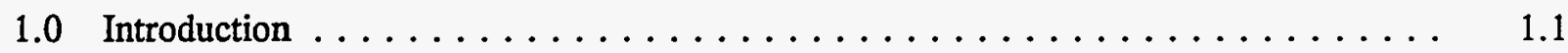

2.0 Section 106 Compliance Reviews $\ldots \ldots \ldots \ldots \ldots \ldots \ldots \ldots \ldots \ldots \ldots \ldots$

2.1 Reviews Conducted $\ldots \ldots \ldots \ldots \ldots \ldots \ldots \ldots \ldots \ldots \ldots \ldots \ldots$

2.2 Cultural Resources Identified $\ldots \ldots \ldots \ldots \ldots \ldots \ldots \ldots \ldots \ldots$

2.3 ERDF Survey, North Slope Site Recordation, and 100 Area Operable

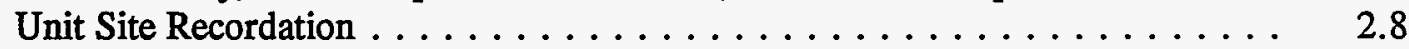

2.3.1 Environmental Restoration Disposal Facility . . . . . . . . . . . 2.8

2.3.2 The North Slope Waste Sites . . . . . . . . . . . . . . . 2.9

2.3.3 The 100 Area Operable Unit . . . . . . . . . . . . . . 2.9

3.0 The Monitoring Program $\ldots \ldots \ldots \ldots \ldots \ldots \ldots \ldots \ldots \ldots \ldots \ldots \ldots \ldots$

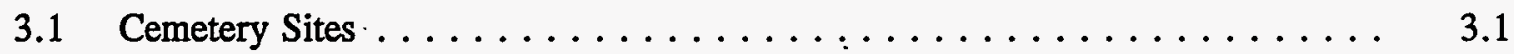

3.2 Sites Listed on the National or State Register of Historic Places . . . . . . . 3.4

3.3 Sites Not Listed on the National Register of Historic Places . . . . . . . 3.5

3.4 Conclusions and Recommendations $\ldots \ldots \ldots \ldots \ldots \ldots \ldots \ldots \ldots \ldots \ldots \ldots \ldots$

4.0 The Inventory $\operatorname{Program} \ldots \ldots \ldots \ldots \ldots \ldots \ldots \ldots \ldots \ldots \ldots$

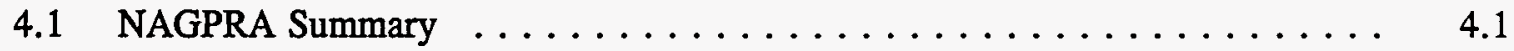

5.0 The Public Education Program $\ldots \ldots \ldots \ldots \ldots \ldots \ldots \ldots \ldots \ldots$

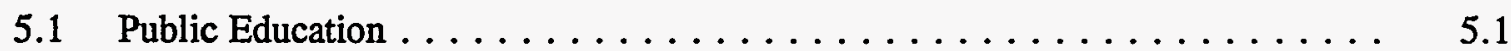

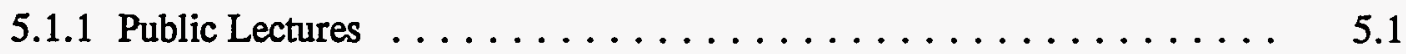

5.1 .2 Media Exposure $\ldots \ldots \ldots \ldots \ldots \ldots \ldots \ldots \ldots \ldots \ldots \ldots$ 


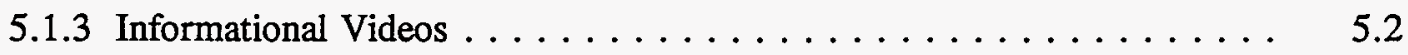

5.1 .4 Displays . . . . . . . . . . . 5.2

5.2 Interns and Researchers $\ldots \ldots \ldots \ldots \ldots \ldots \ldots \ldots \ldots \ldots \ldots \ldots \ldots \ldots \ldots .2$

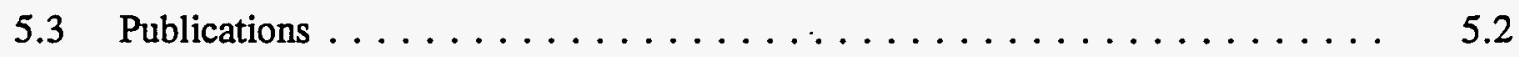

6.0 NHPA Section 110 Survey $\ldots \ldots \ldots \ldots \ldots \ldots \ldots \ldots \ldots \ldots \ldots \ldots \ldots \ldots \ldots \ldots$

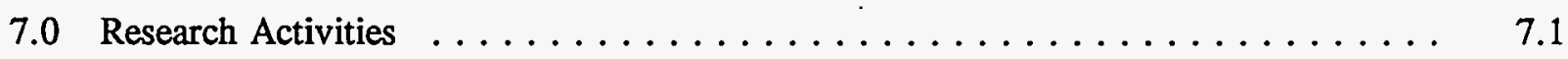

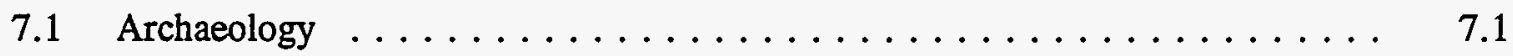

$7.1 .1 \mathrm{Human} /$ Resource Interaction $\ldots \ldots \ldots \ldots \ldots \ldots \ldots \ldots \ldots . \ldots \ldots . \ldots \ldots$

7.1.2 Early Euro-American Settlement Patterns . . . . . . . . . 7.1

7.1.3 Impacts of the Manhattan Project $\ldots \ldots \ldots \ldots \ldots \ldots \ldots \ldots .7 .2$

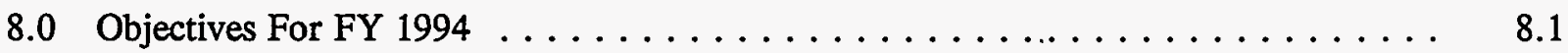

8.1 NHPA Section 106 Compliance $\ldots \ldots \ldots \ldots \ldots \ldots \ldots \ldots \ldots .1$

8.2 NHPA Section 110 Compliance $\ldots \ldots \ldots \ldots \ldots \ldots \ldots \ldots \ldots .2$

8.2 .1 Multiple Property Documentation Form . . . . . . . . . 8.2

$8.3 \quad$ Data Management . . . . . . . . . . . . .

8.3.1 Development in Phases . . . . . . . 8.3

8.3.2 Options for Design and Implementation $\ldots \ldots \ldots \ldots \ldots \ldots \ldots .8 .4$

8.3 .3 Summary $\ldots \ldots \ldots \ldots \ldots \ldots \ldots \ldots \ldots \ldots \ldots \ldots \ldots .4$

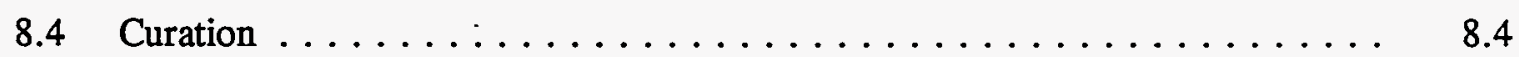

8.5 Archaeological Protection $\ldots \ldots \ldots \ldots \ldots \ldots \ldots \ldots \ldots \ldots \ldots \ldots \ldots \ldots$

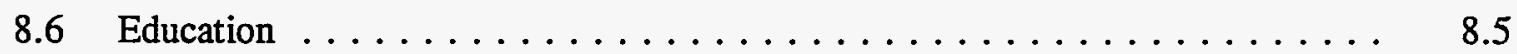

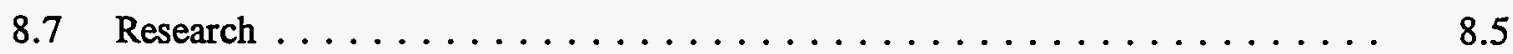

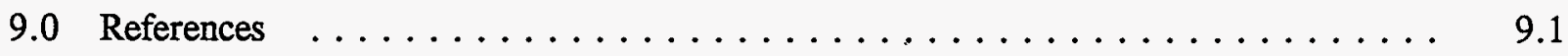

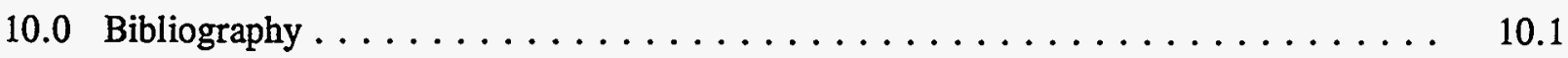

Appendix A - Section 106 Reviews Conducted in FY $1993 \ldots \ldots \ldots \ldots \ldots$ A.1

Appendix B - Surveys and Site Recordations Performed in FY $1993 \ldots \ldots \ldots \ldots$ B.1

Appendix C - Sites Monitored During the FY 1993 Monitoring Cycle $\ldots \ldots \ldots \ldots$ C.1

Appendix D - Presentations and Publications by the HCRL Staff in FY $1993 \ldots \ldots \ldots$ D.1 


\section{Figure}

2.1 Survey/Site Recordation Areas for the ERDF, $100 \mathrm{HR}-3$ Operable Unit, and

North Slope Waste Sites

2.10

xiii 


\section{Tables}

2.1 Surveys Completed in FY 1993 for 106 Reviews $\ldots \ldots \ldots \ldots \ldots$

2.2 Construction Monitoring Completed in FY 1993 for Section 106 Reviews . . . . . . . 2.4

2.3 Archaeological Sites Identified in FY $1993 \ldots \ldots \ldots \ldots \ldots \ldots \ldots \ldots \ldots \ldots$

3.1 Summary of Sites Monitored During $1993 \ldots \ldots \ldots \ldots \ldots . \ldots \ldots$ 


\subsection{Introduction}

The Hanford Cultural Resources Laboratory (HCRL) was established by the U.S. Department of Energy, Richland Operations Office (DOE-RL) in 1987 as part of Pacific Northwest Laboratory (PNL) $^{(a)}$. The HCRL provides support for managing the archaeological, historical, and cultural resources of the Hanford Site, Washington, consistent with the National Historic Preservation Act, amended 1992 (NHPA), the Archaeological Resources Protection Act of 1979 (ARPA), the American Indian Religious Freedom Act of 1978 (AIRFA), and the Native American Grave Protection and Repatriation Act of 1990 (NAGPRA). In addition, the HCRL conducts research into the human past and climate change using archaeological data from the Hanford Site and elsewhere.

The HCRL's activities are governed by the Hanford Cultural Resources Management Plan (HCRMP) (Chatters 1989), which established policies and procedures for compliance with federal statutes and regulations. The HCRMP includes a prioritized list of tasks that guides cultural resource management activities each year. Tasks performed during FY 1993 were, in order of priority, to conduct NHPA Section 106 Reviews; monitor the condition of known historic properties; identify, recover, and inventory artifacts collected from the Hanford Site; educate the public about cultural resource values and the laws written to protect them; and conduct surveys of the Hanford Site in accordance with Section 110 of the NHPA.

This report includes a chapter for each task, in order of priority. Each chapter includes an explanation of the task, the tactics used to perform it, and summaries of the results. Supporting detail is provided in Appendixes A through D.

(a) PNL is operated for the U.S. Department of Energy by Battelle Memorial Institute. 


\subsection{Section 106 Compliance Reviews}

As required by Section 106 of the NHPA, the HCRL reviews each proposed ground disturbing or building alteration/demolition project to determine if it may impact any cultural property that is listed on or eligible for the National Register of Historic Places (NRHP). This is accomplished through HCRL's cultural resources review process (Chatters 1989: Section 3.1.1). For efficiency, cultural resource reviews are classified according to four criteria: whether the project entails maintenance or new construction; the existence of previous disturbance in the area to be reviewed; the cultural resource sensitivity of the area in which the activity is planned; and whether the project involves any existing structure or building. Using these criteria, projects may fall into any one or a combination of two or more of six project classes:

- Class I, maintenance in a disturbed, low sensitivity area

- Class II, maintenance in a disturbed, high sensitivity area

- Class III, new construction in a disturbed low sensitivity area

- Class IV, new construction in a disturbed, high sensitivity area

- Class V, all projects involving undisturbed ground

- Class VI, projects involving demolition or remodeling of existing structures.

Each class requires a different response, as specified in Section 3 of the HCRMP (Chatters 1989).

\subsection{Reviews Conducted}

In the spring of 1993, the HCRL adopted new methods of processing Section 106 reviews. The "verbal clearance" process was eliminated in March 1993, except in instances where employee safety was at risk. The number of reviews that needed to be fully processed thus increased dramatically from 247 in FY 1992 to 437 in FY 1993.

During FY 1993, Hanford contractors requested 437 cultural resources reviews. Most cases initiated this year were Class III reviews (176) and Class I (111), followed by Class VI (85), Class V (22), mixed Class III/V (9), Class II (7), mixed Class III/VI (7), mixed Class I/III (6), Class IV (4), mixed Class III/IV (4), and one each of the mixed Classes I/II, I/VI, I/III/V, I/III/VI, $\mathrm{III} / \mathrm{IV} / \mathrm{V}$, and IV/V. Twenty-six of the Class I reviews and 4 of the Class III reviews were given verbal clearances. The majority of the reviews were requested for the 200 Areas (185), followed by the 100 and 300 Areas (91 and 89 respectively), and the 600 Area (49). The remainder are fairly equally divided between the 400,1100 , and 3000 Areas, and DOE-administered lands outside of the Hanford Site boundaries. See Appendix A for a list of all projects reviewed in FY 1993.

Class I cases, formerly requested verbally, are now required to be formally requested by Hanford contractors and reviewed by the HCRL as any other project. Since these projects require maintenance 
work on existing facilities only, the project area has been previously disturbed. The focus of the review for these projects, therefore, is not to determine the disturbance level but instead to determine if the project will occur in a culturally sensitive location. The review includes an examination of site and sensitive area location maps.

The treatment of Class II and Class IV projects did not change throughout FY 1993. These projects were monitored except in some instances where the disturbance in the project area was so great and deep that any archaeological deposits that may once have existed would most certainly have been destroyed by previous construction.

Like the Class I cases, all Class III projects now must be formally requested and reviewed. The focus of the reviews for these projects is both to determine the level of previous disturbance and sensitivity of the project area. The review includes an examination of recent aerial photographs, site and sensitive area location maps, and, if necessary, records associated with any nearby surveys and/or sites.

Class V projects nearly always require a survey, if one has not been conducted of the area previously. Reviews of these areas include an examination of aerial photographs to determine if the entire project area is undisturbed, an examination of site and survey maps to determine if any sites exist or surveys have been done on or near the project area, and, if necessary, a records review of information associated with these sites and surveys. Of the Class V projects initiated in FY 1993, several did not require surveys, one project was delayed and eventually replaced by a different project, six were in areas that had been previously surveyed, two were postponed and one canceled, one did not require a survey due to the scope of the work, and three remain to be completed and will be included in the FY 1994 Annual Report.

Class VI projects increased almost tenfold from nine in FY 1992 to 85 in FY 1993. Twenty-seven of these projects involved building demolitions. Documentation of these facilities was started in the summer of FY 1993, and will be completed in FY 1994. Fifty-five other projects involved building modifications, which required research into the date of construction of the facility and how it has been used since construction. From that information, a decision about the building's eligibility for inclusion on the NRHP is made. If the facility is potentially eligible for the NRHP, the HCRL staff determines if the project will have an effect on any characteristics of the facility that would make it eligible. If the project will have an effect on the facility, further measures to mitigate the impacts are taken. If there will be no effect, or if the facility is not potentially eligible for the NRHP, a letter is written which states that either the facility is not eligible or that it is eligible but the project will have no effect on any characteristics of the facility that would make it eligible.

Twenty-four Class V cases received in FY 1993 required surveys (Table 2.1) and four required monitoring (Table 2.2). Five projects which required surveys that were initiated in previous years also were surveyed in FY 1993. Three Section 106 reviews required extensive fieldwork, two of which were initiated in previous years: the North Slope Waste Sites Project (92-600-028) and the 
Table 2.1. Surveys Completed in FY 1993 for 106 Reviews

\begin{tabular}{|c|c|c|c|}
\hline Case Number & Project Name & Area $\left(\mathrm{km}^{2}\right)$ & $\begin{array}{c}\text { Cultural } \\
\text { Resources }\end{array}$ \\
\hline 91-100-CERCLA & 100 Operable Unit & Site recordation & 27 sites \\
\hline $91-300-024$ & $\begin{array}{l}\text { Environmental Molecular Science } \\
\text { Laboratory (EMSL) }\end{array}$ & 0.1 & 1 site \\
\hline $92-600-028$ & North Slope Waste Sites & Site recordation & 21 sites \\
\hline $\begin{array}{l}92-600-29 / \\
92-600-030\end{array}$ & $\begin{array}{l}\text { Integrated Voice/Data Telecommunications } \\
\text { System (IVDTS) }\end{array}$ & 1.29 & 1 site \\
\hline $92-600-041$ & Fire Pump Mods at Building 6652-PH & 0.000001 & none \\
\hline $93-100-005$ & Monitoring Well \#199-N-N81 & 0.0009 & none \\
\hline $93-100-017$ & 3 Wells at Grout Treatment Facility & 0.0018 & none \\
\hline $93-100-029$ & Columbia River Siren System & 0.00001 & none \\
\hline $93-200-001$ & $\begin{array}{l}\text { Environmental Restoration Disposal Facility } \\
\text { (ERDF) }\end{array}$ & 11.0 & $\begin{array}{l}5 \text { sites, } \\
9 \text { isolates }\end{array}$ \\
\hline $93-200-004$ & 200-BP-1 Hanford Prototype & 0.02 & none \\
\hline $93-200-005$ & Water Line Repair at 2704-S & 0.000002 & none \\
\hline $93-200-027$ & Waste Sampling \& Char. Facility & 0.06 & none \\
\hline $93-300-028$ & City of Richland Option & 0.00008 & none \\
\hline $93-600-001$ & W-058 Cross Site Transfer System & 0.14 & none \\
\hline $93-600-002$ & Expansion of Gravel Pits 23 \& 30 & 0.15 & none \\
\hline $93-600-004$ & Multi Function Waste Tank Facility & 0.11 & none \\
\hline $93-600-005$ & L-102 Primary Highway & 1.80 & 2 sites \\
\hline $93-600-011$ & Microbial Origins Project & 0.02 & none \\
\hline $93-600-012$ & Sagebrush Restoration Research & 0.20 & none \\
\hline $93-600-013$ & IVDTS Job \#ISV and 300N Area & 0.02 & none \\
\hline $93-600-014$ & SR 240 Access Road & 0.27 & 2 sites \\
\hline $93-600-016$ & Hanford Well/Borehole Survey & 0.00009 & none \\
\hline $93-600-017$ & WPPSS Emergency Sirens & 0.00093 & none \\
\hline $93-600-019$ & Hanford Patrol Power Line Extension & 0.01 & none \\
\hline $93-600-021$ & IVDTS under SR 240 & 0.002 & none \\
\hline $93-600-028$ & W-152 (ERDF area wells) & with ERDF & none \\
\hline $93-600-042$ & Selected ALE Cleanup Sites (USCOE) & 0.13 & $\begin{array}{l}27 \text { sites, } \\
1 \text { isolate }\end{array}$ \\
\hline $93-0000-002$ & DH-5 Abandonment (Mattawa) & 0.0005 & none \\
\hline
\end{tabular}


Table 2.2. Construction Monitoring Completed in FY 1993 for Section 106 Reviews

\begin{tabular}{||l|l|l||}
\hline Case Number & \multicolumn{1}{|c|}{ Project Name } & Cultural Resources \\
\hline $\begin{array}{l}88-300-037 / \\
89-300-032\end{array}$ & $\begin{array}{l}\text { 300 Area Electrical Distribution } \\
\text { Conversion, Phases 1 and II }\end{array}$ & none \\
\hline $93-300-029$ & 300-FF-5 Groundwater Well & none \\
\hline $93-600-017$ & WPPSS Emergency Sirens & none \\
\hline $93-600-019$ & Hanford Patrol Power Line Extension & none \\
\hline
\end{tabular}

100 HR-3 Operable Unit (91-100-CERCLA). The Environmental Restoration Disposal Facility (ERDF) (93-200-001) was begun in 1993. The North Slope project required documenting 21 military sites, in addition to the eight cistern sites that were recorded in FY 1992. The ERDF Project involved the survey of $11.0 \mathrm{~km}^{2}$; five sites and nine isolates were recorded. The 100 Area Project involved recording 27 sites at selected locations in the 100-HR-3 Operable Unit, where historic sites were known to be located based on historic records. Highlights of the three projects are outlined in Section 2.3 and Appendix B.

Twenty-eight surveys were completed totaling approximately $15.31 \mathrm{~km}^{2}$. The largest project, ERDF, covered $11.0 \mathrm{~km}^{2}$ and two other surveys had areas greater than $1 \mathrm{~km}^{2}$. The majority of surveys occurred in the 600 Area (17), followed by the 100 Area and 200 Area (4 each), 300 Area (1), and one outside of the Hanford Site (see Table 2.1 and Appendix B).

Four construction projects were monitored during FY 1993, one of which was initiated earlier (see Table 2.2). Four additional projects initiated in FY 1993 require monitoring which will be completed when construction begins.

The ongoing 300 Area Treated Effluent Disposal Facility (TEDF) project was redesigned in FY 1993 to avoid a known archaeological site. This redesign was a very successful preservation effort coordinated with the State Historic Preservation Office and included the placement of a pipeline across the ground surface of the site instead of underground, as originally designed. The redesign eliminated the need to mitigate the impacts of trenching through the archaeological site.

\subsection{Cultural Resources Identified}

Eighty-six new archaeological sites were recorded in FY 1993 (see Table 2.3). Most of the sites were recorded during three projects: 27 sites were recorded during the 100-HR-3 Operable Unit (91-100-CERCLA), 21 military sites were recorded for the North Slope Waste Sites project, and 
Table 2.3. Archaeological Sites Identified in FY 1993

\begin{tabular}{|c|c|c|c|c|}
\hline $\begin{array}{l}\text { HCRL Temp. } \\
\text { Number }\end{array}$ & $\begin{array}{l}\text { Washington } \\
\text { Number }\end{array}$ & Site Type & Category & Project Number \\
\hline HT-93-001 & & Can scatter & Historic & $93-600-014$ \\
\hline HT-93-002 & & Can scatter/dump & Historic & $93-600-014$ \\
\hline HT-93-003 & $3-119$ & Can scatter & Historic & $93-600-005$ \\
\hline HT-93-004 & $3-120$ & $\begin{array}{l}\text { Concrete block } \\
\text { foundation }\end{array}$ & Historic & $93-600-005$ \\
\hline HT-93-005 & $3-121$ & Irrigation valve system & Historic & $\begin{array}{l}92-600-029 / \\
92-600-030\end{array}$ \\
\hline HT-93-006 & & Anti-aircraft site & Late Historic & $92-600-028$ \\
\hline HT-93-007 & & Anti-aircraft site & Late Historic & $92-600-028$ \\
\hline HT-93-008 & & Anti-aircraft site & Late Historic & $92-600-028$ \\
\hline HT-93-009 & & Anti-aircraft site & Late Historic & $92-600-028$ \\
\hline HT-93-010 & & Military & Late Historic & $92-600-028$ \\
\hline HT-93-011 & & Anti-aircraft gun location & Late Historic & $92-600-028$ \\
\hline HT-93-012 & & Anti-aircraft artillery & Late Historic & $92-600-028$ \\
\hline HT-93-013 & & $\begin{array}{l}\text { Anti-aircraft-Nike } \\
\text { Missile control }\end{array}$ & Late Historic & $92-600-028$ \\
\hline HT-93-014 & & $\begin{array}{l}\text { Radar site for Nike } \\
\text { Missile battery }\end{array}$ & Late Historic & $92-600-028$ \\
\hline HT-93-015 & & $\begin{array}{l}\text { Nike Missile base } \\
\text { Launch pad }\end{array}$ & Late Historic & $92-600-028$ \\
\hline HT-93-016 & & $\begin{array}{l}\text { Nike Missile control } \\
\text { center-Battery A }\end{array}$ & Late Historic & $92-600-028$ \\
\hline HT-93-017 & & Nike Missile Base & Late Historic & $92-600-028$ \\
\hline HT-93-018 & & Nike Missile Launch & Late Historic & $92-600-028$ \\
\hline HT-93-019 & & Military debris scatter & Late Historic & $92-600-028$ \\
\hline HT-93-020 & & $\begin{array}{l}\text { Nike Missile control } \\
\text { center-Battery B }\end{array}$ & Late Historic & $92-600-028$ \\
\hline HT-93-021 & & Military dump & Late Historic & $92-600-028$ \\
\hline HT-93-022 & & Military radar site & Late Historic & $92-600-028$ \\
\hline HT-93-023 & & Military dump site & Late Historic & $92-600-028$ \\
\hline HT-93-024 & & $\begin{array}{l}\text { Military observation } \\
\text { point }\end{array}$ & Late Historic & $92-600-028$ \\
\hline
\end{tabular}


Table 2.3. (Contd)

\begin{tabular}{|c|c|c|c|c|}
\hline $\begin{array}{l}\text { HCRL Temp. } \\
\text { Number }\end{array}$ & $\begin{array}{l}\text { Washington } \\
\text { Number }\end{array}$ & Site Type & Category & Project Number \\
\hline HT-93-025 & & $\begin{array}{l}\text { Military ammunition } \\
\text { storage }\end{array}$ & Late Historic & $92-600-028$ \\
\hline HT-93-026 & & Military debris dump & Late Historic & $92-600-028$ \\
\hline HT-93-027 & & Dump & Historic & 91-100-CERCLA \\
\hline HT-93-028 & & Homestead & Historic & 91-100-CERCLA \\
\hline HT-93-029 & & Homestead & Historic & 91-100-CERCLA \\
\hline HT-93-030 & & Homestead & Historic & 91-100-CERCLA \\
\hline HT-93-031 & & Homestead & Historic & 91-100-CERCLA \\
\hline HT-93-032 & & Homestead & Historic & 91-100-CERCLA \\
\hline HT-93-033 & & Homestead & Historic & 91-100-CERCLA \\
\hline HT-93-034 & & Homestead & Historic & 91-100-CERCLA \\
\hline HT-93-035 & & Homestead & Historic & 91-100-CERCLA \\
\hline HT-93-036 & & Homestead & Historic & 91-100-CERCLA \\
\hline HT-93-037 & & Depressions & Historic & 91-100-CERCLA \\
\hline HT-93-038 & & Homestead & Historic & 91-100-CERCLA \\
\hline HT-93-039 & & Homestead & Historic & 91-100-CERCLA \\
\hline HT-93-040 & & Dump & Historic & 91-100-CERCLA \\
\hline HT-93-041 & & Dump & Historic & 91-100-CERCLA \\
\hline HT-93-043 & & Homestead & Historic & 91-100-CERCLA \\
\hline HT-93-044 & $3-126$ & Gas Well/Cistern & Historic & $93-600-042$ \\
\hline HT-93-045 & $3-127$ & Gas well/Cistern & Historic & $93-600-042$ \\
\hline HT-93-046 & $3-131$ & Well/Cisterns & Historic & $93-600-042$ \\
\hline HT-93-047 & $3-133$ & Cistern & Historic & $93-600-042$ \\
\hline HT-93-048 & $3-135$ & Gas well/ Cistern/ Flake & $\begin{array}{l}\text { Historic/ } \\
\text { Prehistoric }\end{array}$ & $93-600-042$ \\
\hline HT-93-049 & $3-136$ & Well & Historic & $93-600-042$ \\
\hline HT-93-050 & & Homestead & Historic & 91-100-CERCLA \\
\hline HT-93-051 & & Dump & Historic & 91-100-CERCLA \\
\hline HT-93-052 & & Concrete blocks & Historic & 91-100-CERCLA \\
\hline HT-93-053 & & Homestead & Historic & 91-100-CERCLA \\
\hline HT-93-054 & & Dump & Historic & 91-100-CERCLA \\
\hline HT-93-055 & & Dump & Historic & 91-100-CERCLA \\
\hline
\end{tabular}


Table 2.3. (Contd)

\begin{tabular}{||l|l|l|l|l||}
\hline $\begin{array}{c}\text { HCRL Temp. } \\
\text { Number }\end{array}$ & $\begin{array}{c}\text { Washington } \\
\text { Number }\end{array}$ & \multicolumn{1}{|c|}{ Site Type } & \multicolumn{1}{c||}{ Category } & \multicolumn{1}{c||}{ Project Number } \\
\hline HT-93-056 & & Homestead & Historic & $91-100-$ CERCLA \\
\hline HT-93-057 & & Homestead & Historic & $91-100$-CERCLA \\
\hline HT-93-058 & & Orchard & Historic & $91-100$-CERCLA \\
\hline HT-93-059 & & Dump & Historic & 91-100-CERCLA \\
\hline HT-93-060 & & Homestead & Historic & $91-100-$ CERCLA \\
\hline HT-93-061 & $3-123$ & Well/Cistern & Historic & $93-600-042$ \\
\hline HT-93-062 & $3-124$ & Well/Cistern & Historic & $93-600-042$ \\
\hline HT-93-063 & $3-125$ & Gas well & Historic & $93-600-042$ \\
\hline HT-93-064 & & Gas well & Historic & $93-600-042$ \\
\hline HT-93-065 & $3-129$ & Gas well & Historic & $93-600-042$ \\
\hline HT-93-066 & $3-130$ & Lithic scatter/ & $\begin{array}{l}\text { Prehistoric/ } \\
\text { Historic }\end{array}$ & $93-600-042$ \\
\hline GT-93-067 & $3-132$ & Gas well & Historic & $93-600-042$ \\
\hline HT-93-068 & $3-134$ & Gas well & Historic & $93-600-042$ \\
\hline HT-93-069 & $3-137$ & Gas well & Historic & $93-600-042$ \\
\hline HT-93-070 & $3-139$ & Gas well & Historic & $93-600-042$ \\
\hline HT-93-071 & $3-140$ & Gas well & Historic & $93-600-042$ \\
\hline HT-93-072 & $3-141$ & Gas well & Historic & $93-600-042$ \\
\hline HT-93-073 & $3-142$ & Gas well & Historic & $93-600-042$ \\
\hline HT-93-074 & $3-138$ & Lithic scatter/ & $\begin{array}{l}\text { Prehistoric/ } \\
\text { Gistoric }\end{array}$ & $93-600-042$ \\
\hline HT-93-075 & $3-143$ & Lithic scatter & Prehistoric & $93-600-042$ \\
\hline HT-93-076 & $3-147$ & Lithic scatter/ & $\begin{array}{l}\text { Prehistoric/ } \\
\text { Historic }\end{array}$ & $93-600-042$ \\
\hline HT-93-077 & $3-148$ & Foundation & Historic & $93-600-042$ \\
\hline HT-93-078 & $3-149$ & Gas well & Historic & $93-600-042$ \\
\hline HT-93-080 & & $\begin{array}{l}\text { Lithics/tooth } \\
\text { enamel/Historic trash }\end{array}$ & $\begin{array}{l}\text { Prehistoric/ } \\
\text { Historic }\end{array}$ & $93-200-001$ \\
\hline HT-93-081 & & Trash scatter & Historic & $93-200-001$ \\
\hline HT-93-083 & & Wood frame structure & Historic & $93-200-001$ \\
\hline HT-93-084 & & Stove/Trash scatter & Historic & $93-200-001$ \\
\hline HT-93-085 & & Domestic scatter & Historic & $91-300-024$ \\
\hline
\end{tabular}


Table 2.3. (Contd)

\begin{tabular}{||l|l|l|l|l||}
\hline $\begin{array}{c}\text { HCRL Temp. } \\
\text { Number }\end{array}$ & $\begin{array}{c}\text { Washington } \\
\text { Number }\end{array}$ & \multicolumn{1}{|c|}{ Site Type } & \multicolumn{1}{c||}{ Category } & \multicolumn{1}{|c||}{ Project Number } \\
\hline HT-93-087. & $3-144$ & Lithic scatter & Prehistoric & $93-600-042$ \\
\hline HT-93-088 & $3-145$ & Gas well & Historic & $93-600-042$ \\
\hline HT-93-089 & $3-146$ & Gas well & Historic & $93-600-042$ \\
\hline $\begin{array}{l}\text { HP-93-001 } \\
\text { (Paleontologic } \\
\text { site) }\end{array}$ & & Tooth enamel & Undet. & $93-200-001$ \\
\hline
\end{tabular}

27 sites were recorded by the U.S. Army Corps of Engineers for the Arid Lands Ecology (ALE) project. The majority of the sites are historic, dating from the late 1800s to the Cold War Era. The early historic sites may yield new information on early Euro-American ranching and settlement activities in the Hanford area, and the later sites may reveal information concerning Hanford Site activities during the early Cold War Era. The prehistoric sites recorded this year may provide additional information about past resource use and subsistence patterns.

\subsection{ERDF Survey, North Slope Site Recordation, and 100 Area Operable Unit Site Recordation}

Three large projects were undertaken in FY 1993: ERDF, the North Slope Waste Sites, and the 100-HR-3 Operable Unit. Fifty-three archaeological sites and nine isolated finds were recorded during these three projects. Most of the finds are historic and present information ranging from lifeways of early settlers in the Hanford area to military installations in the 1950s (see Figure 2.1).

\subsubsection{Environmental Restoration Disposal Facility}

The ERDF will provide the disposal site for the waste exhumed during the Hanford Site Comprehensive Environmental Response, Compensation, and Liability Act (CERCLA) and Resource Conservation and Recovery Act (RCRA) cleanup actions. An area measuring approximately $11.0 \mathrm{~km}^{2}$ was surveyed between July 21 and September 10, 1993. A previous survey in the proposed project area identified one prehistoric isolated artifact (HI-89-016), a cobble tool. Nine isolated artifacts, three prehistoric and six historic, and five sites, one paleontologic, one prehistoric/historic, and three historic, were recorded in the area surveyed in the summer of 1993. Three of the sites do not meet the criteria for eligibility for the NRHP. The two other sites may be considered regionally or locally significant when viewed in the broad historic context of Euro-American ranching in southeastern Washington. However, the project should have no effect on these sites given the most recently proposed site boundaries. 


\subsubsection{The North Slope Waste Sites}

The North Slope Waste Sites project will clean up 39 sites located on the North Slope area of the Hanford Site. Between September 1992 and July 1993, 29 of the sites were recorded. Eight historic cistern sites were recorded in FY 1992. All of the sites recorded in FY 1993 were military installations constructed between the 1940s and 1960 . None of the military sites recorded meet the criteria for eligibility for the NRHP. Of the eight cistern sites recorded in FY 1992, five were determined to be potentially eligible for the NRHP. The work proposed for the cisterns is to backfill them, which will have no adverse effect on the cisterns.

\subsubsection{The 100 Area Operable Unit}

The northern portion of the 100 HR-3 Operable Unit was surveyed during the 1992 field season using 20 meter transects. The survey methodology used during the 1992 field season was modified for the FY 1993 survey of the southern portion of the operable unit. Since the FY 1992 survey substantiated 1941 aerial photograph evidence of structure locations and complexes encountered during the intensive survey effort, historic 1941 aerial photographs of the southern portion of the operable unit were studied to identify structures, features and other anomalies within the project area delineated for FY 1993. Using this information, 52 locations were selected for field investigation during FY 1993. Of these 52 locations, 27 were recorded as historic sites; 18 were farmsteads with foundations; seven were possible homesteads or farmsteads with few if any features remaining; one was a concrete block dump site; and one was a large circular depression. These sites represent the early Euro-American settlement period, the Depression era, and a more recent military presence on the Hanford Site. All work was completed by HCRL staff assisted by Northwest Organization of Colleges and Universities for Science (NORCUS) interns and AScI technicians. 


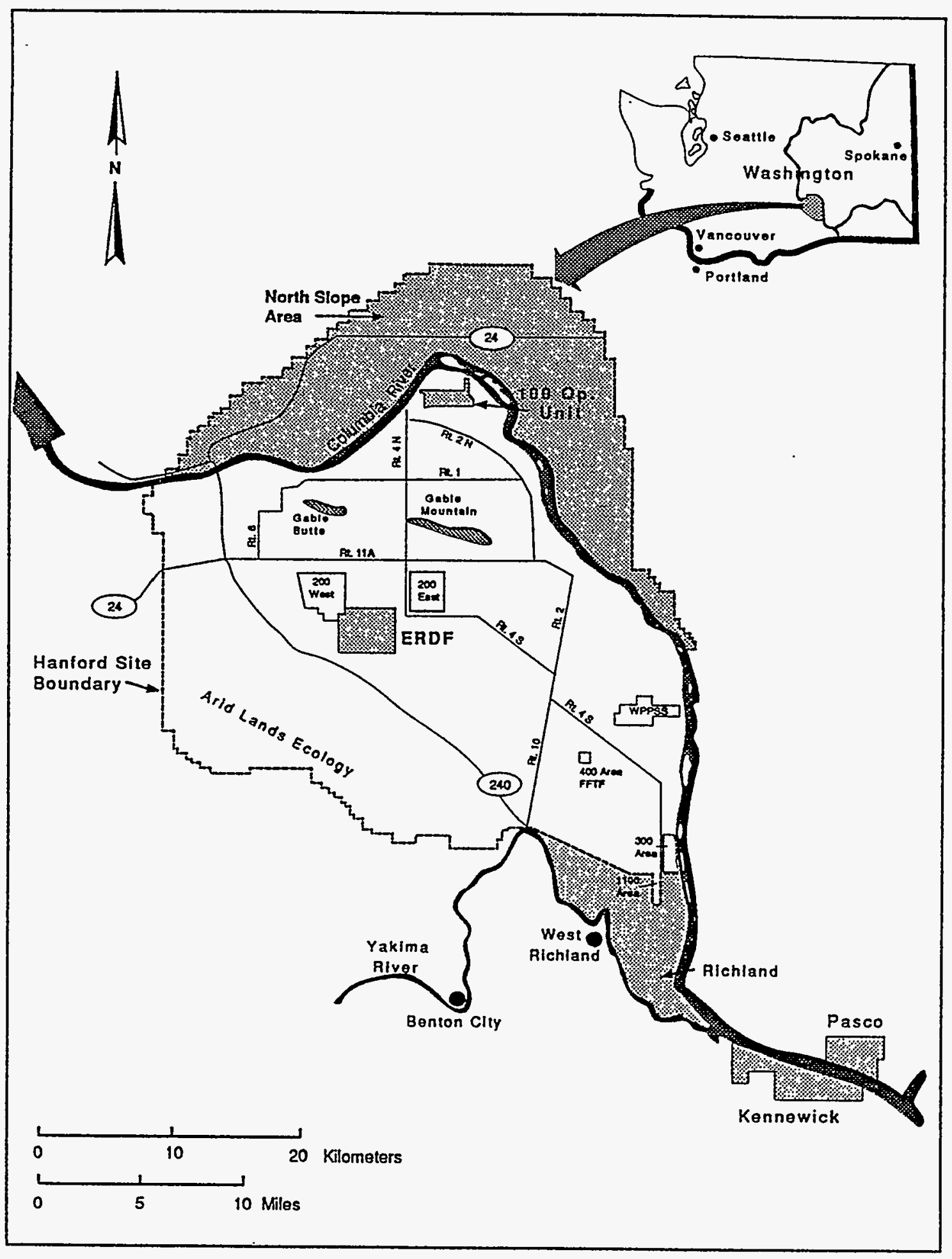

Figure 2.1. Survey/Site Recordation Areas for the ERDF, $100 \mathrm{HR}-3$ Operable Unit, and North Slope Waste Sites 


\subsection{The Monitoring Program}

As manager of the Hanford Site, the DOE-RL is assigned the stewardship of all onsite archaeological resources, traditional-use areas, paleontological deposits, and historic period properties. The DOE-RL, therefore, has the responsibility for determining whether its management and protection policies are effective and when they are inadequate. To determine the impact of DOE-RL policies and to safeguard cultural resources from destruction by natural processes or unauthorized excavation and collection, the HCRL maintains a monitoring program (Chatters 1989). As written in the HCRMP, the monitoring program requires the inspection of all cemetery sites at least once a year; inspection of sites listed on the NRHP at least every three years, and inspection of each site not listed on the NRHP at least every five years. Sites found to be adversely impacted, especially by unauthorized collection activity, are inspected annually.

For the 1993 monitoring cycle, 40 prehistoric sites were chosen for inspection, including 27 sites listed on the NRHP or the State Register of Historic Places. Sixteen of these were cemetery sites including sites where burials are suspected. Eleven sites were chosen because of their vulnerability to unauthorized collection, as evidenced from recent collector activities noted during previous site visits. Anthropogenic disturbance had also been observed at four cemetery sites during previous site visits. The 13 remaining sites chosen were either first-time visits to previously recorded sites (three listed on the NRHP and five not listed) or revisits to previously monitored sites listed on the NRHP (five sites). $A$ list of the sites monitored and a summary of the findings are provided in Table 3.1. More detailed descriptions of findings and recommendations for most of the sites can be found in Appendix $\mathrm{C}$.

\subsection{Cemetery Sites}

Cemetery sites are monitored annually to check for any adverse impacts such as vandalism, collector digging, wind and bank erosion, or other natural or anthropogenic disturbances. Annual visits provide a continuing record of any change in site integrity, and provide information that is helpful in determining the most effective surveillance for site management and protection. 
Table 3.1. Summary of Sites Monitored During 1993

\begin{tabular}{|c|c|c|c|c|c|c|c|c|c|c|c|}
\hline \multirow[b]{2}{*}{ Site } & \multirow[b]{2}{*}{$\begin{array}{l}\text { National/State } \\
\text { Register } \\
\text { Evaluation }\end{array}$} & \multirow[b]{2}{*}{$\begin{array}{c}\text { Date } \\
\text { Monitored }\end{array}$} & \multicolumn{9}{|c|}{ Disturbance* } \\
\hline & & & $\begin{array}{l}\text { No Recent } \\
\text { Disturbance } \\
\text { Recognized }\end{array}$ & $\begin{array}{l}\text { Collector } \\
\text { Digging }\end{array}$ & $\begin{array}{l}\text { Surface } \\
\text { Collection } \\
\text { Suspected }\end{array}$ & $\begin{array}{l}\text { Off-road } \\
\text { Vehicle } \\
\text { Traffic }\end{array}$ & Firebreak & $\begin{array}{c}\text { Stock } \\
\text { Damage }\end{array}$ & $\begin{array}{l}\text { Wind } \\
\text { Erosion }\end{array}$ & $\begin{array}{c}\text { Bank } \\
\text { Erosion }\end{array}$ & Other \\
\hline 45BN90 & Eligible & $9 / 27 / 93$ & & & & & & & & & \\
\hline 45BN104 & Unevaluated & $9 / 27 / 93$ & & & & & & & & & \\
\hline 45BN110 & Listed on NR & $10 / 4 / 93$ & & & & & & & & ४. & \\
\hline 45BN119 & Listed on NR & $10 / 13 / 93$ & & & . & & & & & & \\
\hline 45BN124 & Listed on NR & 9/21/93 & ל. & & & & & & & & \\
\hline 45BN125 & Listed on NR & $9 / 21 / 93$ & 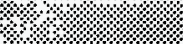 & & & & & & & & \\
\hline 45BN128 & Listed on NR & 10/13/93 & & & & & & & & & \\
\hline 45BN129 & Listed on NR & $11 / 2 / 93$ & & & & & & & & & \\
\hline $45 \mathrm{BN} 130$ & Listed on NR & $11 / 2 / 93$ & & & & & & & & & \\
\hline 45BN131 & Listed on NR & $10 / 4 / 93$ & & & & & & & & & \\
\hline 45BN139 & Listed on NR & $11 / 3 / 93$ & & & & & & & & & \\
\hline 45BN140 & Listed on NR & $11 / 3 / 93$ & & & \% & & & & & & \\
\hline 45BN142 & Listed on SR & $11 / 3 / 93$ & & & & & & & & Writon & \\
\hline 45BN143 & Listed on SR & $11 / 3 / 93$ & & & & & & & & & \\
\hline 45BN145 & Listed on SR & $10 / 28 / 93$ & & & & & & & & & \\
\hline 45BN150 & Listed on NR & $10 / 28 / 93$ & & & & & & & & & \\
\hline $45 \mathrm{BN} 151$ & Listed on NR & $9 / 27 / 93$ & & & & 3 & & & & & \\
\hline 45BN157A & Eligible & $10 / 29 / 93$ & & 3. & 1.1 & & & & & & \\
\hline 45BN157B & Eligible & 9/17/93 & & & & & & & & & \\
\hline 45BN173 & Listed on NR & 9/15/93 & 19. & & & & & & & & \\
\hline 45BN178 & Listed on NR & 9/28/93 & & & & ^. & & & 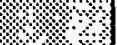 & & \\
\hline 45BN424 & $\begin{array}{l}\text { Unevaluated/ } \\
\text { eligible }\end{array}$ & 9/27/93 & & & & & & & & & \\
\hline
\end{tabular}


Table 3.1. (Contd)

\begin{tabular}{|c|c|c|c|c|c|c|c|c|c|c|c|}
\hline \multirow[b]{2}{*}{ Site } & \multirow[b]{2}{*}{$\begin{array}{l}\text { National/State } \\
\text { Register } \\
\text { Evaluation }\end{array}$} & \multirow[b]{2}{*}{$\begin{array}{c}\text { Date } \\
\text { Monitored }\end{array}$} & \multicolumn{9}{|c|}{ Disturbance* } \\
\hline & & & \begin{tabular}{c|} 
No Recent \\
Disturbance \\
Recognized
\end{tabular} & $\begin{array}{l}\text { Collector } \\
\text { Digging }\end{array}$ & \begin{tabular}{|c|} 
Surface \\
Collection \\
Suspected
\end{tabular} & $\begin{array}{l}\text { Off-road } \\
\text { Vehicle } \\
\text { Traffic }\end{array}$ & Firebreak & $\begin{array}{c}\text { Stock } \\
\text { Damage }\end{array}$ & $\begin{array}{c}\text { Wind } \\
\text { Erosion }\end{array}$ & $\begin{array}{c}\text { Bank } \\
\text { Erosion }\end{array}$ & Other \\
\hline 45BN427 & Unevaluated & 9/28/93 & & & & & & & & & Damage to \\
\hline 45FR258 & Listed on NR & $10 / 4 / 93$ & & 18 & & & & & $4=$ & & \\
\hline 45FR260 & \begin{tabular}{|l} 
Listed on NR \\
\end{tabular} & $10 / 4 / 93$ & 2 & & & & & & m nion: & & \\
\hline 45FR265 & Unevaluated & $10 / 29 / 93$ & & & & & & & & 8 & \\
\hline 45FR266 & Unevaluated & $10 / 29 / 93$ & & & & & & & & & I Ister \\
\hline 45GR302A & Listed on NR & $111 / 2 / 93$ & & 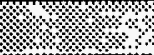 & 1 & & & & & $\because \geq$ & \\
\hline $45 \mathrm{GR} 302 \mathrm{C}$ & Listed on NR & $11 / 2 / 93$ & & & & & & & & & \\
\hline 45 GR303 & $\begin{array}{l}\text { Listed on NR } \\
\end{array}$ & $111 / 2 / 93$ & & & & & & & & & \\
\hline 45GR304 & Listed on NR & $11 / 2 / 93$ & & & & & & & & "1. & \\
\hline $45 \mathrm{GR} 306 \mathrm{~A}$ & Listed on SR & $11 / 3 / 93$ & & & & & & & $17=1$ & & \\
\hline 45GR306B & Listed on SR & $11 / 3 / 93$ & & 19 & 8 & & & & 4 & & \\
\hline $45 \mathrm{GR} 306 \mathrm{C}$ & Listed on SR & $11 / 3 / 93$ & & & & & & & & & \\
\hline 45GR307 & Unevaluated & $11 / 3 / 93$ & & & & & & & & & \\
\hline 45GR315 & Unevaluated & $11 / 4 / 93$ & & $2 ?$ & & & & & 18 & & \\
\hline 45GR317 & Listed on NR & $111 / 4 / 93$ & 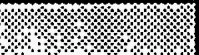 & & & & & & & & \\
\hline 45GR319 & Unevaluated & 9/17/93 & 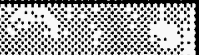 & & & & & & & & \\
\hline 45 GR619 & Unevaluated & $7 / 12 / 93$ & 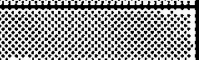 & & & & & & & & \\
\hline HT-87-019 & Eligible & 9/17/93 & $4=19$ & & & & & & & & \\
\hline 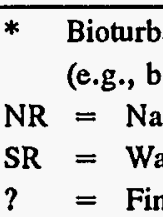 & $\begin{array}{l}\text { on also occurs at a } \\
k \text { swallows), and } \\
\text { nal Register of Hi } \\
\text { ington State Regis } \\
\text { ngs uncertain. }\end{array}$ & $\begin{array}{l}\text { sites to greater } \\
\text { ame trails are co } \\
\text { toric Places } \\
\text { er }\end{array}$ & $\begin{array}{l}\text { or lesser degree } \\
\text { nmon natural di }\end{array}$ & & $\begin{array}{l}\text { ind diggin } \\
\text { ed by wild }\end{array}$ & $\begin{array}{l}\text { large and } \\
\text { uimals. }\end{array}$ & & & & & and birds \\
\hline
\end{tabular}


Wanapum Indian leaders have identified eight cemeteries on the Hanford Site. Eight other cemeteries or suspected burial sites have been recorded as a result of archaeological evidence, field work, and literature searches. All of these areas were monitored during FY 1993.

Disturbances at cemetery sites or where burial sites are suspected included collector digging, surface collection, off-road vehicle traffic, stock damage, wind erosion, and bank erosion. No recent anthropogenic disturbance or natural erosion was seen at (see Table 3.1) 45GR317, 45BN124, 45BN125, and HT-87-019, which all appeared in good condition. Collector digging was found on the beach at 45FR258. Collector digging was also identified at 45GR306B adjacent to 45GR306A and 45GR306C. Surface collection was suspected at three sites, 45BN157B, 45FR258, and 45GR306A. Off-road vehicle tracks were found at 45BN151 and 45GR306A, and vehicle tracks went to the base of 45BN427, where vandalism to the landform had occurred. Stock had damaged the periphery of 45BN157B. Minor bank erosion was seen at 45BN142. Wind erosion continues to be the dominant factor destroying site integrity. Deflation was recorded at 45BN128, 45BN139, 45BN143, 45BN157B, 45GR306A, 45GR306C, 45GR302C, and 45FR258. Erosion was severe enough to expose human remains at four of these cemeteries, 45BN128, 45BN143, 45GR306A, and 45GR306C.

\subsection{Sites Listed on the National or State Register of Historic Places}

Fourteen of the monitored sites; other than cemeteries, are listed on the National (NRHP) or State Register of Historic Places. Registered sites are managed so that characteristics making them eligible for listing on the National or State Register are not adversely affected (36 CFR 800.9). Sites in this category were inspected for evidence of vandalism and other disturbances. If the site had not been previously monitored, the appropriateness of the original site descriptions and locations was also evaluated. In all cases, except 45BN427, the original site descriptions were inadequate. Lacking were site maps, complete descriptions of artifacts and features, legal descriptions, and photographs. Each site in this category, except $45 B N 427$, requires an updated site form.

Three of the sites had not been inspected since their initial recording in 1968: 45BN150, 45GR303, and 45GR304. All sites were larger than initially recorded (see Appendix C). Site 45BN150 was in good condition with only minor erosion from natural processes. Sites 45 GR 303 and 45GR304 are undergoing severe bank erosion which is being exacerbated by the frequent river fluctuations as a result of dam operations.

Three sites monitored this cycle were last visited in 1989: 45BN145, 45BN178, and 45FR260. Site 45BN145 was in good condition with no recent disturbances. Only minor natural wind erosion has occurred at 45FR260, where the vegetation is recovering since the removal of the stock and the last site inspection. Wind continues to erode 45BN178, exposing artifacts and features. Surface collection by Hanford Site workers is a continuing problem at this site, where fresh vehicle tracks and footprints were observed the day of our inspection. 
Four sites were last monitored in 1990: 45BN110, 45BN130, 45BN131, and 45BN173. No recent disturbances had occurred at 45BN173. Severe bank slumping is adversely affecting the site integrity at $45 \mathrm{BN} 110$ and $45 \mathrm{BN} 130$. This slumping is also the result of fluctuating river levels. Collector digging continues to occur at $45 \mathrm{BN} 131$.

Two sites, 45BN1 19 and 45GR302A, were last monitored in 1991. Wind erosion is eroding part of 45BN119. Surface collection and collector digging continues to occur at 45GR302A along the beach.

Two sites, 45BN140 and 45GR306B, were last monitored in 1992. Wind erosion continues to defiate 45BN140. Off-road vehicle tracks were observed and surface collection may be occurring at this site. Site 45GR306B has undergone the most severe vandalism seen this year. Over 80 hand dug pits were found in three areas of the site on the terrace over $50 \mathrm{~m}$ from the river. These pits had been made within the last year. These appeared to have been dug over successive trips to the site as some appeared less eroded than others. The holes, which measured 20 to $40 \mathrm{~cm}$ in diameter and 10 to $30 \mathrm{~cm}$ deep, were dug with a tined tool. The pits were dug in a broad swale which would have hidden the collectors from view. The site is a popular stopping spot for recreationists. Recent trash, fire rings, and rock piles for fishing poles were found within the site boundary. Other disturbance includes recent vehicle tracks and wind erosion. Surface collection is suspected because of the absence of formed tools and the vandalism at the site.

\subsection{Sites Not Listed on the National Register of Historic Places}

Ten sites selected for the FY 1993 monitoring cycle fell into this category. Anthropogenic disturbance had been noted at half of these sites during previous monitoring trips: 45FR266 in 1990; 45GR315 in 1991; and 45BN90, 45BN104, and 45BN157A in 1992. Anthropogenic disturbances were again in evidence or suspected at all of these sites. At 45FR266, minor damage occurred to the site during construction of a levee. No request for cultural resource review had been made by the agency responsible for the action. Surface collection of artifacts is also occurring at this site. Collector digging is suspected at 45GR315. Surface collection is also suspected at 45BN104 which is also being severely damaged by downcutting of dirt roads. Site 45BN90 continues to be damaged by maintenance of a firebreak along the western edge of the site. Site 45BN157A continues to be damaged by human activity. The site is located at a popular public access camping and fishing spot, and collecting activities continue there as they have for many years. Off-road vehicles and stock damage are causing the natural erosive forces to have a more severe effect. A firebreak was also constructed through the site this summer.

This was the first recorded visit to five of the sites since they were initially recorded: 45FR265, 45GR307, and 45GR319 in 1968; 45GR619 in 1989; and 45BN424 in 1991. Some surface collection and bank erosion has occurred at 45FR265. Because of the thick vegetation cover, further work is needed at this site before an evaluation can be made. Site 45GR307 contains several features and 
artifact concentrations, and appears to contain stratified deposits. Further evaluation is needed at this site. Site 45GR319, as was initially described, could not be relocated. Further evaluation of this site is not recommended. Sites 45 GR619 and 45BN424 were unchanged since their initial recording, and no disturbance was recognized.

\subsection{Conclusions and Recommendations}

The observations made during the FY 1993 monitoring cycle replicate the findings of earlier monitoring inspections (Chatters et al. 1989, 1990, 1991, 1992). The same anthropogenic and natural forces are at work, often having adverse impacts on archaeological and cultural sites. Of the 40 sites examined during the FY 1993 monitoring cycle, 14 were damaged by anthropogenic causes. Eleven of these sites were also subjected to wind and/or bank erosion. Fourteen other sites were affected by natural erosive forces. Collector digging and surface collection can be managed by increased surveillance and seeking convictions under the ARPA. Collector digging may be accelerating as a result of the perceived decrease in security at the Hanford Site. An effective surveillance program needs to be established. Although annual monitoring of sites with evidence of vandalism has been effective for tracking damages, it has not been an effective deterrent. The Hanford Patrol has been effective in recovering some artifacts taken by unauthorized collectors; however, no ARPA convictions have been made.

Those sites found to be suffering the most damage are in areas accessible to the public, by either road or boat, or in Franklin and Grant counties, where surveillance is perceived to be less frequent. To deter damage to sites by the general public and to help obtain an ARPA conviction, prominent and detailed signs should be installed at all boat launches, both formal and informal, along the Hanford Reach. These signs should detail the laws protecting sites and the penalties associated with these laws. Similar signs should also be placed along roads at entry points to the Hanford Site.

Education programs concerning the laws protecting cultural resources and penalties associated with these laws should continue to evolve for both the general public and Hanford workers. Surface collection seems to be the most common offense. The potential for this activity to accelerate is great with the new Hanford mission and the resulting increase in activity in areas with archaeological and cemetery sites. Disciplinary action taken against any offender caught might be an effective deterrent to others.

Additional protective measures include limiting access, removal of stock, and assuring that all proposed projects include a NHPA Section 106 compliance review. The damage caused by natural erosive forces can be lessened by revegetation and bank stabilization. 


\subsection{The Inventory Program}

Along with all other federal agencies, DOE-RL is required by the ARPA and resulting regulations to provide the management, storage, and conservation of artifacts and records from lands that it manages, and to make them available to Native Americans and scientific research. This process is called "curation." The standards and guidelines for curation are iterated in 36 Code of Federal Regulations (CFR) Part 79, "Curation of Federally Owned and Administered Archaeological Collections."

The first steps to meet these standards were implemented in 1992 by HCRL by identifying space and the acquisition of shelving to meet the standards set forth in 36 CFR Part 79. In 1993, five collections from excavations that had been conducted on the Hanford Site and stored at other locations were retrieved, including 45BN157a, held by Kenneth DenBeste, and collections from test excavations at 45BN149, 45GR302a, 45GR306b, and 45GR317 from Kim Simmons, Director, Mid-Columbia Archaeological Society (MCAS). In addition, the collection resulting from the 1968 Benton-Franklin Survey conducted by Dr. David Rice was retrieved from the MCAS.

At the present time, 43 collections are being housed at the HCRL. A summary of the collections has been forwarded to DOE in compliance with the NAGPRA requirements (see 4.1). The inventory of four collections has been completed and the remaining collections will be inventoried by 1995 as mandated by NAGPRA.

\subsection{NAGPRA Summary}

The HCRL is presently housing 14 collections resulting from projects carried out by the HCRL staff and field schools conducted in conjunction with the HCRL. Also housed at the HCRL are 29 collections recovered during projects completed by the MCAS under the direction of Dr. David Rice. These collections are in the process of being stabilized and therefore no complete inventory of artifacts is available at this time. In addition to the 43 collections that are being housed at the HCRL, additional collections are currently being housed at the University of Idaho.

45BN090 (Collection is housed at the HCRL).

The Washington State Department of Fisheries was considering this area for a boat launch, and therefore an evaluation of this site was required. Shell and undeterminable and/or unanalyzed bone fragments, chipped stone, projectile points, fire-cracked rock, and stone tools were recovered from test units. 
45BN108 (Collection is housed at the HCRL).

Eight artifacts were collected from this housepit site. The artifacts and corresponding field sheets are on file. Verification that all artifacts listed on the field sheets are included in the collection will be made when the inventory has been completed by the HCRL staff.

45BN110 (Collection is housed at the HCRL).

One artifact was collected from this open campsite during a survey. The artifact and corresponding field sheet are on file. Curation has been completed by the HCRL staff.

45BN118 (Collection is housed at the HCRL).

Shell was collected from a borrow pit near site 45BN118 for study.

45BN119 (Collection is housed at the HCRL).

Two artifacts were collected from this open campsite during a survey. The artifacts and corresponding field sheets are on file. Verification that all artifacts listed on the field sheets are included in the collection will be made when the inventory has been completed by HCRL staff.

45BN120 (Collection is housed at the HCRL).

This open campsite was recorded and 1 artifact was collected during a survey. The artifact and corresponding field sheet is on file. Curation has been completed by HCRL staff.

45BN121 (Collection is housed at the HCRL).

This housepit site was recorded and eight artifacts were collected during a survey. The artifacts and corresponding field sheets are on file. Verification that all artifacts listed on the field sheets are included in the collection will be made when the inventory has been completed by HCRL staff.

45BN125 (Collection is housed at the HCRL).

This site, which contains burial cairns and housepits, was recorded and 16 artifacts were collected during a survey.

The artifacts and corresponding field sheets are on file. Verification that all artifacts listed on the field sheets are included in the collection will be made when the inventory has been completed by HCRL staff.

45BN131 (Collection is housed at the HCRL).

This open campsite was recorded and two artifacts were collected during a survey. The artifacts and corresponding field sheets are on file. Verification that all artifacts listed on the field sheets are included in the collection will be made when the inventory has been completed by HCRL staff. 
45BN136 (Collection is housed at the HCRL).

Twenty artifacts were collected from this campsite during a survey. The artifacts and corresponding field sheets are on file. Verification that all artifacts listed on the field sheets are included in the collection will be made when the inventory has been completed by HCRL staff.

45BN140 (Collection is housed at the HCRL).

This campsite was recorded and three artifacts were collected during a survey. The artifacts and corresponding field sheets are on file. Verification that all artifacts listed on the field sheets are included in the collection will be made when curation has been completed by HCRL staff.

45BN143 (Collection is housed at the HCRL).

Fifteen artifacts were collected from this cemetery site during a survey.

The artifacts and corresponding field sheets are on file. Verification that all artifacts listed on the field sheets are included in the collection will be made when the inventory has been completed by HCRL staff.

45BN145 (Collection is housed at the HCRL).

One artifact was collected from this campsite during a survey. The artifact and corresponding field sheet are on file. Verification that the artifact listed on the field sheets is included in the collection will be made when the inventory has been completed by HCRL staff.

45BN146 (Collection is housed at the HCRL).

This housepit site was recorded and 10 artifacts were collected from it during a survey. The artifacts and corresponding field sheets are on file. Verification that all artifacts listed on the field sheets are included in the collection will be made when the inventory has been completed by HCRL staff.

45BN148 (Collection is housed at the HCRL).

One artifact was collected from this housepit site during a survey. The artifact and corresponding field sheets are on file. Verification that the artifact listed on the field sheet is included in the collection will be made when the inventory has been completed by HCRL staff.

45BN149 (Collection is housed at the HCRL).

During an excavation of this housepit site, 195 artifacts were collected. The artifacts and corresponding field sheets are on file. Verification that all artifacts listed on the field sheets are included in the collection will be made when the inventory has been completed by HCRL staff. 
45BN157A (Collection is housed at the HCRL).

An extensive excavation was conducted for U.S. Energy Research and Development Administration (ERDA) under the direction of Dr. Rice. This collection has recently been retrieved from the home of MCAS member Kenneth DenBeste and a complete inventory will be compiled and stabilization completed by HCRL staff.

45BN157B (Collection is housed at the HCRL).

During a survey, this cemetery and campsite were recorded and seven artifacts were collected.

The artifacts and corresponding field sheets are on file. Verification that all artifacts listed on the field sheets are included in the collection will be made when the inventory has been completed by HCRL staff.

45BN163 and 45BN164 (Collection is housed at the HCRL).

During 1992, these sites were tested to determine the necessity of mitigation for pending projects. A human clavicle fragment was recovered at 45BN163 in 1987 and is being held at the request of the Wanapum Tribe until it is repatriated and reburied. The remaining artifacts for these two sites consist of shell fragments, undeterminable and/or unanalyzed bone fragments, stone tools, and lithic debitage.

45BN179 and 45BN180 (Collection is housed at the University of Idaho.)

These sites were mitigated by Dr. Rice, University of Idaho, for the United Engineers and Constructors, Inc. Site $45 \mathrm{BN} 179$ contained 743 artifacts and $45 \mathrm{BN} 180$ contained 22 artifacts. This collection is curated and housed at the University of Idaho.

45BN257 (Collection is housed at the University of Idaho.)

Dr. Rice excavated this site to mitigate the impacts of a pending pump house construction project. The recovered items consist of 205 fire-cracked rocks, charcoal, shell and mammal bone fragments, three flakes, and three cobble tools.

45BN264 (Collection is housed at the HCRL).

Two artifacts were collected from this open campsite during a survey. The artifacts and corresponding field sheets are on file. Verification that all artifacts listed on the field sheets are included in the collection will be made when the inventory has been completed by HCRL staff. It must be noted that a site with this number is not included in Dr. Rice's report. It is possible that the field crew inadvertently identified a Franklin County site (FR) as a Benton County site (BN). Rice does include a site identified as 45FR264 in his report; however, there are no field sheets or artifacts identified with that number.

45BN266 (Collection is housed at the HCRL).

Dr. Rice completed a surface collection of this small lithic scatter. Lithic debitage and a projectile point fragment were recovered. 
45BN307 (Collection is housed at the HCRL).

A test excavation was conducted to evaluate this site for the proposed Skagit/Hanford Nuclear Power Project. Both historic and prehistoric artifacts were recovered. The prehistoric artifacts included projectile points, bifaces, net weights, a ground stone fragment, a battered cobble, and flakes.

45BN412 (Collection is housed at the HCRL).

Because this site is known to the public and was being looted on a regular basis, a controlled surface collection was conducted. Western Washington University field school and students in the DOE High School Student Honors Research Symposium were involved in this work. Items recovered and housed at HCRL include bison tooth enamel, undeterminable and/or unanalyzed bone fragments, stone tools, projectile points, shell, and fire-cracked rock.

45BN423 (Collection is housed at the HCRL).

In August 1992, it was determined that this site was at risk. Therefore, an excavation was completed to determine its eligibility for the NRHP. Stone tools, projectile points, shell and undeterminable and/or unanalyzed bone fragments, and lithic debitage were recovered.

45BN432 and 45BN433. (Collection is housed at the HCRL).

An excavation was carried out at these sites to determine their eligibility for the NRHP. Small lithic debitage, undeterminable and/or unanalyzed bone and shell fragments were recovered.

45BN447 (Collection is housed at the HCRL).

In August 1991, a test excavation was completed for an assessment of this site's scientific significance to comply with Section 106 of the NHPA. Mammal bone, debitage, fire-cracked rock and projectile points were recovered.

45BN480 (Collection is housed at the HCRL).

A survey was completed due to a pending project in the area. One site consisting of a historic can scatter and 11 historic isolates were located, collected, and stabilized.

45FR254 (Collection is housed at the HCRL).

Two artifacts were collected from this campsite during a survey. The artifacts and corresponding field sheets are on file. Verification that all artifacts listed on the field sheets are included in the collection will be made when the inventory has been completed by HCRL staff.

45FR257 (Collection is housed at the HCRL).

This campsite and potential burial site was recorded and two artifacts were collected from it during a survey. The artifacts and corresponding field sheets are on file. Verification that all artifacts listed on the field sheets are included in the collection will be made when the inventory has been completed by HCRL staff. 
45FR258 (Collection is housed at the HCRL).

One artifact was collected from this campsite during a survey. The artifact and corresponding field sheet are on file. Verification that the artifact listed on the field sheet is included in the collection will be made when the inventory has been completed by HCRL staff.

45FR259 (Collection is housed at the HCRL).

This campsite was recorded and one artifact was collected from it during a survey. The artifact and corresponding field sheet are on file. Verification that the artifact listed on the field sheet is included in the collection will be made when the inventory has been completed by HCRL staff.

45FR262 (Collection is housed at the HCRL).

Six artifacts were collected from this open campsite found during a survey. The artifacts and corresponding field sheets are on file. Verification that the artifacts listed on the field sheet is included in the collection will be made when the inventory has been completed by HCRL staff.

45FR266h (Collection is being housed at the University of Idaho.)

An archaeological assessment was requested by ERDA to meet its obligations for historic preservation. This was completed under the direction of Dr. Rice with students from the University of Idaho. The excavation resulted in a collection of 5,994 historic artifacts and 280 prehistoric artifacts. The prehistoric artifacts included mussel shells, chipped stone flakes, fire-cracked rocks, cobble choppers, a projectile point, and an undetermined item.

45FR267 (Collection is housed at the HCRL).

Although nine artifacts are listed and accounted for with this site number printed on them, the site is not mentioned in Dr. Rice's report. Site 45FR267 is located at the Connell Quarry. We feel that these artifacts may be mislabeled.

45GR301 (Collection is housed at the HCRL).

This open campsite was recorded and one artifact was collected during a survey. The artifact and corresponding field sheet are on file. Verification that the artifact listed on the field sheet is included in the collection will be made when curation has been completed by HCRL staff.

45GR302A (Collection is housed at the HCRL).

During an excavation of this housepit site, 1,154 artifacts were collected. The artifacts and corresponding field sheets are on file. Verification that the artifacts listed on the field sheets are included in the collection will be made when the inventory has been completed by HCRL staff.

45GR306 (Collection is housed at the HCRL).

A field school under the direction of Steve Hackenberger of Central Washington University, in conjunction with PNL, completed an excavation to evaluate this site. Artifacts recovered were chipped stone, tools, undeterminable and/or unanalyzed bone fragments, shell, fire-cracked rock, and projectile points. 
45GR306B (Collection is housed at the HCRL).

During an excavation of this housepit site/campsite, 349 artifacts were collected. The artifacts and corresponding field sheets are on file. Verification that the artifacts listed on the field sheets are included in the collection will be made when the inventory has been completed by HCRL staff.

45GR315 (Collection is housed at the HCRL).

Three artifacts were collected from this housepit/campsite during a survey. The artifacts and corresponding field sheets are on file. Verification that the artifacts listed on the field sheets are included in the collection will be made when the inventory has been completed by HCRL staff.

45GR316 (Collection is housed at the HCRL).

This campsite was recorded and three artifacts were collected from it during a survey. The artifacts and corresponding field sheets are on file. Verification that the artifacts listed on the field sheets are included in the collection will be made when the inventory has been completed by HCRL staff.

45GR317 (Collection is housed at the HCRL).

During an excavation of this cemetery and housepit/campsite, 30 artifacts were collected.

The artifacts and corresponding field sheets are on file. Verification that the artifacts listed on the field sheets are included in the collection will be made when the inventory has been completed by HCRL staff.

45GR318 (Collection is housed at the HCRL).

During an excavation of this campsite, 69 artifacts were collected. The artifacts and corresponding field sheets are on file. Verification that all artifacts listed on the field sheets are included in the collection will be made when an inventory has been completed by HCRL staff.

100-HR-3 Operable Unit (Collection is housed at the HCRL).

The HCRL staff and NORCUS students conducted a field survey of 100-HR-3 Operable Unit (600 Area). Sites were located and recorded. Diagnostic artifacts were collected to date sites.

During the summer of 1993, potential cultural resources sites in the project area were located using aerial photographs taken in 1941. Based on the presence of structures, features, and anomalies, sites were surveyed and recorded, and any diagnostic artifacts located were collected. All artifacts from this project are historic.

\section{Confiscated Items; Items With No Provenience}

A few artifacts have no known exact location; others were confiscated from collectors by the Hanford Patrol. The latter (uninventoried) include net weights, lithic debitage, a projectile point, awl fragments, and cobble tools. 


\subsection{The Public Education Program}

Education of the public, Hanford workers, and non-Hanford professionals is a key part of the Hanford Cultural Resources Project. The ARPA mandates dissemination of information about archaeology to instill in individuals the importance of archaeological and historic resources. Successful enforcement of that law also requires that violators be aware of the illegality of their actions. ARPA also specifies that the results of archaeological studies on public lands must be disseminated for use in scientific research by other professionals. In addition to legal mandates, DOE-RL wishes to publicize its activities. Finally, PNL is actively involved in the education programs of DOE-RL, providing research opportunities for high school, college, and graduate-level interns.

To fulfill its legal responsibilities and contribute to educational programs of DOE, the HCRL conducts educational activities on three fronts: 1) public presentations to organizations, schools, and the media; 2) involvement of student interns and teachers; and 3) publication and presentation of scientific findings to fellow professionals.

\subsection{Public Education}

Public education activities in FY 1993 consisted of lecturing to organizations and tours, giving interviews to regional news media, and participating in development of videos. Target populations were both the Hanford workforce and the public at large.

\subsubsection{Public Lectures}

Staff members made seven presentations to outside groups and organizations (see Appendix D). Topics ranged from NHPA Section 106 compliance processes to scientific advances made by studying the archaeology and history of the Columbia Basin and Hanford's cultural resources. Most presentations were requested by the recipient organizations, the most popular topic being the prehistory of Eastern Washington at various degrees of inclusiveness. One of the presentations was to Hanford Site staff. Each presentation stressed the cultural values of the Hanford Site.

\subsubsection{Media Exposure}

The HCRL was increasingly involved in media exposure in FY 1993. Reporters asked about a variety of topics, but were most interested in the methods and techniques used to survey, record, and evaluate cultural resources. The media were largely from the Tri-Cities, Washington. 


\subsubsection{Informational Videos}

Staff members took part in developing the scripts and footage for one video on the cultural resources of the Hanford Site which was produced by the Office of Hanford Environment. The documentary will be broadcast on public television and used in public schools as part of the DOE-RL public relations program. Two key issues stressed in this presentation are the importance of respecting Native American cultural interests and protecting archaeological resources.

\subsubsection{Displays}

Work on four stand-alone displays, a combination of text and pictures with three-dimensional objects, was a low priority during FY 1993. Work on these displays will continue throughout the 1994 fiscal year. The first display covers prehistory, introduces the HCRL, emphasizes ARPA, and requests help in protecting archaeological resources. The second display describes Native American life in the nineteenth and early twentieth centuries and emphasizes the importance of sacred places and traditional use areas. Pre-Hanford Euro-American history is addressed by the third display, which emphasizes the NHPA. The final unit highlights the Manhattan Project. When finished, the displays will be moved throughout the Hanford Site.

\subsection{Interns and Researchers}

DOE-RL funds a variety of programs for providing direct student and professional involvement in research at the Hanford Site. In FY 1993, the HCRL participated in the Teacher Research Associate Program (TRAC) and NORCUS. A total of four TRAC researchers were involved in research into past stream conditions using archaeological shell samples. Three NORCUS students were also involved in field and laboratory work for HCRL.

\subsection{Publications}

HCRL members were professionally active this fiscal year, publishing two technical reports and one journal article (Appendix D). Technical reports described large-scale archaeological surveys of the 100 areas and described HCRL activities in FY 1992. 


\subsection{NHPA Section 110 Survey}

The HCRMP specifies that the HCRL will conduct a $10 \%$ survey of the Hanford Site lands, the results of which will be used to devise a predictive model of archaeological site locations. This is an acceptable means of satisfying the requirement in Section 110 of the National Historic Preservation Act of 1966, which directs federal agencies to inventory the historic properties on their land holdings. This work was originally to be conducted over a period of six years, beginning in FY 1989. However, this work has consistently fallen below higher-priority effort. To date, only 784.04 ha or $0.578 \%$ of the Hanford Site has been surveyed in five years.

A stratified random sampling strategy has been used to select $10 \%\left(143 \mathrm{~km}^{2}\right)$ of Hanford Site lands for survey. Stratification was based on topography, surface hydrology, soils, and known distributions of archaeological resources; the strata are referred to as environmental zones. Once these zones had been defined, the entire site was divided into sample units of 16 hectares $\left(1 / 16 \mathrm{mi}^{2}\right)$, which were then numbered and sampled randomly for each environmental zone ${ }^{(a)}$. In FY 1993, no plots were surveyed due to staff and funding limitations.

(a) The stratification and sampling procedures are documented in: Hanford Cultural Resources Laboratory (HCRL) 1988. "Basalt Waste Isolation Project Archaeological and Cultural Resource Surveys." Letter Report from Hanford Cultural Resources Laboratory, Pacific Northwest Laboratory to U.S. Department of Energy, Richland, Washington. 


\subsection{Research Activities}

As a part of PNL, HCRL uses information from archaeological studies on the Hanford Site to advance knowledge. During FY 1993, staff members and research associates continued or initiated research in the areas of archaeology and climatic change.

\subsection{Archaeology}

Research in the field of archaeology focuses on three general areas of interest: interaction between prehistoric Native Americans and their plant and animal resources; early settlement patterns of EuroAmericans; and the private-to-public land transfer during the early 1940s for the Manhattan Project. The cultural interface between local Indian Tribes and settlers is an emerging interest we hope to pursue in the future.

\subsubsection{Human/Resource Interaction}

The Hanford Site, because it has been developed less than most of the surrounding Columbia Basin, contains a large number of sites and isolated artifacts associated with the procurement and processing of animal and plant resources. This provides an unequaled opportunity to investigate such issues as hunting and fishing strategies; fish and meat processing strategies; plant processing techniques and tools; the regional distribution of activities relating to procurement and processing of all sorts of living resources; and the evolution of resource exploitation strategies as they relate to settlement patterns, societal development, population densities, and climatic change. During FY 1993, additional data was gathered on fishing strategies at a site near the Columbia River. Preliminary testing at this site was conducted in response to proposed project activities associated with the Treated Effluent Disposal Facility which is located north of the 300 Area.

\subsubsection{Early Euro-American Settlement Patterns}

The first use of the Hanford Site by settlers was for cattle and horse pasturage. For much of the site, that use continued until Hanford was designated in 1943. Therefore, much of the historic archaeological record of the Hanford Site consists of herders' camps, ranches, and cisterns used by the cattlemen. Sites relating to this era were recorded in FY 1993 in the 100 Area and the Arid Lands Ecology Reserve (ALE) portion of the Hanford Site. On ALE, homesteads and/or small ranches were

recorded, some of them dating to the late nineteenth century. Research directions related to this period of time are still in the formulation stage. 


\subsubsection{Impacts of the Manhattan Project}

Prior to the establishment of the Hanford Site, people had settled into the small towns of White Bluffs, Hanford, and Richland and had established homes and farmsteads. When these private land holdings were transferred to the government in the early 1940s, many people were left homeless and the towns of White Bluffs and Hanford were abandoned. During surveys of the $100 \mathrm{HR}-3$ Operable Unit and the ERDF project, HCRL staff discovered numerous dumps and building foundations-in fact, entire cultural landscapes from this time period were observed. In the portion of the $100 \mathrm{HR}-3$ Operable Unit surveyed during FY 1993, many small farmsteads and other locations representing the military presence on the Hanford Site were recorded, the study of which could provide insights into the Depression. 


\subsection{Objectives For FY 1994}

Significant progress is anticipated for FY 1994 in the areas of NHPA Section 106 compliance, NHPA Section 110 compliance, data management curation, education, and research.

\subsection{NHPA Section 106 Compliance}

A draft Programmatic Agreement (PA) will be completed and submitted to DOE-RL during FY 1994. Several revisions of this document were completed during FY 1993. Such agreements are developed to make the Section 106 compliance process more efficient for federal agencies involved in large, complex projects or when many requests are required for classes of undertakings. Agencies can seek to develop a PA:

- when effects on historic properties are similar and repetitive or are multi-state or national in scope

- when effects on historic properties cannot be fully determined prior to approval

- when non-federal parties are delegated major decisionmaking responsibilities

- that involves development of regional or land-management plans

- that involves routine management activities at federal installations.

The final PA will be developed in consultation with DOE-RL, the Advisory Council, and the State Historic Preservation Officer. The Council and DOE-RL will seek public involvement by public announcement prior to the development of the final agreement. Invited views will be sought from Indian tribes, local interest groups, including state and local governments, and industries. Following consideration of the comments received from interested parties, the State Historic Preservation Officer, the Advisory Council and DOE-RL will execute the agreement. Other parties may sign the agreement as consulting parties if deemed appropriate. The approved PA will meet DOE-RL's NHPA

Section 106 compliance requirements for all undertakings carried out in accordance with the agreement and will provide the basis for the HCRMP (36 CFR 800.13).

Before the PA is complete, the number of requests for Section 106 reviews is expected to continue on a level similar to the second half of FY 1993, or approximately 35 to 45 per month. After the PA is complete, the incoming reviews should decrease dramatically to approximately fifteen to twenty per month. Building demolition and modification projects are anticipated to remain at a high level.

During FY 1994, the building demolition project requests from FY 1993 will be completed. The survey report for the ERDF and a monitoring plan for the permanent Environmental and Molecular Sciences Laboratory (EMSL) will also be completed. 
Monitoring of construction activities at the EMSL and the Treated Effluent Disposal Facility will be ongoing throughout FY 1994 until all construction is complete. Additional fieldwork will be performed for the 100 Area CERCLA project. More projects involving field work in the ALE and North Slope are anticipated in FY 1994. Other field work projects are difficult to predict, but, as in previous years, many small and a few large projects can be expected.

In FY 1994 the cultural resources reviews will be coordinated with ecological reviews, which are also handled by PNL personnel. With the new process, each requester will send two copies of each request for review to the HCRL staff, who will then transmit one copy to the staff who performs the ecological reviews. From then on, the requests will be handled by the two groups separately. This new method will streamline the process for those requesting reviews.

\subsection{NHPA Section 110 Compliance}

HCRL will focus on surveying in the ALE, particularly Rattlesnake Mountain, and reporting results of past test excavations. Plans for down-sizing the Hanford Site include divestiture of ALE and North Slope (Waluke Slope), an area for which we have little information about cultural resources. If these land parcels are exchanged and remain under federal jurisdiction in an agency other than DOERL, the cultural values will be managed in accordance with NHPA. Should these parcels not remain under federal jurisdiction, then an inventory of all historic properties (historic and archaeological properties that are eligible for the National Register) will be required before the land exchange can be completed. In anticipation, random sample plot surveys for plots already selected in the ALE and North Slope areas will be targeted for survey during the 1994 fiscal year. This strategy will provide an opportunity to meet Section 110 compliance needs (see Section 6.0) and will add additional survey data to the existing database for ALE and the North Slope. In addition, findings from 1992 and 1993 test excavations at site $45 \mathrm{BN} 163$ will be reported to make them available to other researchers and the public.

\subsubsection{Multiple Property Documentation Form}

This activity will entail the completion of the Multiple Property Documentation (MPD) Form for the Historic and Architectural Resource District of the Hanford Site. The historic context for the Manhattan Project Period will be edited and reorganized. A selected number of associated property types and subtypes have been identified in this context. This list will be expanded and re-formatted to comply with National Park Service submission criteria for the MPD Form (NPS 10-900-b). Reformatting of each property type and subtype includes expansion and completion of physical descriptions and functions, statements of significance and registration requirements for National Register listing. Additionally, a field inventory of extant buildings of association property types and subtypes needs to 
be accomplished for determinations of National Register eligibility and future completion of individual nominations to the Register under this MPD. Additional historic contexts have been identified. During FY 1994, a literature review of the proposed historic context will begin.

\subsection{Data Management}

During the course of FY 1993, the HCRL has been working toward the design of a database that would implement geographic information system (GIS) functions, as well as provide computerized ways of handling the data coming into the HCRL from various projects and on-going work. In July 1993, the Office of Hanford Environment contracted with the PNL Computer Science Department to do a needs assessment specifically addressing the issue of sharing the cultural resources data. Since most of HCRL's data is not computerized, the design, development, and implementation of a database and presentation method like GIS was identified as a priority. In October 1993, Advanced Sciences, Inc. was contracted by DOE to prepare a data overlay of cultural resources information for the statewide GIS, the Hanford Environmental Information System (HEIS).

In December 1993, the HCRL completed a database application and GIS design that will steer the implementation of the computerized system in 1994. The work now being considered by the HCRL will develop a GIS base map backed by a dynamic, full-featured database. A wide variety of GIS data overlays then can be created on demand to fulfill the diverse data presentation and analysis needs of the $\mathrm{HCRL}$, as well as those of other potential users like project managers, land use planners, other researchers, and potentially the public.

The challenge is to successfully implement a dynamic cultural resources data management system with GIS components that maintains ease of use and quick response while supporting specific security and integrity problems relevant to cultural resources data management. It is essential that the effort be modular so that critical functions come into use as early as possible while development of other phases continues. The design development must be efficient and responsive to demands of funding and the needs of the clients.

\subsubsection{Development in Phases}

The following demonstrates the ability to stagger development of the database into phases so that functionality is available on each completed phase. Software modularity allows us to ensure we have the quality and functionality we design throughout the product by getting a sense of what future phases will be like before they are completed, thereby allowing ease of design change.

Phase 1 Section 106 review and GIS, project and contract tracking. Some prehistoric and historic population distribution analysis.

Phase 2 Site records management, Site Form production, and some site report functions. 
Phase 3 Collection management, curation management, all analyses, report generation.

Phase 4 Develop use of handheld computers as a field data recording tool, and use of a global positioning system (GPS), especially integrated into the handheld computers. This can be done anytime after Phase 1. It should be done early to get as much benefit from its use as possible.

\subsubsection{Options for Design and Implementation}

Various options exist for implementing these GIS and database needs that should be determined by priorities and constraints imposed by HCRL or its clients. Care should also be taken as far as planning for future directions in use of the system, such as potentially making it available as a marketable product. Legal issues of copyrights on software ownership need to be assessed.

Given the explosive interest in GIS and data management systems to assist all sizes of public land managers in cultural resource management, this product should be considered an intellectual property of Battelle, with a system that could be useful at a variety of government sites. Thus some generality in data item codes and functions may be included to maintain this broader use of the archaeological GIS and database application. By focusing on a database/GIS system sizing that is smaller than many of the current offerings, but that keeps a full set of cultural resource management and GIS features, the product would be very useful to many of the public land managers whose expertise may not be in archaeology.

Decisions concerning hardware platforms and software development platforms must be made that guarantee data integrity and security, but still allow access to software for the purpose of appropriate data sharing, enhancement, and maintenance. Software should be considered first since it tends to drive hardware choices.

\subsubsection{Summary}

In summary, the HCRL should fulfill most of its data management objectives in FY 1994. These will focus on expediting Section 106 review processes through the implementation of a GIS mapping of project and site data, and also increasing efficiency in data collection and the application of this data to the various regulatory tasks the HCRL performs for its clients.

\subsection{Curation}

The main curation objective in FY 1994 is to complete the inventory of artifacts housed at HCRL. The inventory must be complete by 1995 as mandated by NAGPRA. The HCRL will also attempt to retrieve collections taken from the Hanford Site that are currently housed at the University of Idaho. 


\subsection{Archaeological Protection}

Archaeological site protection plans drafted in 1989 will be updated to reflect the multi-faceted education, surveillance, protection, and mitigation programs currently being developed.

\subsection{Education}

The key element in this task for 1994 is completion of one or more of the traveling displays designed to educate the Hanford work force about cultural resources management. Presentations to schools and lay and professional organizations will continue, along with journal publication of research findings.

Another education objective for HCRL in FY 1994 is developing and implementing an in-house training program on the identification, evaluation and protection process of historic period buildings, structures and sites.

\subsection{Research}

Research efforts in 1994 will address cultural interfaces between prehistoric populations, historic ethnographic populations, and Euro-American settlement patterns and the interrelationships that developed between each of these populations and the environment. 


\subsection{References}

Chatters, J. C. 1989. Hanford Cultural Resources Management Plan. PNL-6942, Pacific Northwest Laboratory, Richland, Washington.

Chatters, J. C., N. A. Cadoret, and P. E. Minthorn. 1990. Hanford Cultural Resources Laboratory Annual Report for Fiscal Year 1989. PNL-7362, Pacific Northwest Laboratory, Richland, Washington.

Chatters, J. C., H. A. Gard, and P. E. Minthorn. 1991. Hanford Cultural Resources Laboratory Annual Report for Fiscal Year 1990. PNL-7853, Pacific Northwest Laboratory, Richland, Washington.

Chatters, J. C., H. A. Gard, and P. E. Minthorn. 1992. Hanford Cultural Resources Laboratory Annual Report for Fiscal Year 1991. PNL-8101, Pacific Northwest Laboratory, Richland, Washington.

Chatters, J. C., H. A. Gard, M. K. Wright, M. E. Crist, J. G. Longenecker, T. K. O'Neil, and M. V. Dawson. 1993. Hanford Cultural Resources Laboratory Annual Report for Fiscal Year 1992. PNL-8676, Pacific Northweșt Laboratory, Richland, Washington.

Rice, D. G. 1968. Archeological Reconnaissance: Hanford Atomic Works. National Park Service, U.S. Atomic Energy Commission. Washington State University, Pullman, Washington. 


\subsection{Bibliography}

Gibson, Eric C., Principal Investigator. 1984. A Report of Archaeological Investigations at the Two Rivers Site (45BN14), at the Confluence of the Snake and Columbia Rivers. Professional Analysts for Walla Walla District, U.S. Army Corps of Engineers. Eugene, Oregon. 
Appendix A

Section 106 Reviews Conducted in FY 1993 


\section{Appendix A}

\section{Section 106 Reviews Conducted in FY 1993}

This appendix presents a table listing the NHPA Section 106 cultural resource reviews that were requested by Hanford Site contractors and the DOE-RL during FY 1993.

A.1 
Table A.1. Cultural Resource Reviews Requested of the HCRL in FY 1993.

\begin{tabular}{|c|c|c|c|c|c|c|c|c|}
\hline Case \# & Project Name & Class & $\begin{array}{c}\text { Date } \\
\text { Received }\end{array}$ & Survey & Monitoring & $\begin{array}{c}\text { Date } \\
\text { Completed }\end{array}$ & $\begin{array}{c}\text { Requesting } \\
\text { Organization }\end{array}$ & $\begin{array}{c}\text { Cultural } \\
\text { Resources? }\end{array}$ \\
\hline $92-0100-026$ & 100-NR-1 OP UNIT Borings & III & $10 / 9 / 92$ & N/A & N/A & $10 / 9 / 92$ & WHC & no known \\
\hline $92-0100-028$ & 100-BC-1 Trenching & III & $10 / 16 / 92$ & N/A & N/A & $11 / 3 / 92$ & WHC & no known \\
\hline $92-0100-029$ & 100-FR-1 Boreholes & III & $11 / 11 / 92$ & N/A & N/A & $11 / 12 / 92$ & WHC & no known \\
\hline $92-0100-033$ & $\begin{array}{l}\text { Demolition of } \\
\text { Building } 1702-\mathrm{KW}\end{array}$ & VI & $11 / 16 / 92$ & N/A & N/A & $12 / 16 / 92$ & WHC & no known \\
\hline $92-0100-034$ & \begin{tabular}{|l} 
Demolition of \\
Building $1702-\mathrm{KE}$
\end{tabular} & VI & $11 / 16 / 92$ & $\mathrm{~N} / \mathrm{A}$ & N/A & $12 / 16 / 92$ & WHC & no known \\
\hline $92-0100-035$ & $\begin{array}{l}\text { Columbia River Sediment } \\
\text { Sampling }\end{array}$ & III & $10 / 8 / 92$ & $\mathrm{~N} / \mathrm{A}$ & N/A & $12 / 16 / 92$ & WHC & no known \\
\hline $92-0200-011$ & $\begin{array}{l}\text { 200E Installation Distribution } \\
\text { Cables }\end{array}$ & III & $10 / 20 / 92$ & N/A & N/A & $10 / 20 / 92$ & WAHCO & no known \\
\hline $92-0200-012$ & 232Z Building Demolition & VI & $10 / 23 / 92$ & $\mathrm{~N} / \mathrm{A}$ & N/A & $10 / 26 / 92$ & ASI & no known \\
\hline $92-0200-013$ & $\begin{array}{l}200 \mathrm{~W}, 3 \text { Wells for Soil } \\
\text { Characterization }\end{array}$ & III & $10 / 23 / 92$ & $\mathrm{~N} / \mathrm{A}$ & N/A & $10 / 26 / 92$ & $\overline{\mathrm{WHC}}$ & no known \\
\hline $92-0200-014$ & 200W Phase II & III & $11 / 12 / 92$ & $\mathrm{~N} / \mathrm{A}$ & $\mathrm{N} / \mathrm{A}$ & $11 / 11 / 92$ & WAHCO & no known \\
\hline $92-0200-015$ & 200E Phase III & III & $11 / 12 / 92$ & $\mathrm{~N} / \mathrm{A}$ & N/A & $11 / 11 / 92$ & WAHCO & no known \\
\hline $92-0200-016$ & $\begin{array}{l}\text { Hanford IVDTS, Job } \\
\text { No. 200W-9-III }\end{array}$ & III/IV & $12 / 7 / 92$ & 1990 & needed & & WAHCO & $\begin{array}{l}\text { White } \\
\text { Bluffs Road }\end{array}$ \\
\hline
\end{tabular}


Table A.1. (Contd)

\begin{tabular}{|c|c|c|c|c|c|c|c|c|}
\hline Case \# & Project Name & Class & $\begin{array}{c}\text { Date } \\
\text { Received }\end{array}$ & Survey & Monitoring & $\begin{array}{c}\text { Date } \\
\text { Completed }\end{array}$ & $\begin{array}{l}\text { Requesting } \\
\text { Organization }\end{array}$ & $\begin{array}{c}\text { Cultural } \\
\text { Resources? }\end{array}$ \\
\hline $92-0300-040$ & $\begin{array}{l}\text { 384 Building Process Water } \\
\text { Flow Reduction }\end{array}$ & III & $10 / 27 / 92$ & N/A & $\mathrm{N} / \mathrm{A}$ & $10 / 30 / 92$ & WHC & no known \\
\hline $92-0300-041$ & 300 Area IVDTS, Plan I of VI & III & $11 / 2 / 92$ & $\mathrm{~N} / \mathrm{A}$ & $\mathrm{N} / \mathrm{A}$ & $11 / 12 / 92$ & WHC & no known \\
\hline $92-0300-042$ & 314 Building Modification & VI & $11 / 3 / 92$ & & & & & \\
\hline $92-0300-043$ & $\begin{array}{l}\text { 305B Building HLAN } \\
\text { Installation }\end{array}$ & III & $11 / 2 / 92$ & N/A & $\mathrm{N} / \mathrm{A}$ & $11 / 5 / 92$ & WHC & no known \\
\hline $92-0300-044$ & $\begin{array}{l}\text { Office Addition, } 324 \text { Building, } \\
\text { Project D-431 }\end{array}$ & VI & $10 / 28 / 92$ & N/A & $\mathrm{N} / \mathrm{A}$ & $11 / 30 / 92$ & PNL & no known \\
\hline $92-0300-045$ & $\begin{array}{l}333 \text { Building Pyrophoric Fines } \\
\text { Removal }\end{array}$ & VI & $11 / 16 / 92$ & N/A & N/A & $11 / 16 / 92$ & WHC & no known \\
\hline $92-0300-046$ & $\begin{array}{l}\text { 92G-EWL-109, } 384 \text { Building } \\
\text { Control Room Expansion }\end{array}$ & VI & $11 / 4 / 92$ & N/A & $\mathrm{N} / \mathrm{A}$ & $11 / 24 / 92$ & WHC & no known \\
\hline $92-0300-047$ & $\begin{array}{l}\text { 92G-EWL-071, Steam Plant } \\
\text { Safety Improvements }\end{array}$ & VI & $11 / 4 / 92$ & N/A & $\mathrm{N} / \mathrm{A}$ & $11 / 24 / 92$ & WHC & no known \\
\hline $92-0300-048$ & $\begin{array}{l}\text { 92-EWL-118, Standby } \\
\text { Generator Building 3621-B/C }\end{array}$ & VI & $11 / 6 / 92$ & N/A & N/A & $11 / 24 / 92$ & WHC & no known \\
\hline $92-0300-049$ & $\begin{array}{l}\text { Excavate and Repair all Leaks } \\
\text { at } 366 \mathrm{Bldg}\end{array}$ & VI & $12 / 14 / 92$ & N/A & $\mathrm{N} / \mathrm{A}$ & $12 / 15 / 92$ & WHC & no known \\
\hline $92-0300-050$ & $\begin{array}{l}\text { Repair and Replace Water } \\
\text { Valves - } 331 \text { Bldg }\end{array}$ & VI & $12 / 14 / 92$ & N/A & N/A & $12 / 15 / 92$ & WHC & no known \\
\hline $92-0600-040$ & Building 616 Paving & III & $10 / 22 / 92$ & N/A & $\mathrm{N} / \mathrm{A}$ & $10 / 26 / 92$ & WHC & no known \\
\hline $92-0600-041$ & $\begin{array}{l}\text { Modifications to Fire } \\
\text { Pumphouse 6652PH }\end{array}$ & II & $10 / 27 / 92$ & $10 / 30 / 92$ & needed & FY 1994 & $\overline{P N L}$ & none found \\
\hline $92-0600-042$ & $\begin{array}{l}\text { Historical Clnc for Selected } \\
\text { Structures-Hanford Site }\end{array}$ & VI & & \multicolumn{3}{|c|}{ Complete in FY 1994} & WHC & \\
\hline
\end{tabular}


Table A.1. (Contd)

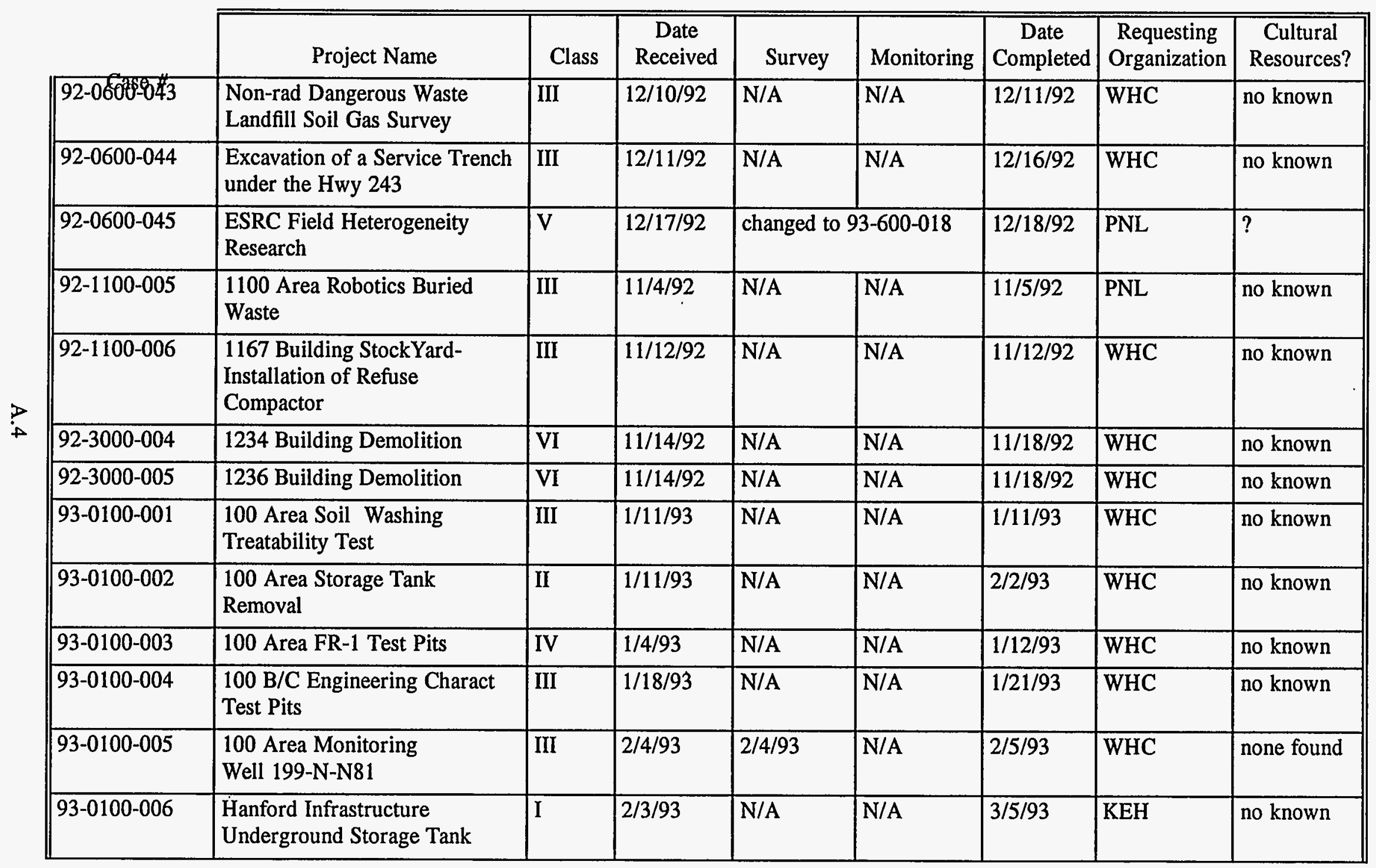


Table A.1. (Contd)

\begin{tabular}{|c|c|c|c|c|c|c|c|c|}
\hline Case \# & Project Name & Class & $\begin{array}{c}\text { Date } \\
\text { Received }\end{array}$ & Survey & Monitoring & \begin{tabular}{|c|} 
Date \\
Completed
\end{tabular} & $\begin{array}{c}\text { Requesting } \\
\text { Organization }\end{array}$ & $\begin{array}{c}\text { Cultural } \\
\text { Resources? }\end{array}$ \\
\hline $93-0100-007$ & $\begin{array}{l}\text { Siting of Hazardous Waste } \\
\text { Storage Locker in } 100,200 \text {, } \\
300, \& 3000 \text { Areas }\end{array}$ & III/IV & $2 / 25 / 93$ & $\mathrm{~N} / \mathrm{A}$ & $\mathrm{N} / \mathrm{A}$ & $4 / 6 / 93$ & $\overline{\mathrm{KEH}}$ & $\begin{array}{l}\text { Disturbed } \\
\text { area }\end{array}$ \\
\hline $93-0100-008$ & $\begin{array}{l}\text { W-252, Phase II - Liquid } \\
\text { Effluent Treatment \& Disposal }\end{array}$ & III & $2 / 25 / 93$ & $\mathrm{~N} / \mathrm{A}$ & N/A & $4 / 12 / 93$ & WHC & no known \\
\hline $93-0100-011$ & $\begin{array}{l}\text { 185/190-B Building } \\
\text { Demolitions }\end{array}$ & VI & $3 / 5 / 93$ & $5 / 6 / 93$ & N/A & $8 / 4 / 93$ & WHC & $\begin{array}{l}\text { constructed } \\
1944\end{array}$ \\
\hline $93-0100-012$ & $\begin{array}{l}2 \text { Power Poles at } 100 \mathrm{~N} \text { Addit. } \\
2 \text { poles: }\end{array}$ & III & $\begin{array}{l}3 / 25 / 93 \\
7 / 14 / 93\end{array}$ & $\begin{array}{l}\text { N/A } \\
\text { N/A }\end{array}$ & $\begin{array}{l}\text { N/A } \\
\text { N/A }\end{array}$ & $\begin{array}{l}3 / 30 / 93 \\
7 / 14 / 93\end{array}$ & WHC & $\begin{array}{l}\text { no known } \\
\text { no known }\end{array}$ \\
\hline $93-0100-015$ & $\begin{array}{l}\text { Replace \& Expand Existing } \\
\text { Septic Drain Field }\end{array}$ & III & $4 / 7 / 93$ & N/A & N/A & $4 / 7 / 93$ & $\overline{\text { WHC }}$ & no known \\
\hline $93-0100-016$ & $\begin{array}{l}\text { Repair Fire Hydrants FH-15 } \\
(100 \mathrm{~N}), 142 \text { (Trailer MO-244), } \\
221 \text { B/F-2B, \& FH-9 (100H) }\end{array}$ & I & $4 / 13 / 93$ & N/A & $\overline{N / A}$ & $4 / 28 / 93$ & WHC & no known \\
\hline $93-0100-017$ & $\begin{array}{l}\text { Three Monitoring Wells at the } \\
\text { Grout Treatment Facility }\end{array}$ & III & $4 / 15 / 93$ & $2 / 4 / 93$ & N/A & $4 / 16 / 93$ & WHC & none found \\
\hline
\end{tabular}


Table A.1. (Contd)

\begin{tabular}{|c|c|c|c|c|c|c|c|c|}
\hline Case \# & Project Name & Class & $\begin{array}{c}\text { Date } \\
\text { Received }\end{array}$ & Survey & Monitoring & $\begin{array}{c}\text { Date } \\
\text { Completed }\end{array}$ & $\begin{array}{c}\text { Requesting } \\
\text { Organization }\end{array}$ & $\begin{array}{c}\text { Cultural } \\
\text { Resources? }\end{array}$ \\
\hline $93-0100-018$ & $\begin{array}{l}\text { HLAN and Telephone Cable } \\
\text { Installation between MO-301 } \\
\text { and the perimeter fence }-100 \mathrm{~N}\end{array}$ & $I$ & $4 / 20 / 93$ & N/A & N/A & $4 / 22 / 93$ & WHC & no known \\
\hline 93-0100-019 & $\begin{array}{l}\text { Correction Action Backfill } \\
118-\mathrm{B}-4 \text { \& } 116-\mathrm{K}-2\end{array}$ & I & $4 / 19 / 93$ & N/A & $\mathrm{N} / \mathrm{A}$ & $4 / 23 / 93$ & WHC & no known \\
\hline $93-0100-021$ & Building 1704-D Demolition & VI & $4 / 15 / 93$ & $8 / 30 / 93$ & N/A & FY 1994 & WHC & $\begin{array}{l}\text { constructed } \\
1952\end{array}$ \\
\hline $93-0100-022$ & Building 1701-FA Demolition & VI & $4 / 15 / 93$ & $8 / 30 / 93$ & $\mathrm{~N} / \mathrm{A}$ & FY 1994 & $\overline{W H C}$ & $\begin{array}{l}\text { constructed } \\
1959\end{array}$ \\
\hline $93-0100-023$ & Building 1702-DR Demolition & VI & $4 / 15 / 93$ & $8 / 30 / 93$ & N/A & $12 / 1 / 93$ & WHC & $\begin{array}{l}\text { constructed } \\
1950\end{array}$ \\
\hline $93-0100-025$ & $\begin{array}{l}\text { 1721K Trailer Transformer } \\
\text { Upgrade }\end{array}$ & III & $4 / 22 / 93$ & N/A & N/A & $5 / 6 / 93$ & $\overline{\mathrm{WHC}}$ & no known \\
\hline $93-0100-026$ & $\begin{array}{l}100 \text { N Reactor Facilities } \\
\text { Stabilization }\end{array}$ & VI & $4 / 28 / 93$ & \multicolumn{3}{|c|}{ Complete in FY 1994} & WHC & \\
\hline $93-0100-027$ & $\begin{array}{l}100 \mathrm{~K} \text { Area Facilities } \\
\text { Operations }\end{array}$ & VI & $4 / 28 / 93$ & \multicolumn{3}{|c|}{ Complete in FY 1994} & WHC & \\
\hline $93-0100-028$ & $100 \mathrm{~K}$ Facilities Stabilization & VI & $4 / 28 / 93$ & \multicolumn{3}{|c|}{ Complete in FY 1994} & WHC & \\
\hline $93-0100-029$ & $\begin{array}{l}\text { Columbia River Emergency } \\
\text { Warning Siren System }\end{array}$ & III/V & $5 / 4 / 93$ & $5 / 10 / 93$ & N/A & $5 / 19 / 93$ & WHC & none found \\
\hline $93-0100-030$ & $\begin{array}{l}\text { Repair Existing Lawn } \\
\text { Sprinklers at } 100 \mathrm{~N}\end{array}$ & $\mathrm{I}$ & $5 / 12 / 93$ & N/A & $N / A$ & $5 / 17 / 93$ & WHC & no known \\
\hline
\end{tabular}


Table A.1. (Contd)

\begin{tabular}{|c|c|c|c|c|c|c|c|c|}
\hline Case \# & Project Name & Class & $\begin{array}{c}\text { Date } \\
\text { Received }\end{array}$ & Survey & Monitoring & $\begin{array}{c}\text { Date } \\
\text { Completed }\end{array}$ & \begin{tabular}{|c|} 
Requesting \\
Organization
\end{tabular} & $\begin{array}{c}\text { Cultural } \\
\text { Resources? }\end{array}$ \\
\hline $93-0100-031$ & $\begin{array}{l}\text { 100-BC-2 Remedial } \\
\text { Investigation }\end{array}$ & III & $5 / 13 / 93$ & $\mathrm{~N} / \mathrm{A}$ & $\mathrm{N} / \mathrm{A}$ & $5 / 21 / 93$ & WHC & no known \\
\hline $93-0100-032$ & $\begin{array}{l}\text { Export Water Tie-In, } \\
\text { ECN } 163684\end{array}$ & III & $5 / 13 / 93$ & $\mathrm{~N} / \mathrm{A}$ & N/A & $5 / 17 / 93$ & WHC & no known \\
\hline $93-0100-033$ & $\begin{array}{l}\text { Relocate } 1118 \mathrm{~N} \text { from } 100 \mathrm{~N} \text { to } \\
100 \mathrm{~K}\end{array}$ & III & $6 / 2 / 93$ & N/A & N/A & $6 / 14 / 93$ & WHC & no known \\
\hline $93-0100-035$ & $\begin{array}{l}\text { Installation of Continuous Air } \\
\text { Monitors }\end{array}$ & III & $6 / 8 / 93$ & $\mathrm{~N} / \mathrm{A}$ & N/A & $6 / 14 / 93$ & WHC & no known \\
\hline $93-0100-036$ & $\begin{array}{l}165 \mathrm{KW} \text { Underground Storage } \\
\text { Tank Removal }\end{array}$ & $I$ & $6 / 9 / 93$ & N/A & N/A & $6 / 16 / 93$ & WHC & no known \\
\hline $93-0100-039$ & $\begin{array}{l}\text { Move } 107 \mathrm{~N} \text { Air Compressor to } \\
105 \mathrm{~N} \text { and Install }\end{array}$ & $\overline{V I}$ & $6 / 14 / 93$ & $\mathrm{~N} / \mathrm{A}$ & N/A & $6 / 18 / 93$ & WHC & $\begin{array}{l}\text { constructed } \\
1983(107), \\
1963(105)\end{array}$ \\
\hline $93-0100-040$ & $\begin{array}{l}\text { 165KW Electrical Supply } \\
\text { System Modification }\end{array}$ & $\overline{V I}$ & $6 / 18 / 93$ & $\mathrm{~N} / \mathrm{A}$ & N/A & $6 / 21 / 93$ & WHC & $\begin{array}{l}\text { constructed } \\
1955\end{array}$ \\
\hline 93-0100-041 & Demolition of Building complex & VI & $6 / 21 / 93$ & $9 / 2 / 93$ & N/A & FY 1994 & WHC & $\begin{array}{l}185 / 189 \\
\text { pot. eligible }\end{array}$ \\
\hline $93-0100-042$ & Demolition of Building $1101-\mathrm{N}$ & VI & $6 / 21 / 93$ & $8 / 30 / 93$ & N/A & FY 1994 & WHC & pot. eligible \\
\hline $93-0100-043$ & Duplicated project number & $\mathrm{XX}$ & $\mathrm{XX}$ & $\overline{X X}$ & $\mathrm{XX}$ & $\mathrm{XX}$ & $\mathrm{XX}$ & $\mathrm{XX}$ \\
\hline
\end{tabular}


Table A.1. (Contd)

\begin{tabular}{|c|c|c|c|c|c|c|c|c|}
\hline Case \# & Project Name & Class & $\begin{array}{c}\text { Date } \\
\text { Received }\end{array}$ & Survey & Monitoring & $\begin{array}{c}\text { Date } \\
\text { Completed }\end{array}$ & \begin{tabular}{|c|} 
Requesting \\
Organization
\end{tabular} & $\begin{array}{c}\text { Cultural } \\
\text { Resources? }\end{array}$ \\
\hline $93-0100-044$ & Demolition of Building $1100-\mathrm{N}$ & VI & $6 / 21 / 93$ & $8 / 30 / 93$ & N/A & FY 1994 & WHC & pot. eligible \\
\hline $93-0100-045$ & 100-DR-2 Operable Unit RI/FS & III & $6 / 29 / 93$ & N/A & N/A & $7 / 6 / 93$ & WHC & no known \\
\hline $93-0100-046$ & $\begin{array}{l}\text { Cone Penetrometer Work-- } \\
100 \text { Area Excavation } \\
\text { Treatability Study }\end{array}$ & III & $6 / 28 / 93$ & N/A & N/A & $7 / 7 / 93$ & WHC & no known \\
\hline $93-0100-047$ & $\begin{array}{l}\text { 100N Area Facility Air Effluent } \\
\text { Sampling Equipment Upgrade }\end{array}$ & VI & $7 / 1 / 93$ & $\mathrm{~N} / \mathrm{A}$ & N/A & $7 / 7 / 93$ & WHC & \begin{tabular}{|l|}
$105 \mathrm{~N}--$ \\
1963, \\
$107 \mathrm{~N}-1983$
\end{tabular} \\
\hline $93-0100-048$ & $\begin{array}{l}\text { 105KE/KW Basins Monitoring } \\
\text { Equipment Replacement }\end{array}$ & VI & $7 / 1 / 93$ & $\mathrm{~N} / \mathrm{A}$ & N/A & $7 / 7 / 93$ & WHC & $\begin{array}{l}\text { constructed } \\
1955\end{array}$ \\
\hline 93-0100-049 & $\begin{array}{l}\text { Reconfigure Existing } \\
\text { Compressed Air System (105N } \\
\& 163 N)\end{array}$ & III/VI & $7 / 1 / 93$ & N/A & N/A & $7 / 7 / 93$ & WHC & $\begin{array}{l}\text { constructed } \\
\text { in '60s \& } \\
\text { ' } 80 \text { s }\end{array}$ \\
\hline $93-0100-050$ & $1127 \mathrm{~N}$ Trailer Relocation & III & $7 / 1 / 93$ & $\mathrm{~N} / \mathrm{A}$ & $\mathrm{N} / \mathrm{A}$ & $7 / 7 / 93$ & WHC & no known \\
\hline $93-0100-051$ & $\begin{array}{l}\text { 1119N/MO403 Trailer } \\
\text { Modification }\end{array}$ & $\overline{V I}$ & $7 / 1 / 93$ & N/A & N/A & $7 / 7 / 93$ & WHC & $\begin{array}{l}\text { constructed } \\
1977\end{array}$ \\
\hline $93-0100-052$ & $1118 \mathrm{~N}$ Trailer Relocation & III/VI & $7 / 1 / 93$ & N/A & N/A & $7 / 7 / 93$ & WHC & no known \\
\hline $93-0100-053$ & $\begin{array}{l}\text { 100-DR-2 Sodium Dichromate } \\
\text { Unloading Station Soil Investig. }\end{array}$ & III & $7 / 12 / 93$ & $\mathrm{~N} / \mathrm{A}$ & N/A & $7 / 13 / 93$ & WHC & no known \\
\hline $93-0100-054$ & $\begin{array}{l}\text { W-342 Treatability Lab Load/ } \\
\text { Unload Station }\end{array}$ & III & $7 / 12 / 93$ & $\mathrm{~N} / \mathrm{A}$ & N/A & $7 / 20 / 93$ & WHC & no known \\
\hline $93-0100-055$ & $\begin{array}{l}\text { Shutdown 183D Water Filter } \\
\text { Plant--Project E-019 }\end{array}$ & III & $7 / 30 / 93$ & $\mathrm{~N} / \mathrm{A}$ & N/A & $8 / 2 / 93$ & WHC & no known \\
\hline $93-0100-056$ & $\begin{array}{l}\text { Conex Storage Unit Lights } \\
\text { Installation }\end{array}$ & III & $8 / 4 / 93$ & $\mathrm{~N} / \mathrm{A}$ & N/A & $8 / 5 / 93$ & WHC & no known \\
\hline
\end{tabular}




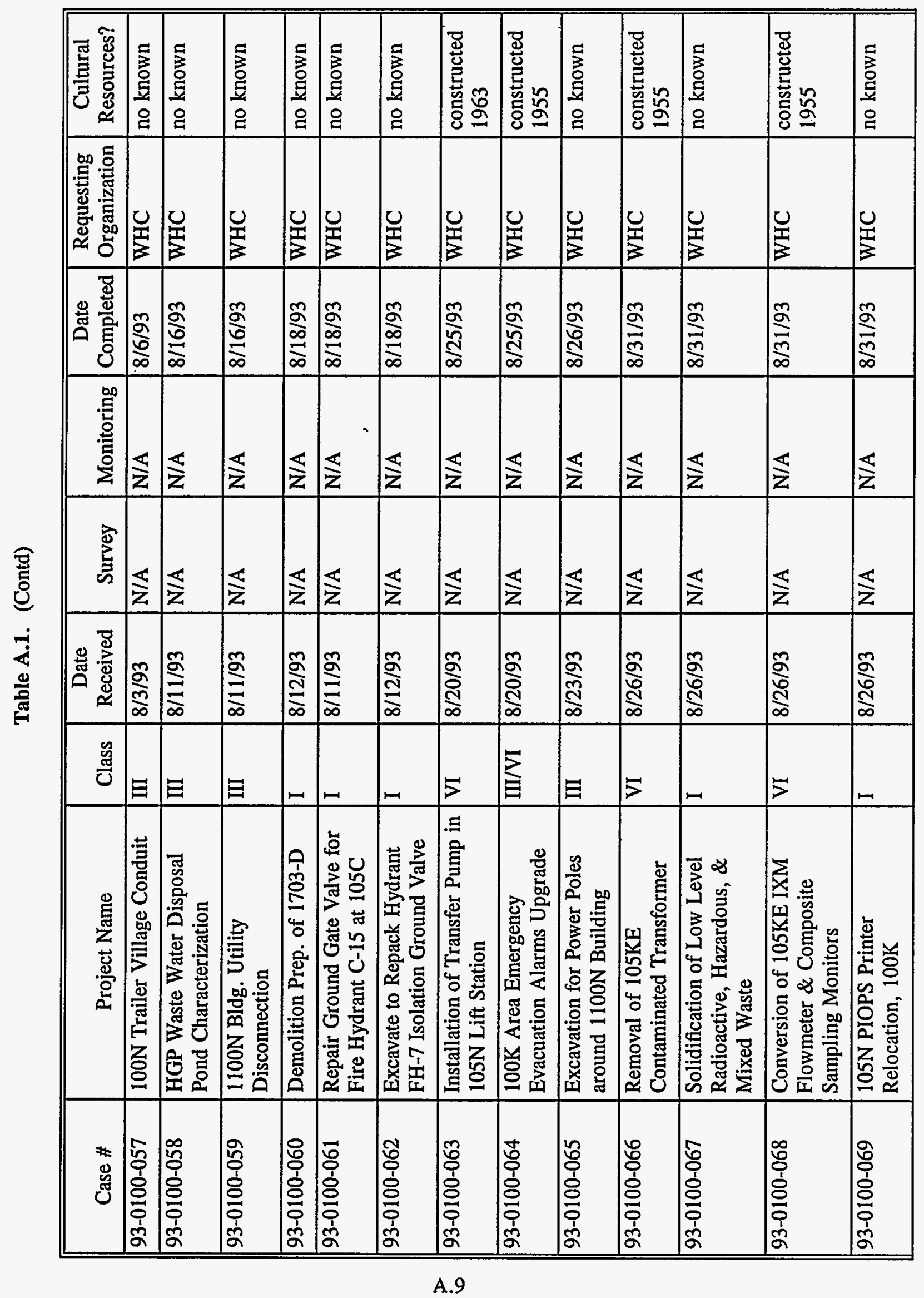


Table A.1. (Contd)

\begin{tabular}{|c|c|c|c|c|c|c|c|c|}
\hline Case \# & Project Name & Class & $\begin{array}{c}\text { Date } \\
\text { Received }\end{array}$ & Survey & Monitoring & \begin{tabular}{|c|} 
Date \\
Completed
\end{tabular} & $\begin{array}{c}\text { Requesting } \\
\text { Organization }\end{array}$ & $\begin{array}{c}\text { Cultural } \\
\text { Resources? }\end{array}$ \\
\hline $93-0100-070$ & $\begin{array}{l}\text { Decontamination of the } \\
107 \mathrm{KE}, \mathrm{KW}, \& \mathrm{C} \text { Basins }\end{array}$ & III & $8 / 26 / 93$ & N/A & N/A & $9 / 8 / 93$ & $\overline{\text { WHC }}$ & no known \\
\hline $93-0100-071$ & $\begin{array}{l}1100 \mathrm{~N}, 1101 \mathrm{~N}, 1102 \mathrm{~N} \text { Bldg } \\
\text { Demos }\end{array}$ & VI & $8 / 27 / 93$ & \multicolumn{3}{|c|}{ Complete in FY 1994} & WHC & \\
\hline $93-0100-072$ & $\begin{array}{l}\text { Reservoir Expansion Joint } \\
\text { Repair }\end{array}$ & III & $8 / 31 / 93$ & N/A & $\mathrm{N} / \mathrm{A}$ & $9 / 1 / 93$ & WHC & no known \\
\hline $93-0100-074$ & $\begin{array}{l}\text { 1118N Trailer to K Area-- } \\
\text { Electrical Line to Septic Tank at } \\
100 \mathrm{~K}\end{array}$ & III & $9 / 9 / 93$ & N/A & N/A & $9 / 16 / 93$ & WHC & no known \\
\hline $93-0100-075$ & $\begin{array}{l}\text { Sanitary Sewer Capping at } \\
100 \mathrm{~N}\end{array}$ & $I$ & $9 / 9 / 93$ & $\mathrm{~N} / \mathrm{A}$ & N/A & $9 / 16 / 93$ & WHC & no known \\
\hline $93-0100-077$ & $\begin{array}{l}\text { Repair Hydrant } \mathrm{H}-9 \text { and } \\
\text { Ground Valve }\end{array}$ & $\mathbf{I}$ & $9 / 13 / 93$ & N/A & $\mathrm{N} / \mathrm{A}$ & $9 / 16 / 93$ & WHC & no known \\
\hline $93-0100-078$ & $\begin{array}{l}\text { Repair Broken Water Main in } \\
\text { 100B }\end{array}$ & I & $9 / 15 / 93$ & N/A & N/A & $9 / 16 / 93$ & WHC & no known \\
\hline 93-0100-079 & $1117 \mathrm{~N}$ Trailer Move to $\mathrm{K}$ Area & III & $9 / 30 / 93$ & N/A & N/A & $9 / 30 / 93$ & WHC & no known \\
\hline $93-0200-001$ & $\begin{array}{l}\text { ERDF-Environmental } \\
\text { Restoration Disposal Facility }\end{array}$ & V & $1 / 25 / 93$ & $\begin{array}{l}\text { Aug-Sept } \\
1993\end{array}$ & N/A & FY 1994 & WHC & $\begin{array}{l}5 \text { sites, } \\
9 \text { isolates }\end{array}$ \\
\hline $93-0200-002$ & $\begin{array}{l}\text { L-017-Steam System } \\
\text { Rehabilitation Phase II }\end{array}$ & III/VI & $2 / 11 / 93$ & N/A & $\mathrm{N} / \mathrm{A}$ & $4 / 12 / 93$ & WHC & $\begin{array}{l}\text { constructed } \\
1943\end{array}$ \\
\hline $93-0200-003$ & 200 Area, 201C Hot Semi & III & $2 / 30 / 93$ & $1987-1988$ & $N / A$ & $3 / 4 / 93$ & WHC & no known \\
\hline
\end{tabular}


Table A.1. (Contd)

\begin{tabular}{|c|c|c|c|c|c|c|c|c|}
\hline Case \# & Project Name & Class & $\begin{array}{c}\text { Date } \\
\text { Received }\end{array}$ & Survey & Monitoring & \begin{tabular}{|c|} 
Date \\
Completed
\end{tabular} & \begin{tabular}{|l|} 
Requesting \\
Organization
\end{tabular} & $\begin{array}{c}\text { Cultural } \\
\text { Resources? }\end{array}$ \\
\hline $93-0200-004$ & $\begin{array}{l}\text { 200-BP-1 Hanford Prototype } \\
\text { Barrier }\end{array}$ & III & $3 / 3 / 93$ & $4 / 2 / 93$ & N/A & $4 / 7 / 93$ & WHC & none found \\
\hline $93-0200-005$ & $\begin{array}{l}\text { Water Line Repair Excavation } \\
2704-\mathrm{S}\end{array}$ & I & $3 / 12 / 93$ & $3 / 12 / 93$ & N/A & $3 / 12 / 93$ & WHC & none found \\
\hline $93-0200-006$ & $\begin{array}{l}\text { Repair of Leaking Steam } \\
\text { Condensation Pipe Line at } \\
224 U\end{array}$ & I & $3 / 18 / 93$ & N/A & N/A & $3 / 18 / 93$ & WHC & no known \\
\hline 93-0200-007 & Trench 218-E, 200E Area & I & $3 / 18 / 93$ & $\mathrm{~N} / \mathrm{A}$ & N/A & $3 / 18 / 93$ & WHC & no known \\
\hline $93-0200-008$ & \begin{tabular}{|l|} 
TRU Waste Retrieval/ \\
Characterization Pilot Program
\end{tabular} & II & $3 / 8 / 93$ & N/A & N/A & $3 / 22 / 93$ & WHC & no known \\
\hline $93-0200-009$ & $\begin{array}{l}\text { Demolition of Bldgs. 2701-EC, } \\
\text { 2701-EF, 2701-WC, 2715-W }\end{array}$ & VI & $3 / 5 / 93$ & \multicolumn{3}{|c|}{ Complete in FY 1994} & WHC & \\
\hline $93-0200-010$ & Buffalo St. Water Line Repair & I & $3 / 22 / 93$ & N/A & N/A & $3 / 22 / 93$ & WHC & no known \\
\hline $93-0200-011$ & $\begin{array}{l}\text { Carbon Tetrachloride Vapor } \\
\text { Extraction ERA }\end{array}$ & III & $3 / 22 / 93$ & N/A & N/A & $3 / 25 / 93$ & WHC & no known \\
\hline 93-0200-012 & Borrow Pit at Purex & $\mathrm{V}$ & $3 / 22 / 93$ & 1988 & N/A & $3 / 23 / 93$ & WHC & none found \\
\hline $93-0200-013$ & \begin{tabular}{|l|} 
Installation of Services for \\
Double Wide Mobile Office
\end{tabular} & $\mathrm{I}$ & $3 / 25 / 93$ & N/A & N/A & $3 / 25 / 93$ & WHC & no known \\
\hline $93-0200-014$ & Repair of Leak in Water Line & I & $3 / 25 / 93$ & N/A & N/A & $3 / 26 / 93$ & WHC & no known \\
\hline $93-0200-015$ & \begin{tabular}{|l|} 
Interim Stabilization of \\
216-T-3, 216-T-6, \& 216-T-361
\end{tabular} & II & $3 / 26 / 93$ & N/A & $\mathrm{N} / \mathrm{A}$ & $3 / 26 / 93$ & WHC & no known \\
\hline $93-0200-016$ & $\begin{array}{l}\text { Interim Stabilization of } \\
\text { UN-216-W-24/30 }\end{array}$ & I & $3 / 26 / 93$ & N/A & N/A & $4 / 9 / 93$ & WHC & no known \\
\hline $93-0200-016 \mathrm{~A}$ & $\begin{array}{l}\text { 200E Steam Line Reroute } \\
\text { PUREX }\end{array}$ & 1 & $3 / 29 / 93$ & N/A & N/A & $4 / 1 / 93$ & WHC & no \\
\hline
\end{tabular}


Table A.1. (Contd)

\begin{tabular}{|c|c|c|c|c|c|c|c|c|}
\hline Case \# & Project Name & Class & $\begin{array}{c}\text { Date } \\
\text { Received }\end{array}$ & Survey & Monitoring & $\begin{array}{c}\text { Date } \\
\text { Completed }\end{array}$ & \begin{tabular}{|c|} 
Requesting \\
Organization
\end{tabular} & $\begin{array}{c}\text { Cultural } \\
\text { Resources? }\end{array}$ \\
\hline $93-0200-017$ & $124 / \mathrm{N} 9$ & I & $3 / 22 / 93$ & $\mathrm{~N} / \mathrm{A}$ & N/A & $3 / 30 / 93$ & WHC & no known \\
\hline $93-0200-018$ & Electrical Upgrades, MO-919 & I/III & $4 / 1 / 93$ & N/A & N/A & $4 / 6 / 93$ & WHC & no known \\
\hline 93-0200-019 & $\begin{array}{l}\text { Cass Cable Repair } \\
\text { 2E-91-00717/W }\end{array}$ & I & $4 / 5 / 93$ & $\mathrm{~N} / \mathrm{A}$ & N/A & $4 / 6 / 93$ & WHC & no known \\
\hline $93-0200-020$ & T Plant Facility Upgrades & VI & $4 / 1 / 93$ & $\mathrm{~N} / \mathrm{A}$ & N/A & $4 / 8 / 93$ & WHC & $\begin{array}{l}\text { constructed } \\
1944\end{array}$ \\
\hline $93-0200-021$ & $\begin{array}{l}\text { Replace Wiring to R-B220 at } \\
\text { 244-AR }\end{array}$ & I & $4 / 7 / 93$ & $\mathrm{~N} / \mathrm{A}$ & N/A & $4 / 7 / 93$ & WHC & no known \\
\hline $93-0200-022$ & $\begin{array}{l}\text { 12-Wide Modular Facility, } \\
\text { 200W, Project L-198 }\end{array}$ & III & $4 / 1 / 93$ & N/A & N/A & $4 / 13 / 93$ & WHC & no known \\
\hline $93-0200-023$ & $\begin{array}{l}\text { 12-Wide Modular Facility, } \\
\text { 200E Core Area, Project L-199 }\end{array}$ & III & $4 / 1 / 93$ & N/A & N/A & $4 / 13 / 93$ & WHC & no known \\
\hline $93-0200-024$ & $\begin{array}{l}\text { 12-Wide Modular Facility, } \\
\text { 200E, Project L-200 }\end{array}$ & III & $4 / 1 / 93$ & $\mathrm{~N} / \mathrm{A}$ & N/A & $4 / 13 / 93$ & WHC & no known \\
\hline $93-0200-025$ & $\begin{array}{l}\text { Leaking Steampipe Repair at } \\
\text { 2719-WA }\end{array}$ & I/VI & $4 / 12 / 93$ & N/A & N/A & $4 / 13 / 93$ & WHC & no known \\
\hline $93-0200-026$ & $\begin{array}{l}\text { W-188 Radiological Support } \\
\text { Facilities }\end{array}$ & III & $4 / 12 / 93$ & N/A & $\mathrm{N} / \mathrm{A}$ & $4 / 27 / 93$ & WHC & no known \\
\hline $93-0200-027$ & $\begin{array}{l}\text { Waste Sampling and } \\
\text { Characterization Facility-Water } \\
\text { Line }\end{array}$ & III/V & $4 / 15 / 93$ & $5 / 18 / 93$ & $\mathrm{~N} / \mathrm{A}$ & $6 / 8 / 93$ & WHC & none found \\
\hline $93-0200-028$ & $\begin{array}{l}\text { Corrective Maintenance } \\
\text { Package }\end{array}$ & I & $4 / 15 / 93$ & N/A & N/A & $4 / 15 / 93$ & WHC & no known \\
\hline 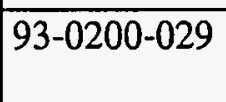 & $\begin{array}{l}\text { Hanford Waste Vitrification } \\
\text { Plan Water Pipe Installation }\end{array}$ & I & $4 / 20 / 93$ & $\mathrm{~N} / \mathrm{A}$ & $\mathrm{N} / \mathrm{A}$ & $4 / 21 / 93$ & WHC & no known \\
\hline
\end{tabular}


Table A.1. (Contd)

\begin{tabular}{|c|c|c|c|c|c|c|c|c|}
\hline Case \# & Project Name & Class & $\begin{array}{c}\text { Date } \\
\text { Received }\end{array}$ & Survey & Monitoring & \begin{tabular}{|c|} 
Date \\
Completed
\end{tabular} & \begin{tabular}{c|} 
Requesting \\
Organization
\end{tabular} & $\begin{array}{c}\text { Cultural } \\
\text { Resources? }\end{array}$ \\
\hline $93-0200-030$ & W-025 Landfill Excavation & III & $4 / 16 / 93$ & N/A & $\mathrm{N} / \mathrm{A}$ & $4 / 21 / 93$ & WHC & no known \\
\hline $93-0200-031$ & $\begin{array}{l}200 \text { W Low Level Burial } \\
\text { Ground }\end{array}$ & $\mathrm{I}$ & $4 / 21 / 93$ & $\mathrm{~N} / \mathrm{A}$ & $\mathrm{N} / \mathrm{A}$ & $4 / 21 / 93$ & WHC & no known \\
\hline $93-0200-032$ & Installation of a Facility Sign & $\mathrm{I}$ & $4 / 23 / 93$ & $\mathrm{~N} / \mathrm{A}$ & N/A & $4 / 23 / 93$ & WHC & no known \\
\hline $93-0200-033$ & $\begin{array}{l}\text { Interim Stabilization of } \\
\text { 241-WR Vault }\end{array}$ & III & $4 / 20 / 93$ & $\mathrm{~N} / \mathrm{A}$ & $\mathrm{N} / \mathrm{A}$ & $4 / 23 / 93$ & $\overline{\text { WHC }}$ & no known \\
\hline $93-0200-034$ & Repair 12 Sanitary Water Main & I & $4 / 20 / 93$ & N/A & $\mathrm{N} / \mathrm{A}$ & $4 / 27 / 93$ & WHC & no known \\
\hline 93-0200-035 & 2701 Z Demolition & VI & $4 / 28 / 93$ & $\mathrm{~N} / \mathrm{A}$ & $\mathrm{N} / \mathrm{A}$ & $8 / 10 / 93$ & WHC & $\begin{array}{l}\text { constructed } \\
1949\end{array}$ \\
\hline $93-0200-036$ & 200-UP-2 RFI/CMS & III & $5 / 7 / 93$ & $\mathrm{~N} / \mathrm{A}$ & $\mathrm{N} / \mathrm{A}$ & $5 / 11 / 93$ & WHC & no known \\
\hline 93-0200-037 & 291-Z-1 Stack & $\mathrm{I}$ & $5 / 10 / 93$ & $\mathrm{~N} / \mathrm{A}$ & $\mathrm{N} / \mathrm{A}$ & $5 / 13 / 93$ & WHC & $\begin{array}{l}\text { constructed } \\
1957\end{array}$ \\
\hline 93-0200-038 & $\begin{array}{l}\text { W-049H Treated Effluent } \\
\text { Disposal Facility Trailer }\end{array}$ & III & $5 / 11 / 93$ & N/A & N/A & $5 / 11 / 93$ & $\overline{\text { WHC }}$ & no known \\
\hline $93-0200-039$ & $\begin{array}{l}\text { Repair Sanitary Water Valve to } \\
\text { Lawn Sprinklers }\end{array}$ & $I$ & $5 / 12 / 93$ & N/A & $\mathrm{N} / \mathrm{A}$ & $5 / 12 / 93$ & WHC & no known \\
\hline 93-0200-040 & W-062 AP-104 Tank Upgrade & III & $5 / 12 / 93$ & N/A & N/A & $5 / 17 / 93$ & WHC & no known \\
\hline $93-0200-041$ & W-105 Pipe Project-200E & $I$ & $5 / 12 / 93$ & N/A & $\mathrm{N} / \mathrm{A}$ & $5 / 13 / 93$ & WHC & no known \\
\hline 93-0200-042 & $\begin{array}{l}\text { Repair Alarm Cables in } \\
\text { 241-C Tank Farm }\end{array}$ & I & $5 / 17 / 93$ & N/A & $\mathrm{N} / \mathrm{A}$ & $5 / 20 / 93$ & WHC & no known \\
\hline $93-0200-043$ & $\begin{array}{l}\text { Install Hold Down Device for } \\
\text { Generator Door }\end{array}$ & III & $5 / 18 / 93$ & N/A & N/A & $5 / 20 / 93$ & WHC & no known \\
\hline $93-0200-044$ & $\begin{array}{l}\text { 216-U-14 Ditch Liquid Effluent } \\
\text { Study }\end{array}$ & III & $5 / 19 / 93$ & N/A & $\mathrm{N} / \mathrm{A}$ & $5 / 21 / 93$ & WHC & no known \\
\hline
\end{tabular}


Table A.1. (Contd)

\begin{tabular}{|c|c|c|c|c|c|c|c|c|}
\hline Case \# & Project Name & Class & $\begin{array}{c}\text { Date } \\
\text { Received }\end{array}$ & Survey & Monitoring & $\begin{array}{c}\text { Date } \\
\text { Completed }\end{array}$ & $\begin{array}{l}\text { Requesting } \\
\text { Organization }\end{array}$ & $\begin{array}{c}\text { Cultural } \\
\text { Resources? }\end{array}$ \\
\hline $93-0200-045$ & $\begin{array}{l}\text { Water Service Caisson 243-G82 } \\
\text { to Raw Water Line }\end{array}$ & III & $5 / 24 / 93$ & N/A & N/A & $5 / 24 / 93$ & WHC & no known \\
\hline $93-0200-046$ & $\begin{array}{l}\text { W-087, Radioactive Liquid } \\
\text { Waste Line Replacement }\end{array}$ & $\mathrm{I} / \mathrm{III}$ & $5 / 26 / 93$ & N/A & N/A & $5 / 28 / 93$ & WHC & no known \\
\hline 93-0200-047 & $\begin{array}{l}\text { Carbon Tetrachloride Vapor } \\
\text { Extraction ERA }\end{array}$ & III & $5 / 21 / 93$ & N/A & N/A & $6 / 3 / 93$ & WHC & no known \\
\hline $93-0200-048$ & $\begin{array}{l}\text { Diesel Generator, Motor } \\
\text { Control Center, Concrete Pad } \\
\text { Installation at 291-S Bldg }\end{array}$ & III & $5 / 26 / 93$ & N/A & N/A & $6 / 3 / 93$ & WHC & no known \\
\hline 93-0200-049 & $\begin{array}{l}\text { Repair } 6 \text { Raw Water Leak by } \\
\text { 24R Valve }\end{array}$ & I & $6 / 2 / 93$ & N/A & N/A & $6 / 7 / 93$ & WHC & no known \\
\hline $93-0200-050$ & 241-S Transfer Lines & $I$ & $6 / 2 / 93$ & $\mathrm{~N} / \mathrm{A}$ & N/A & $6 / 3 / 93$ & WHC & no known \\
\hline $93-0200-051$ & $\begin{array}{l}\text { W-124, 222-S Waste Water } \\
\text { Retention Facility }\end{array}$ & III & $6 / 3 / 93$ & $\mathrm{~N} / \mathrm{A}$ & N/A & $6 / 9 / 93$ & WHC & no known \\
\hline $93-0200-052$ & Relocate 291-T Stack Monitor & $\mathrm{I}$ & $6 / 3 / 93$ & N/A & N/A & $6 / 9 / 93$ & WHC & no known \\
\hline $93-0200-053$ & $\begin{array}{l}\text { L-091, 200E Office Facility } \\
\text { Location Change: }\end{array}$ & III & $\begin{array}{l}6 / 4 / 93 \\
9 / 22 / 93\end{array}$ & N/A & N/A & $\begin{array}{l}6 / 9 / 93 \\
9 / 27 / 93\end{array}$ & WHC & $\begin{array}{l}\text { no known } \\
\text { no known }\end{array}$ \\
\hline $93-0200-054$ & Mobile Office Building & III & $6 / 7 / 93$ & $\mathrm{~N} / \mathrm{A}$ & N/A & $6 / 11 / 93$ & WHC & no known \\
\hline $93-0200-055$ & $\begin{array}{l}\text { Hazardous Waste Storage } \\
\text { Bldgs-200W } \\
\text { Additional Building: }\end{array}$ & III & $\begin{array}{l}6 / 7 / 93 \\
7 / 30 / 93\end{array}$ & $\begin{array}{l}\text { N/A } \\
\text { N/A }\end{array}$ & $\begin{array}{l}\text { N/A } \\
\text { N/A }\end{array}$ & $\begin{array}{l}6 / 11 / 93 \\
8 / 2 / 93\end{array}$ & WHC & no known \\
\hline $93-0200-056$ & $\begin{array}{l}\text { Relocate Temp. 242-S Bldg. } \\
\text { Air Compressor \& Air Dryer }\end{array}$ & $\mathrm{I}$ & $6 / 9 / 93$ & N/A & N/A & $6 / 15 / 93$ & WHC & no known \\
\hline $93-0200-057$ & $\begin{array}{l}\text { Clean Up Foundation Across } \\
\text { from } 272 \mathrm{E}\end{array}$ & I & $6 / 9 / 93$ & N/A & N/A & $6 / 15 / 93$ & WHC & no known \\
\hline
\end{tabular}


Table A.1. (Contd)

\begin{tabular}{|c|c|c|c|c|c|c|c|c|}
\hline Case \# & Project Name & Class & $\begin{array}{c}\text { Date } \\
\text { Received }\end{array}$ & Survey & Monitoring & \begin{tabular}{|c|} 
Date \\
Completed
\end{tabular} & $\begin{array}{l}\text { Requesting } \\
\text { Organization }\end{array}$ & $\begin{array}{l}\text { Cultural } \\
\text { Resources? }\end{array}$ \\
\hline 93-0200-058 & 201W Fence, Project L-210 & III & 6/9/93 & N/A & N/A & $6 / 15 / 93$ & WHC & no known \\
\hline $93-0200-059$ & \begin{tabular}{|l} 
Modify Air Line in \\
241-AP Compressor Room
\end{tabular} & $\mathrm{I}$ & $6 / 9 / 93$ & $\overline{\text { N/A }}$ & N/A & $6 / 14 / 93$ & WHC & no known \\
\hline $93-0200-060$ & Installation of Office/ER3873 & III & $6 / 10 / 93$ & $10 / 29 / 87$ & $\mathrm{~N} / \mathrm{A}$ & 6/17/93 & KEH & none found \\
\hline $93-0200-061$ & Air Purge Line at $200 \mathrm{~W}$ & $\mathrm{I}$ & $6 / 11 / 93$ & N/A & N/A & $6 / 16 / 93$ & $\overline{\text { WHC }}$ & no known \\
\hline $93-0200-062$ & 101-SY Mitigation & III & $6 / 14 / 93$ & $\mathrm{~N} / \mathrm{A}$ & N/A & 6/16/93 & WHC & no known \\
\hline $93-0200-063$ & $\begin{array}{l}\text { Install Temporary Air } \\
\text { Compressor }\end{array}$ & III & $6 / 14 / 93$ & $\mathrm{~N} / \mathrm{A}$ & $\mathrm{N} / \mathrm{A}$ & $6 / 17 / 93$ & WHC & no known \\
\hline $93-0200-064$ & Install TMACS in 241-SY & III & $6 / 17 / 93$ & N/A & N/A & $6 / 17 / 93$ & $\overline{\text { WHC }}$ & no known \\
\hline $93-0200-065$ & $\begin{array}{l}\text { Repair San Water Line to Tank } \\
\text { Farms }\end{array}$ & $I$ & $6 / 16 / 93$ & $\mathrm{~N} / \mathrm{A}$ & $\mathrm{N} / \mathrm{A}$ & $6 / 17 / 93$ & $\overline{\text { WHC }}$ & no known \\
\hline $93-0200-066$ & TRU Retrieval & III & $6 / 15 / 93$ & N/A & N/A & $6 / 18 / 93$ & $\overline{\text { WHC }}$ & no known \\
\hline 93-0200-067 & 271-U Heating & VI & 6/16/93 & N/A & N/A & $6 / 18 / 93$ & WHC & $\begin{array}{l}\text { constructed } \\
1952\end{array}$ \\
\hline 93-0200-068 & $\begin{array}{l}\text { KEH, ERP Dept. Asbestos } \\
\text { Abatement Equipment Storage } \\
\text { Facility }\end{array}$ & III & $6 / 16 / 93$ & 1990 & $\mathrm{~N} / \mathrm{A}$ & $6 / 18 / 93$ & WHC & none found \\
\hline 93-0200-069 & 480V Power Cable Replacement & 1 & $6 / 17 / 93$ & N/A & N/A & $6 / 18 / 93$ & WHC & no known \\
\hline 93-0200-070 & Asphalt Paving/Patching & $I$ & $6 / 17 / 93$ & N/A & N/A & $6 / 21 / 93$ & $\overline{\text { WHC }}$ & no known \\
\hline 93-0200-071 & 222SA Roof Fall Protection & $\mathrm{I}$ & $6 / 21 / 93$ & $\mathrm{~N} / \mathrm{A}$ & N/A & $6 / 24 / 93$ & WHC & no known \\
\hline $93-0200-072$ & $\begin{array}{l}\text { Replace Compressor in } \\
\text { 241-U Farm }\end{array}$ & $\mathrm{I}$ & $6 / 24 / 93$ & N/A & N/A & $6 / 24 / 93$ & $\overline{\text { WHC }}$ & no known \\
\hline 93-0200-073 & $\begin{array}{l}\text { W-211, Initial Tank Retrieval } \\
\text { Systems }\end{array}$ & III & $6 / 22 / 93$ & $\mathrm{~N} / \mathrm{A}$ & $\mathrm{N} / \mathrm{A}$ & $6 / 25 / 93$ & WHC & no known \\
\hline
\end{tabular}


Table A.1. (Contd)

\begin{tabular}{|c|c|c|c|c|c|c|c|c|}
\hline Case \# & Project Name & Class & $\begin{array}{c}\text { Date } \\
\text { Received }\end{array}$ & Survey & Monitoring & $\begin{array}{c}\text { Date } \\
\text { Completed }\end{array}$ & $\begin{array}{c}\text { Requesting } \\
\text { Organization }\end{array}$ & $\begin{array}{c}\text { Cultural } \\
\text { Resources? }\end{array}$ \\
\hline $93-0200-074$ & $\begin{array}{l}\text { Solid Waste Retrieval Complex, } \\
\text { Phase I (W-113) } \\
\text { Railroad Spur: }\end{array}$ & IIII/IV & $\begin{array}{l}6 / 25 / 93 \\
7 / 16 / 93\end{array}$ & $\begin{array}{l}2 / 3-2 / 5 / 88 \\
\text { needed }\end{array}$ & $\begin{array}{l}\text { N/A } \\
\text { N/A }\end{array}$ & $\begin{array}{l}6 / 28 / 93 \\
\text { FY } 1994\end{array}$ & WHC & $\begin{array}{l}\text { White } \\
\text { Bluffs Rd.-- } \\
\text { to be } \\
\text { avoided }\end{array}$ \\
\hline $93-0200-075$ & $\begin{array}{l}\text { Unvented Phase Drum Retrieval } \\
\text { and Container Venting }\end{array}$ & III & $6 / 25 / 93$ & $\mathrm{~N} / \mathrm{A}$ & N/A & $6 / 29 / 93$ & WHC & no known \\
\hline $93-0200-076$ & $\begin{array}{l}\text { Utility Traffic Box in } \\
\text { 241-T Farm }\end{array}$ & III & $6 / 28 / 93$ & N/A & N/A & $7 / 1 / 93$ & $\overline{\mathrm{WHC}}$ & no known \\
\hline $93-0200-077$ & $\begin{array}{l}\text { Demolition of Buildings } 2711 \text { S } \\
\& 2718 \text { S }\end{array}$ & VI & $6 / 28 / 93$ & $9 / 2 / 93$ & N/A & FY 1994 & WHC & $\begin{array}{l}1952 \\
\text { unknown }\end{array}$ \\
\hline $93-0200-078$ & $\begin{array}{l}\text { L-207, 10-Wide Trailer } \\
\text { Installation at } 222 \mathrm{~S}\end{array}$ & III & $7 / 1 / 93$ & $\mathrm{~N} / \mathrm{A}$ & N/A & $7 / 7 / 93$ & WHC & no known \\
\hline $93-0200-079$ & $\begin{array}{l}200 \text { Area KEH Security } \\
\text { Fencing--A Farm Area }\end{array}$ & III & $7 / 12 / 93$ & $\mathrm{~N} / \mathrm{A}$ & $\mathrm{N} / \mathrm{A}$ & $7 / 14 / 93$ & $\overline{\mathrm{KEH}}$ & no known \\
\hline $93-0200-080$ & $\begin{array}{l}200 \text { Area KEH Security } \\
\text { Fencing--Construction Complex }\end{array}$ & III & $7 / 12 / 93$ & $\mathrm{~N} / \mathrm{A}$ & N/A & $7 / 14 / 93$ & $\mathrm{KEH}$ & no known \\
\hline $93-0200-081$ & $\begin{array}{l}200 \text { Area KEH Security } \\
\text { Fencing--B-Plant }\end{array}$ & III & $7 / 12 / 93$ & $\mathrm{~N} / \mathrm{A}$ & N/A & $7 / 14 / 93$ & $\mathrm{KEH}$ & no known \\
\hline $93-0200-082$ & $\begin{array}{l}200 \text { Area KEH Security } \\
\text { Fencing--Well Drilling Yard }\end{array}$ & III & $7 / 12 / 93$ & $\mathrm{~N} / \mathrm{A}$ & N/A & $7 / 14 / 93$ & $\mathrm{KEH}$ & no known \\
\hline $93-0200-083$ & $\begin{array}{l}\text { Repair Eye Wash Station at } \\
\text { GPF Truck Unloading Area }\end{array}$ & $I$ & $7 / 12 / 93$ & N/A & N/A & $7 / 15 / 93$ & WHC & no known \\
\hline $93-0200-084$ & $\begin{array}{l}\text { Repair Cable in } \\
\text { 241-AN-105 Tank }\end{array}$ & $I$ & $7 / 12 / 93$ & N/A & N/A & $7 / 15 / 93$ & WHC & no known \\
\hline $93-0200-085$ & Install TMACS at $241 \mathrm{Bx}$ & III & $7 / 12 / 93$ & N/A & N/A & $7 / 13 / 93$ & WHC & no known \\
\hline
\end{tabular}


Table A.1. (Contd)

\begin{tabular}{|c|c|c|c|c|c|c|c|c|}
\hline Case \# & Project Name & Class & $\begin{array}{c}\text { Date } \\
\text { Received }\end{array}$ & Survey & Monitoring & \begin{tabular}{c|} 
Date \\
Completed
\end{tabular} & \begin{tabular}{|l} 
Requesting \\
Organization
\end{tabular} & $\begin{array}{c}\text { Cultural } \\
\text { Resources? }\end{array}$ \\
\hline $93-0200-086$ & $\begin{array}{l}\text { Training Trailer, } 200 \mathrm{~W}, \\
\text { MO-535 }\end{array}$ & III & $7 / 13 / 93$ & N/A & $\mathrm{N} / \mathrm{A}$ & $7 / 14 / 93$ & WHC & no known \\
\hline 93-0200-087 & 200 Areas Biota & III & $7 / 13 / 93$ & N/A & N/A & $7 / 16 / 93$ & WHC & no known \\
\hline $93-0200-088$ & 284W Alternate Brine System & III & $7 / 13 / 93$ & N/A & N/A & $7 / 16 / 93$ & WHC & no known \\
\hline $93-0200-089$ & PFP Ductwork Remediation & VI & $7 / 14 / 93$ & N/A & N/A & $7 / 20 / 93$ & WHC & $\begin{array}{l}\text { constructed } \\
1950\end{array}$ \\
\hline $93-0200-090$ & $\begin{array}{l}\text { 231Z HVAC Modifications } \\
\text { Additional Modifications: }\end{array}$ & VI & $\begin{array}{l}7 / 14 / 93 \\
7 / 21 / 93\end{array}$ & $\begin{array}{l}\text { N/A } \\
\text { N/A }\end{array}$ & $\begin{array}{l}\text { N/A } \\
\text { N/A }\end{array}$ & \begin{tabular}{|l|}
$7 / 16 / 93$ \\
$7 / 28 / 93$
\end{tabular} & $\overline{\text { WHC }}$ & $\begin{array}{l}\text { constructed } \\
1944\end{array}$ \\
\hline $93-0200-091$ & $\begin{array}{l}\text { Repair Security Fence at } \\
\text { 200E Main Gate }\end{array}$ & $I$ & $7 / 16 / 93$ & N/A & $\mathrm{N} / \mathrm{A}$ & $7 / 19 / 93$ & WHC & no known \\
\hline $93-0200-092$ & Repair of Atlantic Avenue & I & $7 / 15 / 93$ & N/A & N/A & $7 / 19 / 93$ & WHC & no known \\
\hline $93-0200-093$ & $\begin{array}{l}\text { C-134, T-Plant Parking Lot } \\
\text { Resurfacing \& Entry Way } \\
\text { Addition }\end{array}$ & I/III/VI & $7 / 20 / 93$ & N/A & $\mathrm{N} / \mathrm{A}$ & $7 / 21 / 93$ & WHC & no known \\
\hline $93-0200-094$ & $\begin{array}{l}\text { 233-S, Facility } \\
\text { Decommissioning Mobile } \\
\text { Trailers }\end{array}$ & III & $7 / 21 / 93$ & N/A & N/A & $8 / 9 / 93$ & WHC & no known \\
\hline $93-0200-095$ & $\begin{array}{l}\text { Less than } 90 \text { Day Hazardous } \\
\text { Storage Pad Guard Posts }\end{array}$ & III & $7 / 23 / 93$ & N/A & N/A & $7 / 26 / 93$ & $\overline{\text { WHC }}$ & no known \\
\hline $93-0200-096$ & $\begin{array}{l}\text { Install Pax Speakers in } \\
\text { 200W-PFP Bldg. 2721-Z }\end{array}$ & III & $7 / 23 / 93$ & N/A & $\mathrm{N} / \mathrm{A}$ & $7 / 26 / 93$ & WHC & no known \\
\hline 93-0200-097 & $\begin{array}{l}\text { Install TMACS in 241-AN \& } \\
\text { 241-T Tank Farms }\end{array}$ & III & $7 / 26 / 93$ & N/A & N/A & \begin{tabular}{|l|l|}
$7 / 27 / 93$ \\
\end{tabular} & WHC & no known \\
\hline $93-0200-098$ & $\begin{array}{l}\text { Install Blank on Raw Water } \\
\text { Line at 293-A Bldg }\end{array}$ & III & $7 / 27 / 93$ & N/A & N/A & $7 / 29 / 93$ & WHC & no known \\
\hline
\end{tabular}


Table A.1. (Contd)

\begin{tabular}{|c|c|c|c|c|c|c|c|c|}
\hline Case \# & Project Name & Class & $\begin{array}{c}\text { Date } \\
\text { Received }\end{array}$ & Survey & Monitoring & $\begin{array}{c}\text { Date } \\
\text { Completed }\end{array}$ & $\begin{array}{c}\text { Requesting } \\
\text { Organization }\end{array}$ & $\begin{array}{c}\text { Cultural } \\
\text { Resources? }\end{array}$ \\
\hline $93-0200-099$ & Repair Sanitary Water Valves & $\mathrm{I}$ & $7 / 27 / 93$ & N/A & N/A & $7 / 29 / 93$ & WHC & no known \\
\hline $93-0200-100$ & Tank 105A Tracer Study & III & $7 / 27 / 93$ & N/A & N/A & $7 / 29 / 93$ & $\mathrm{KEH}$ & no known \\
\hline $93-0200-101$ & Utilities for Maintenance Shop & III & $7 / 28 / 93$ & $\mathrm{~N} / \mathrm{A}$ & $\mathrm{N} / \mathrm{A}$ & $7 / 28 / 93$ & WHC & no known \\
\hline $93-0200-102$ & Sonic Drilling Test & III & $7 / 29 / 93$ & $\mathrm{~N} / \mathrm{A}$ & $\mathrm{N} / \mathrm{A}$ & $7 / 29 / 93$ & WHC & no known \\
\hline $93-0200-103$ & 222S Laboratory Upgrades & VI & $7 / 29 / 93$ & $\mathrm{~N} / \mathrm{A}$ & N/A & $7 / 29 / 93$ & WHC & $\begin{array}{l}\text { constructed } \\
1952\end{array}$ \\
\hline $93-0200-104$ & $\begin{array}{l}\text { Jet Shot Perforation on } \\
\text { Well 299-W18-19 }\end{array}$ & III & $7 / 28 / 93$ & N/A & N/A & $8 / 2 / 93$ & WHC & no known \\
\hline $93-0200-105$ & $\begin{array}{l}\text { W-312--Flammable Storage } \\
\text { Modules }\end{array}$ & III & $7 / 30 / 93$ & done 1990 & $\mathrm{~N} / \mathrm{A}$ & $8 / 2 / 93$ & WHC & no known \\
\hline $93-0200-106$ & PFP Canyon Doors Reinforcing & VI & $8 / 2 / 93$ & N/A & N/A & $8 / 4 / 93$ & WHC & $\begin{array}{l}\text { constructed } \\
1950\end{array}$ \\
\hline $93-0200-107$ & PFP Office Conversion & $\mathrm{VI}$ & $8 / 2 / 93$ & N/A & $\mathrm{N} / \mathrm{A}$ & $8 / 4 / 93$ & WHC & $\begin{array}{l}\text { constructed } \\
1950\end{array}$ \\
\hline $93-0200-108$ & 241-SY Air Supply Line & III & $8 / 2 / 93$ & $\mathrm{~N} / \mathrm{A}$ & $\mathrm{N} / \mathrm{A}$ & $8 / 4 / 93$ & WHC & no known \\
\hline $93-0200-109$ & $\begin{array}{l}\text { In-Well Sparging Treatability } \\
\text { Demonstration in } 200 \mathrm{~W}\end{array}$ & III & $8 / 4 / 93$ & N/A & $\mathrm{N} / \mathrm{A}$ & $8 / 5 / 93$ & WHC & no known \\
\hline $93-0200-110$ & $\begin{array}{l}\text { 200W Carbon Tetrachloride } \\
\text { Expedited Response Action }\end{array}$ & III & $8 / 4 / 93$ & $\mathrm{~N} / \mathrm{A}$ & N/A & $8 / 5 / 93$ & WHC & no known \\
\hline $93-0200-111$ & $\begin{array}{l}\text { Project W-320, } \\
\text { Tank 241-C-106 Sluicing }\end{array}$ & III & $8 / 4 / 93$ & N/A & $\mathrm{N} / \mathrm{A}$ & $8 / 9 / 93$ & WHC & no known \\
\hline $93-0200-112$ & \begin{tabular}{|l} 
Interim Stabilization of \\
218-E-12A Burial Ground
\end{tabular} & III & $8 / 5 / 93$ & N/A & $\mathrm{N} / \mathrm{A}$ & $8 / 6 / 93$ & WHC & no known \\
\hline $93-0200-113$ & Hot Yard Clean Up & III & $8 / 6 / 93$ & N/A & N/A & $8 / 9 / 93$ & $\mathrm{KEH}$ & no known \\
\hline
\end{tabular}


Table A.1. (Contd)

\begin{tabular}{|c|c|c|c|c|c|c|c|c|}
\hline Case \# & Project Name & Class & $\begin{array}{c}\text { Date } \\
\text { Received }\end{array}$ & Survey & Monitoring & \begin{tabular}{|c|} 
Date \\
Completed
\end{tabular} & \begin{tabular}{|c|} 
Requesting \\
Organization
\end{tabular} & $\begin{array}{c}\text { Cultural } \\
\text { Resources? }\end{array}$ \\
\hline $93-0200-114$ & $\begin{array}{l}\text { Mobile Office Installation-- } \\
\text { MO-955 }\end{array}$ & III & $8 / 6 / 93$ & N/A & $\mathrm{N} / \mathrm{A}$ & $8 / 9 / 93$ & KEH & no known \\
\hline $93-0200-115$ & Nitric Acid Tank Kiosk & III & $8 / 9 / 93$ & $\mathrm{~N} / \mathrm{A}$ & N/A & $8 / 10 / 93$ & WHC & no known \\
\hline $93-0200-116$ & $\begin{array}{l}\text { C-116 Borehole Test for } \\
\text { Contamination }\end{array}$ & III & $8 / 9 / 93$ & $\mathrm{~N} / \mathrm{A}$ & $\mathrm{N} / \mathrm{A}$ & $8 / 10 / 93$ & WHC & no known \\
\hline $93-0200-117$ & T-Plant Sign and Flagpole & III & $8 / 10 / 93$ & N/A & N/A & $8 / 10 / 93$ & WHC & no known \\
\hline $93-0200-118$ & $\begin{array}{l}\text { 222-S Building Interior } \\
\text { Modifications }\end{array}$ & VI & $8 / 11 / 93$ & N/A & N/A & $8 / 17 / 93$ & WHC & $\begin{array}{l}\text { constructed } \\
1952\end{array}$ \\
\hline $93-0200-119$ & Excavate to Repair PIV 1785 & $I$ & $8 / 11 / 93$ & N/A & $\mathrm{N} / \mathrm{A}$ & $8 / 18 / 93$ & WHC & no known \\
\hline $93-0200-120$ & $\begin{array}{l}\text { Excavate to Repair GIV for } \\
\text { Hydrant 9-E }\end{array}$ & $I$ & $8 / 11 / 93$ & N/A & $\mathrm{N} / \mathrm{A}$ & $8 / 18 / 93$ & WHC & no known \\
\hline $93-0200-121$ & $\begin{array}{l}\text { Replace Compressed Air } \\
\text { System in } 241-U-701\end{array}$ & III & $8 / 16 / 93$ & N/A & N/A & $8 / 19 / 93$ & WHC & no known \\
\hline $93-0200-122$ & PFP Chemical Storage Trailers & III & $8 / 16 / 93$ & N/A & $\mathrm{N} / \mathrm{A}$ & $8 / 19 / 93$ & WHC & no known \\
\hline $93-0200-123$ & $\begin{array}{l}\text { 241-S New Lit Installation } \\
107-S\end{array}$ & III & $8 / 16 / 93$ & N/A & N/A & $8 / 19 / 93$ & WHC & no known \\
\hline $93-0200-124$ & $\begin{array}{l}\text { Demolition of High Water } \\
\text { Tanks, } 200 \mathrm{E} \text { and W }\end{array}$ & III/VI & $8 / 18 / 93$ & N/A & $\mathrm{N} / \mathrm{A}$ & $8 / 31 / 93$ & WHC & $\begin{array}{l}\text { constructed } \\
1940 \text { s }\end{array}$ \\
\hline $93-0200-125$ & Utility Installation & III & $8 / 19 / 93$ & $\mathrm{~N} / \mathrm{A}$ & N/A & $8 / 24 / 93$ & WHC & no known \\
\hline $93-0200-126$ & $\begin{array}{l}\text { Project W-291H, } 200 \text { Area } \\
\text { Effluent Bat/Akart } \\
\text { Implementation }\end{array}$ & III & $8 / 20 / 93$ & $\mathrm{~N} / \mathrm{A}$ & $\mathrm{N} / \mathrm{A}$ & $8 / 25 / 93$ & WHC & no known \\
\hline $93-0200-127$ & $\begin{array}{l}\text { Remove Temporary Anchors } \\
\text { from 241-SY Tank Farm }\end{array}$ & III & $8 / 20 / 93$ & N/A & N/A & $8 / 24 / 93$ & WHC & no known \\
\hline $93-0200-128$ & $200-Z P-1$ & III & $8 / 20 / 93$ & N/A & N/A & $8 / 25 / 93$ & WHC & no known \\
\hline
\end{tabular}


Table A.1. (Contd)

\begin{tabular}{|c|c|c|c|c|c|c|c|c|}
\hline Çase \# & Project Name & Class & $\begin{array}{c}\text { Date } \\
\text { Received }\end{array}$ & Survey & Monitoring & $\begin{array}{c}\text { Date } \\
\text { Completed }\end{array}$ & $\begin{array}{c}\text { Requesting } \\
\text { Organization }\end{array}$ & $\begin{array}{c}\text { Cultural } \\
\text { Resources? }\end{array}$ \\
\hline $93-0200-129$ & $\begin{array}{l}\text { PFP-Modification of RAM } \\
\text { Station }\end{array}$ & VI & $8 / 25 / 93$ & N/A & $\mathrm{N} / \mathrm{A}$ & $8 / 31 / 93$ & WHC & $\begin{array}{l}\text { constructed } \\
1950\end{array}$ \\
\hline $93-0200-130$ & $\begin{array}{l}\text { PFP Insulator Shop } \\
\text { Modifications }\end{array}$ & VI & $8 / 25 / 93$ & N/A & N/A & $8 / 31 / 93$ & WHC & $\begin{array}{l}\text { constructed } \\
1950\end{array}$ \\
\hline $93-0200-131$ & Gas Bottle Storage Upgrade & VI & $8 / 25 / 93$ & N/A & N/A & $8 / 31 / 93$ & WHC & $\begin{array}{l}\text { constructed } \\
1949\end{array}$ \\
\hline $93-0200-132$ & 231-Z Reroofing & VI & $8 / 24 / 93$ & $\mathrm{~N} / \mathrm{A}$ & $\mathrm{N} / \mathrm{A}$ & $9 / 8 / 93$ & WHC & $\begin{array}{l}\text { constructed } \\
1944\end{array}$ \\
\hline $93-0200-133$ & $\begin{array}{l}\text { Chemical Storage Bldg for } \\
\text { 2703E Chem. Engineering Lab }\end{array}$ & III & $8 / 26 / 93$ & $\mathrm{~N} / \mathrm{A}$ & N/A & $9 / 1 / 93$ & WHC & no known \\
\hline $93-0200-134$ & $\begin{array}{l}\text { Baltimore Ave. Entrance } \\
\text { Modifications }\end{array}$ & III & $8 / 27 / 93$ & N/A & N/A & $9 / 1 / 93$ & WHC & no known \\
\hline $93-0200-135$ & $\begin{array}{l}\text { Special Case Waste Near-Term } \\
\text { Storage Modules (W-272) }\end{array}$ & III & $8 / 27 / 93$ & in 1990 & N/A & $9 / 3 / 93$ & WHC & none found \\
\hline $93-0200-136$ & $\begin{array}{l}\text { L-116, } 200 \text { Area Sanitary } \\
\text { Sewer System }\end{array}$ & III/V & $8 / 27 / 93$ & needed & $?$ & FY 1994 & WHC & \\
\hline $93-0200-137$ & W-026, WRAP I Facility & III & $8 / 30 / 93$ & in 1990 & N/A & $9 / 8 / 93$ & WHC & none found \\
\hline $93-0200-138$ & $\begin{array}{l}\text { Repair } 200 \text { Area General High } \\
\text { Tank Overflow Piping }\end{array}$ & III & $9 / 2 / 93$ & $\mathrm{~N} / \mathrm{A}$ & N/A & $9 / 3 / 93$ & WHC & no known \\
\hline $93-0200-139$ & Gen Hydro Waste Transfer Line & $\mathrm{I}$ & $9 / 1 / 93$ & N/A & N/A & $9 / 3 / 93$ & WHC & no known \\
\hline $93-0200-140$ & $\begin{array}{l}\text { 95L-EWW-252, Phase II Liquid } \\
\text { Effluent Treatment \& Disposal }\end{array}$ & III/VI & $8 / 30 / 93$ & $\begin{array}{l}\text { Blg. doc. } \\
\text { needed }\end{array}$ & N/A & $\begin{array}{l}\text { 9/27/93 } \\
\text { (not bldg. } \\
\text { demo) }\end{array}$ & WHC & $\begin{array}{l}\text { none } \\
\text { affected }\end{array}$ \\
\hline $93-0200-141$ & $\begin{array}{l}\text { 200-BP-5 Operable Unit } \\
\text { Treatability Test }\end{array}$ & III & $8 / 30 / 93$ & N/A & N/A & $9 / 8 / 93$ & WHC & no known \\
\hline
\end{tabular}


Table A.1. (Contd)

\begin{tabular}{|c|c|c|c|c|c|c|c|c|}
\hline Case \# & Project Name & Class & $\begin{array}{c}\text { Date } \\
\text { Received }\end{array}$ & Survey & Monitoring & \begin{tabular}{|c|} 
Date \\
Completed
\end{tabular} & \begin{tabular}{|c|} 
Requesting \\
Organization
\end{tabular} & $\begin{array}{c}\text { Cultural } \\
\text { Resources? }\end{array}$ \\
\hline $93-0200-142$ & $\operatorname{Re}-\operatorname{Roof} 2711-\mathrm{E}$ & VI & $8 / 31 / 93$ & N/A & $\mathrm{N} / \mathrm{A}$ & $9 / 8 / 93$ & WHC & $\begin{array}{l}\text { constructed } \\
1984\end{array}$ \\
\hline $93-0200-143$ & $\begin{array}{l}\text { Demolition of W-19 Bldg \& } \\
\text { Siting of Construction Shop }\end{array}$ & VI & $9 / 1 / 93$ & $12 / 1 / 93$ & $\mathrm{~N} / \mathrm{A}$ & FY 1994 & $\overline{\text { WHC }}$ & $\begin{array}{l}\text { constructed } \\
1954, \text { not } \\
\text { eligible }\end{array}$ \\
\hline $93-0200-144$ & $\begin{array}{l}\text { 2607-W1 Drainfield System } \\
\text { Installation }\end{array}$ & III & $9 / 2 / 93$ & N/A & $\mathrm{N} / \mathrm{A}$ & $9 / 13 / 93$ & WHC & no known \\
\hline $93-0200-145$ & 2711-E Replace Roof Deck & VI & $9 / 3 / 93$ & N/A & $\mathrm{N} / \mathrm{A}$ & $9 / 14 / 93$ & WHC & $\begin{array}{l}\text { constructed } \\
1984\end{array}$ \\
\hline $93-0200-146$ & $\begin{array}{l}\text { 272E Bldg Copy Room } \\
\text { Modifications/Demolition }\end{array}$ & VI & $9 / 7 / 93$ & N/A & N/A & $9 / 14 / 93$ & WHC & $\begin{array}{l}\text { constructed } \\
1944, \text { not } \\
\text { eligible }\end{array}$ \\
\hline $93-0200-147$ & $\begin{array}{l}\text { 291-T Steam Line Support } \\
\text { Removal }\end{array}$ & I & $9 / 3 / 93$ & N/A & N/A & $9 / 13 / 93$ & WHC & no known \\
\hline $93-0200-148$ & 271-U Power Pole Installation & I & $9 / 15 / 93$ & N/A & N/A & $9 / 15 / 93$ & WHC & no known \\
\hline $93-0200-149$ & $\begin{array}{l}\text { Excavate to Repair Ground } \\
\text { Valve for Hydrant 2-B }\end{array}$ & $\bar{I}$ & $9 / 8 / 93$ & N/A & $\mathrm{N} / \mathrm{A}$ & $9 / 15 / 93$ & WHC & no known \\
\hline $93-0200-150$ & $\begin{array}{l}\text { Replace Compressed Air } \\
\text { System 241-T-701 }\end{array}$ & I & $9 / 8 / 93$ & N/A & N/A & $9 / 15 / 93$ & WHC & no known \\
\hline $93-0200-151$ & $\begin{array}{l}\text { 233-S Facility } \\
\text { Decommissioning }\end{array}$ & VI & $9 / 8 / 93$ & \multicolumn{3}{|c|}{ Complete in FY 1994} & WHC & \\
\hline $93-0200-152$ & $\begin{array}{l}\text { 232-Z Waste Incinerator } \\
\text { Facility Decommissioning }\end{array}$ & VI & $9 / 8 / 93$ & \multicolumn{3}{|c|}{ Complete in FY 1994} & WHC & \\
\hline $93-0200-153$ & Air Line at 241-SY & I & $9 / 13 / 93$ & N/A & N/A & $9 / 15 / 93$ & WHC & no known \\
\hline $93-0200-154$ & $\begin{array}{l}\text { Central Waste Complex \& } \\
\text { TRUSAF Paving }\end{array}$ & III & $9 / 10 / 93$ & N/A & N/A & $9 / 15 / 93$ & WHC & no known \\
\hline
\end{tabular}


Table A.1. (Contd)

\begin{tabular}{|c|c|c|c|c|c|c|c|c|}
\hline Case \# & Project Name & Class & $\begin{array}{c}\text { Date } \\
\text { Received }\end{array}$ & Survey & Monitoring & $\begin{array}{c}\text { Date } \\
\text { Completed }\end{array}$ & \begin{tabular}{|c|} 
Requesting \\
Organization
\end{tabular} & $\begin{array}{c}\text { Cultural } \\
\text { Resources? }\end{array}$ \\
\hline $93-0200-155$ & $\begin{array}{l}\text { Excavate to Expose } \\
\text { Hydrant 4-S Drain Ports }\end{array}$ & I & $9 / 13 / 93$ & N/A & N/A & $9 / 16 / 93$ & WHC & no known \\
\hline $93-0200-156$ & 200-UP-1 & I & $9 / 14 / 93$ & $\mathrm{~N} / \mathrm{A}$ & $\mathrm{N} / \mathrm{A}$ & $9 / 16 / 93$ & WHC & no known \\
\hline $93-0200-157$ & $\begin{array}{l}10 \text {-Wide Mobile Office in } \\
200 \mathrm{~W}\end{array}$ & III & $9 / 16 / 93$ & N/A & $\mathrm{N} / \mathrm{A}$ & $9 / 20 / 93$ & WHC & no known \\
\hline $93-0200-158$ & $\begin{array}{l}\text { In-Situ Bioremediation Volatile } \\
\text { Organic Compound-Arid } \\
\text { Integrated Wells }\end{array}$ & III & $9 / 20 / 93$ & N/A & N/A & $9 / 20 / 93$ & WHC & no known \\
\hline $93-0200-159$ & $2 X-93-00113$ & III & $9 / 15 / 93$ & N/A & N/A & $9 / 20 / 93$ & WHC & no known \\
\hline $93-0200-160$ & $\begin{array}{l}\text { Paint Exterior \& Trim of } \\
\text { 275E Bldg }\end{array}$ & VI & $9 / 20 / 93$ & N/A & $\mathrm{N} / \mathrm{A}$ & $9 / 22 / 93$ & WHC & $\begin{array}{l}\text { constructed } \\
1944\end{array}$ \\
\hline $93-0200-161$ & W-363, 272WA Septic Upgrade & III/IV & $9 / 20 / 93$ & $\mathrm{~N} / \mathrm{A}$ & N/A & $9 / 27 / 93$ & WHC & Site 3-47 \\
\hline $93-0200-162$ & $\begin{array}{l}\text { Project L-173, 200W First Aid } \\
\text { Station }\end{array}$ & III & $9 / 22 / 93$ & $\mathrm{~N} / \mathrm{A}$ & N/A & $9 / 22 / 93$ & WHC & no known \\
\hline $93-0200-163$ & $\begin{array}{l}\text { Water Lines to New MO } \\
(200 \mathrm{~W})\end{array}$ & III & $9 / 22 / 93$ & $\mathrm{~N} / \mathrm{A}$ & N/A & $9 / 24 / 93$ & WHC & no known \\
\hline $93-0200-164$ & PUREX Conduit Trench & III & $9 / 24 / 93$ & N/A & N/A & $9 / 24 / 93$ & WHC & no known \\
\hline $93-0300-001$ & Lab Rehab, Phase I, 331 Bldg & III/VI & $12 / 23 / 92$ & N/A & N/A & $2 / 2 / 93$ & PNL & no known \\
\hline $93-0300-002$ & 324 Facility Compliance/Ren. & II & $1 / 15 / 93$ & N/A & $\mathrm{N} / \mathrm{A}$ & $2 / 2 / 93$ & PNL & no known \\
\hline $93-0300-003$ & Sink Hole South of 328 Bldg. & II & $1 / 11 / 93$ & N/A & N/A & $2 / 2 / 93$ & WHC & no known \\
\hline $93-0300-004$ & Repair Underground Leak 306E & II & $1 / 11 / 93$ & $\mathrm{~N} / \mathrm{A}$ & N/A & $2 / 2 / 93$ & WHC & no known \\
\hline $93-0300-005$ & $\begin{array}{l}\text { D-440 National Security Tech. } \\
\text { Center }\end{array}$ & $\mathrm{V}$ & $1 / 23 / 93$ & $1989 \& 90$ & N/A & $4 / 15 / 93$ & PNL & no known \\
\hline $93-0300-006$ & $\begin{array}{l}\text { Door Mods Room 15A, } \\
329 \text { Bldg. }\end{array}$ & II & $1 / 29 / 93$ & N/A & N/A & $2 / 4 / 93$ & PNL & $\begin{array}{l}\text { constructed } \\
1952\end{array}$ \\
\hline
\end{tabular}


Table A.1. (Contd)

\begin{tabular}{|c|c|c|c|c|c|c|c|c|}
\hline Case \# & Project Name & Class & $\begin{array}{l}\text { Date } \\
\text { Received }\end{array}$ & Survey & Monitoring & \begin{tabular}{|c|} 
Date \\
Completed
\end{tabular} & $\begin{array}{c}\text { Requesting } \\
\text { Organization }\end{array}$ & $\begin{array}{c}\text { Cultural } \\
\text { Resources? }\end{array}$ \\
\hline $93-0300-007$ & $\begin{array}{l}300 \text { Area Fire Station Well } \\
\text { Installations }\end{array}$ & III & $2 / 11 / 93$ & $\mathrm{~N} / \mathrm{A}$ & N/A & $2 / 17 / 93$ & WHC & no known \\
\hline $93-0300-008$ & Paved Access for 305B Facility & $I$ & $2 / 26 / 93$ & N/A & N/A & $3 / 22 / 93$ & WHC & no known \\
\hline $93-0300-009$ & $\begin{array}{l}\text { Demolition of Bldgs. 3701, } \\
\text { 3701-A }\end{array}$ & VI & $3 / 5 / 93$ & $8 / 26 / 93$ & N/A & & WHC & $\overline{1981}$ \\
\hline $93-0300-010$ & 301 Building Demolition & VI & $3 / 22 / 93$ & $7 / 26 / 93$ & N/A & $9 / 1 / 93$ & WHC & not eligible \\
\hline $93-0300-011$ & EMSL Temporary Facilities & $\mathrm{V}$ & $3 / 15 / 93$ & $\overline{1991}$ & N/A & $4 / 13 / 93$ & KEH & no known \\
\hline $93-0300-012$ & Fire Hydrant FH-15 Repair & $I$ & $3 / 26 / 93$ & N/A & N/A & $4 / 9 / 93$ & WHC & no known \\
\hline $93-0300-013$ & $\begin{array}{l}\text { Emergency Water Line Repair } \\
\text { at the } 324 \mathrm{Bldg}\end{array}$ & $I$ & $4 / 9 / 93$ & $\overline{\text { N/A }}$ & N/A & $4 / 9 / 93$ & WHC & no known \\
\hline $93-0300-014$ & $\begin{array}{l}\text { Stack Sampling Upgrades, } \\
\text { 324 Bldg. }\end{array}$ & III & $4 / 9 / 93$ & $\overline{\mathrm{N} / \mathrm{A}}$ & N/A & $4 / 15 / 93$ & PNL & no known \\
\hline $93-0300-015$ & \begin{tabular}{|l}
382 Soil-Gas Survey \\
\end{tabular} & III & $4 / 14 / 93$ & N/A & N/A & $4 / 16 / 93$ & WHC & no known \\
\hline $93-0300-016$ & $\begin{array}{l}\text { Replace Condensate Line NW } \\
\text { of } 3722 \text { Building }\end{array}$ & $I$ & $4 / 15 / 93$ & $\overline{\mathrm{N} / \mathrm{A}}$ & N/A & $4 / 30 / 93$ & WHC & no known \\
\hline $93-0300-017$ & $\begin{array}{l}\text { T Plant Facility Upgrades, } \\
\text { Projects W-335, W-336, W-337 }\end{array}$ & VI & $4 / 13 / 93$ & $\mathrm{~N} / \mathrm{A}$ & N/A & $5 / 5 / 93$ & WHC & $\begin{array}{l}\text { constructed } \\
1952\end{array}$ \\
\hline $93-0300-018$ & $\begin{array}{l}300 \text { Fuels Fabrication Facilities } \\
\text { Stabilization }\end{array}$ & VI & $4 / 28 / 93$ & \multicolumn{3}{|c|}{ Complete in FY 1994} & WHC & \\
\hline $93-0300-019$ & $\begin{array}{l}\text { Repair Underground Water } \\
\text { Line NE of } 327 \text { Bldg. }\end{array}$ & $I$ & $5 / 6 / 93$ & $\overline{N / A}$ & $\mathrm{~N} / \mathrm{A}$ & $5 / 11 / 93$ & WHC & no known \\
\hline $93-0300-020$ & \begin{tabular}{|l|}
300 Area, George Wash. Way \\
Entrance Modifications Building \\
Demolition (on bottom):
\end{tabular} & I/III & $5 / 3 / 93$ & N/A & N/A & $\begin{array}{l}6 / 3 / 93 \\
7 / 12 / 93\end{array}$ & WHC & no known \\
\hline
\end{tabular}


Table A.1. (Contd)

\begin{tabular}{|c|c|c|c|c|c|c|c|c|}
\hline Case \# & Project Name & Class & $\begin{array}{c}\text { Date } \\
\text { Received }\end{array}$ & Survey & Monitoring & \begin{tabular}{c|} 
Date \\
Completed
\end{tabular} & $\begin{array}{l}\text { Requesting } \\
\text { Organization }\end{array}$ & $\begin{array}{c}\text { Cultural } \\
\text { Resources? }\end{array}$ \\
\hline $93-0300-021$ & $\begin{array}{l}300 \text { Area, Cypress St. Entrance } \\
\text { Modifications Building } \\
\text { Demolition (on bottom): }\end{array}$ & $\mathrm{I} / \mathrm{III}$ & $5 / 3 / 93$ & N/A & N/A & $\begin{array}{l}6 / 3 / 93 \\
7 / 12 / 93\end{array}$ & WHC & no known \\
\hline $93-0300-022$ & $\begin{array}{l}300 \text { Area First Aid Station } \\
\text { Loc. } \# 2 \text { : }\end{array}$ & III & $\begin{array}{l}5 / 12 / 93 \\
7 / 13 / 93\end{array}$ & $\begin{array}{l}\text { N/A } \\
\text { N/A }\end{array}$ & $\begin{array}{l}\text { N/A } \\
\text { N/A }\end{array}$ & $\begin{array}{l}5 / 20 / 93 \\
7 / 13 / 93\end{array}$ & WHC & $\begin{array}{l}\text { no known } \\
\text { no known }\end{array}$ \\
\hline $93-0300-023$ & 300 FFI Soil Washing Test & IV & $5 / 19 / 93$ & N/A & N/A & $6 / 8 / 93$ & WHC & no known \\
\hline $93-0300-024$ & $\begin{array}{l}\text { Marker Posts Around } \\
\text { 316-1/316-2 Process Ponds - } \\
300 \text { Area }\end{array}$ & IV/V & $5 / 24 / 93$ & $\begin{array}{l}1987 \& \\
1988\end{array}$ & needed & & WHC & \\
\hline $93-0300-025$ & $\begin{array}{l}\text { CR 1081-New Fence on No. \& } \\
\text { So. of Bldg } 328\end{array}$ & III & $5 / 24 / 93$ & N/A & N/A & $5 / 24 / 93$ & WHC & no known \\
\hline $93-0300-026$ & $\begin{array}{l}\text { Isolate } 308 \text { Bldg. from } \\
\text { Retention Process Sewer }\end{array}$ & $\mathrm{I}$ & $6 / 1 / 93$ & N/A & N/A & $6 / 4 / 93$ & WHC & no known \\
\hline $93-0300-027$ & $\begin{array}{l}305 \text { Building P.I.V. } \\
\text { Replacement }\end{array}$ & I & $6 / 7 / 93$ & N/A & N/A & $6 / 11 / 93$ & WHC & no known \\
\hline $93-0300-028$ & City of Richland Option & III & $6 / 8 / 93$ & $5 / 21 / 93$ & N/A & $6 / 14 / 93$ & WHC & none found \\
\hline $93-0300-029$ & $\begin{array}{l}\text { 300-FF-5 Groundwater Well } \\
\text { Remediation/Decommissioning }\end{array}$ & $\mathrm{I} / \mathrm{II}$ & $6 / 8 / 93$ & N/A & $8 / 13 / 93$ & $8 / 18 / 93$ & WHC & none found \\
\hline $93-0300-030$ & $\begin{array}{l}\text { E017 } 300 \text { Area Coal Handling } \\
\text { Upgrades }\end{array}$ & I/III & $6 / 9 / 93$ & N/A & N/A & $6 / 16 / 93$ & WHC & no known \\
\hline $93-0300-031$ & $\begin{array}{l}\text { Replace } 2 \text { Valve at FMIT } \\
\text { Laydown Yard }\end{array}$ & $I$ & $6 / 9 / 93$ & N/A & N/A & $6 / 16 / 93$ & WHC & no known \\
\hline $93-0300-032$ & 3762 Fire Alarm Upgrade & $I$ & $6 / 14 / 93$ & N/A & N/A & $6 / 17 / 93$ & PNL & no known \\
\hline $93-0300-033$ & $\begin{array}{l}\text { 94G-EWL-119, } 384 \text { Bldg. } \\
\text { Power House Upgrades }\end{array}$ & VI & $6 / 14 / 93$ & N/A & N/A & $6 / 18 / 93$ & WHC & $\begin{array}{l}\text { constructed } \\
1944\end{array}$ \\
\hline
\end{tabular}


Table A.1. (Contd)

\begin{tabular}{|c|c|c|c|c|c|c|c|c|}
\hline Case \# & Project Name & Class & $\begin{array}{c}\text { Date } \\
\text { Received }\end{array}$ & Survey & Monitoring & $\begin{array}{c}\text { Date } \\
\text { Completed }\end{array}$ & $\begin{array}{l}\text { Requesting } \\
\text { Organization }\end{array}$ & $\begin{array}{c}\text { Cultural } \\
\text { Resources? }\end{array}$ \\
\hline $93-0300-034$ & $\begin{array}{l}\text { 3U-93-00496/Install } \\
\text { Handicapped Parking Signs }\end{array}$ & III & $6 / 16 / 93$ & N/A & N/A & $6 / 18 / 93$ & WHC & no known \\
\hline $93-0300-035$ & $\begin{array}{l}313 \text { Building Steam Condensate } \\
\text { Rerouting }\end{array}$ & $\mathrm{VI}$ & $6 / 18 / 93$ & N/A & N/A & $8 / 5 / 93$ & WHC & $\begin{array}{l}\text { constructed } \\
1943\end{array}$ \\
\hline $93-0300-036$ & $\begin{array}{l}\text { Leaking } 3 \text { Condensate Line, } \\
\text { 306E Bldg. }\end{array}$ & $\mathrm{I}$ & $6 / 21 / 93$ & N/A & N/A & $6 / 24 / 93$ & WHC & no known \\
\hline $93-0300-037$ & $\begin{array}{l}\text { Project L-203, 315/ } \\
384 \text { Building Outfall Extension }\end{array}$ & $\mathrm{V}$ & $6 / 21 / 93$ & $1 / 11 / 90$ & needed & & WHC & \\
\hline $93-0300-038$ & Sinkhole East of 3712 Building & III & $6 / 25 / 93$ & N/A & N/A & $6 / 25 / 93$ & WHC & no known \\
\hline $93-0300-039$ & 340 Support Trailer & III & $6 / 28 / 93$ & N/A & N/A & $6 / 29 / 93$ & WHC & no known \\
\hline $93-0300-040$ & $\begin{array}{l}\text { Project L-125, } 300 \text { Area Storm } \\
\text { Drain Upgrades }\end{array}$ & I/III & $6 / 21 / 93$ & N/A & N/A & $7 / 6 / 93$ & WHC & no known \\
\hline $93-0300-041$ & $\begin{array}{l}\text { 3703 Building Exterior Siding } \\
\text { Installation }\end{array}$ & VI & $7 / 9 / 93$ & N/A & N/A & $7 / 15 / 93$ & WHC & $\begin{array}{l}\text { constructed } \\
1944\end{array}$ \\
\hline $93-0300-042$ & $\begin{array}{l}3703 \text { Building Air Conditioner } \\
\text { Installation }\end{array}$ & VI & $7 / 9 / 93$ & N/A & N/A & $7 / 15 / 93$ & WHC & $\begin{array}{l}\text { constructed } \\
1944\end{array}$ \\
\hline $93-0300-043$ & $\begin{array}{l}300 \text { Area Solvent Evaporator } \\
\text { Soil Sampling Project }\end{array}$ & III & $7 / 13 / 93$ & N/A & N/A & $7 / 16 / 93$ & WHC & no known \\
\hline 93-0300-044 & 384 Building Structural Repairs & VI & $7 / 21 / 93$ & N/A & N/A & $7 / 22 / 93$ & WHC & $\begin{array}{l}\text { constructed } \\
1944\end{array}$ \\
\hline $93-0300-045$ & $\begin{array}{l}\text { Install Latch Post at } \\
328 \text { Building }\end{array}$ & III & $7 / 22 / 93$ & N/A & N/A & $7 / 23 / 93$ & WHC & no known \\
\hline $93-0300-046$ & $\begin{array}{l}307 \text { Basin Maintenance } \\
\text { Activities/340 Complex }\end{array}$ & III & $7 / 26 / 93$ & $\mathrm{~N} / \mathrm{A}$ & N/A & $7 / 27 / 93$ & WHC & no known \\
\hline $93-0300-047$ & Field Screening Support Facility & III & $8 / 3 / 93$ & $\mathrm{~N} / \mathrm{A}$ & $\mathrm{N} / \mathrm{A}$ & $8 / 4 / 93$ & WHC & no known \\
\hline
\end{tabular}


Table A.1. (Contd)

\begin{tabular}{|c|c|c|c|c|c|c|c|c|}
\hline Case \# & Project Name & Class & $\begin{array}{c}\text { Date } \\
\text { Received }\end{array}$ & Survey & Monitoring & \begin{tabular}{|c|} 
Date \\
Completed
\end{tabular} & $\begin{array}{l}\text { Requesting } \\
\text { Organization }\end{array}$ & $\begin{array}{c}\text { Cultural } \\
\text { Resources? }\end{array}$ \\
\hline $93-0300-048$ & $\begin{array}{l}\text { Building Addition, } 318 \text { Bldg. } \\
\text { D-439 }\end{array}$ & III & $8 / 11 / 93$ & N/A & $\mathrm{N} / \mathrm{A}$ & $8 / 16 / 93$ & PNL & no known \\
\hline $93-0300-049$ & Diverter Valve Upgrade W-353 & VI & $8 / 11 / 93$ & N/A & $\mathrm{N} / \mathrm{A}$ & $8 / 16 / 93$ & WHC & $\begin{array}{l}\text { constructed } \\
1950 \text { s }\end{array}$ \\
\hline $93-0300-050$ & 331/U-3 Deep Pit & $\bar{I}$ & $8 / 12 / 93$ & N/A & $\mathrm{N} / \mathrm{A}$ & $8 / 17 / 93$ & WHC & no known \\
\hline $93-0300-051$ & Irrigation Repair & III & $8 / 18 / 93$ & N/A & $\mathrm{N} / \mathrm{A}$ & $8 / 19 / 93$ & WHC & no known \\
\hline $93-0300-052$ & $\begin{array}{l}\text { 3717, Structural Repairs \& } \\
\text { Reroofing }\end{array}$ & $\overline{\mathrm{VI}}$ & $8 / 19 / 93$ & N/A & $\mathrm{N} / \mathrm{A}$ & $8 / 24 / 93$ & $\overline{\mathrm{KEH}}$ & $\begin{array}{l}\text { constructed } \\
1944\end{array}$ \\
\hline $93-0300-053$ & 3705 Reroofing & VI & $8 / 19 / 93$ & N/A & $\mathrm{N} / \mathrm{A}$ & $8 / 24 / 93$ & KEH & $\begin{array}{l}\text { constructed } \\
1950\end{array}$ \\
\hline $93-0300-054$ & Reroof the 325 Building & VI & $8 / 19 / 93$ & N/A & N/A & $8 / 24 / 93$ & KEH & $\begin{array}{l}\text { constructed } \\
1953\end{array}$ \\
\hline $93-0300-055$ & $\begin{array}{l}333 \text { Bldg. Repair Roof } \\
\text { Membrane }\end{array}$ & $\overline{\mathrm{VI}}$ & $8 / 19 / 93$ & N/A & $\mathrm{N} / \mathrm{A}$ & $8 / 24 / 93$ & $\overline{\mathrm{KEH}}$ & $\begin{array}{l}\text { constructed } \\
1961\end{array}$ \\
\hline $93-0300-056$ & $\begin{array}{l}\text { Remove C3-S7 from Service/ } \\
\text { ECN } 143565\end{array}$ & III & $8 / 23 / 93$ & N/A & $\mathrm{N} / \mathrm{A}$ & $8 / 26 / 93$ & WHC & no known \\
\hline $93-0300-057$ & 3701-T Building Demolition & VI & $8 / 20 / 93$ & N/A & N/A & $8 / 20 / 93$ & WHC & $\begin{array}{l}\text { constructed } \\
1972\end{array}$ \\
\hline $93-0300-058$ & ER 4039, Chilled Water System & III & $8 / 23 / 93$ & N/A & N/A & $8 / 31 / 93$ & PNL & no known \\
\hline $93-0300-059$ & 331 Nitrogen Tank Project & III & $8 / 26 / 93$ & N/A & $\mathrm{N} / \mathrm{A}$ & $9 / 1 / 93$ & PNL & no known \\
\hline $93-0300-060$ & $\begin{array}{l}3768,3769,3770 \mathrm{Re}- \\
\text { Landscaping }\end{array}$ & III & $8 / 27 / 93$ & N/A & N/A & $9 / 1 / 93$ & WHC & no known \\
\hline $93-0300-061$ & $\begin{array}{l}\text { Wisconsin St. Entrance } \\
\text { Modifications }\end{array}$ & III & $8 / 27 / 93$ & N/A & N/A & $9 / 1 / 93$ & WHC & no known \\
\hline
\end{tabular}


Table A.1. (Contd)

\begin{tabular}{|c|c|c|c|c|c|c|c|c|}
\hline Case \# & Project Name & Class & $\begin{array}{c}\text { Date } \\
\text { Received }\end{array}$ & Survey & Monitoring & \begin{tabular}{c|} 
Date \\
Completed
\end{tabular} & $\begin{array}{c}\text { Requesting } \\
\text { Organization }\end{array}$ & $\begin{array}{c}\text { Cultural } \\
\text { Resources? }\end{array}$ \\
\hline $93-0300-062$ & $\begin{array}{l}300 \text { Area, TV Gate } \\
\text { Modifications }\end{array}$ & III & $8 / 27 / 93$ & N/A & N/A & $9 / 1 / 93$ & WHC & no known \\
\hline $93-0300-063$ & $\begin{array}{l}\text { Project L-186, Hanford Site } \\
\text { Entry Control Center }\end{array}$ & $\mathrm{V}$ & $8 / 27 / 93$ & Oct. 93 & N/A & FY 1994 & $\overline{\text { WHC }}$ & $\begin{array}{l}3 \text { sites-not } \\
\text { pot. eligible }\end{array}$ \\
\hline $93-0300-064$ & 3769 Install Concrete Sidewalk & III & $8 / 27 / 93$ & N/A & N/A & $9 / 3 / 93$ & WHC & no known \\
\hline $93-0300-065$ & $\begin{array}{l}\text { Re-Landscape the } \\
3790 \text { Building }\end{array}$ & I & $8 / 30 / 93$ & N/A & $\mathrm{N} / \mathrm{A}$ & $9 / 3 / 93$ & WHC & no known \\
\hline $93-0300-066$ & 300 Area Building Painting & VI & $9 / 2 / 93$ & $\mathrm{~N} / \mathrm{A}$ & $\mathrm{N} / \mathrm{A}$ & $9 / 3 / 93$ & $\overline{\text { WHC }}$ & $\begin{array}{l}\text { const. 1944, } \\
1950\end{array}$ \\
\hline $93-0300-067$ & Relocation of MO543 & III & $9 / 1 / 93$ & $\mathrm{~N} / \mathrm{A}$ & $\mathrm{N} / \mathrm{A}$ & $9 / 8 / 93$ & $\overline{\mathrm{KEH}}$ & no known \\
\hline $93-0300-068$ & 3708 Argon Tank & III & $9 / 8 / 93$ & $\mathrm{~N} / \mathrm{A}$ & N/A & $9 / 17 / 93$ & $\overline{\text { PNL }}$ & no known \\
\hline $93-0400-001$ & $\begin{array}{l}400 \text { Area Entrance } \\
\text { Modifications at East Parking } \\
\text { Lot }\end{array}$ & III & $5 / 3 / 93$ & N/A & N/A & $5 / 17 / 93$ & $\overline{\text { WHC }}$ & no known \\
\hline $93-0400-002$ & $\begin{array}{l}\text { Cold Testing of Tank Waste } \\
\text { Remediation Technologies }\end{array}$ & VI & $5 / 26 / 93$ & N/A & $\bar{N} / \mathrm{A}$ & $6 / 4 / 93$ & WHC & $\begin{array}{l}\text { constructed } \\
1984\end{array}$ \\
\hline $93-0400-003$ & $\begin{array}{l}\text { Bldg. 440, Haz. Waste Temp. } \\
\text { Storage Facility }\end{array}$ & III & $6 / 2 / 93$ & N/A & N/A & $6 / 4 / 93$ & WHC & no known \\
\hline $93-0400-004$ & 4802 Building Upgrades & VI & $6 / 4 / 93$ & N/A & $\mathrm{N} / \mathrm{A}$ & $6 / 11 / 93$ & $\overline{\text { WHC }}$ & $\begin{array}{l}\text { constructed } \\
1979\end{array}$ \\
\hline $93-0400-005$ & $\begin{array}{l}\text { Installation of Air Conditioning } \\
\text { in } 4802 \text { Building }\end{array}$ & $\overline{V I}$ & $6 / 4 / 93$ & N/A & $\mathrm{N} / \mathrm{A}$ & $6 / 7 / 93$ & WHC & $\begin{array}{l}\text { constructed } \\
1979\end{array}$ \\
\hline $93-0400-006$ & $\begin{array}{l}\text { F027--IEM Cell Enhancement/ } \\
\text { Interim Storage Area (FFTF) }\end{array}$ & III & $7 / 29 / 93$ & N/A & N/A & $8 / 2 / 93$ & WHC & no known \\
\hline
\end{tabular}


Table A.1. (Contd)

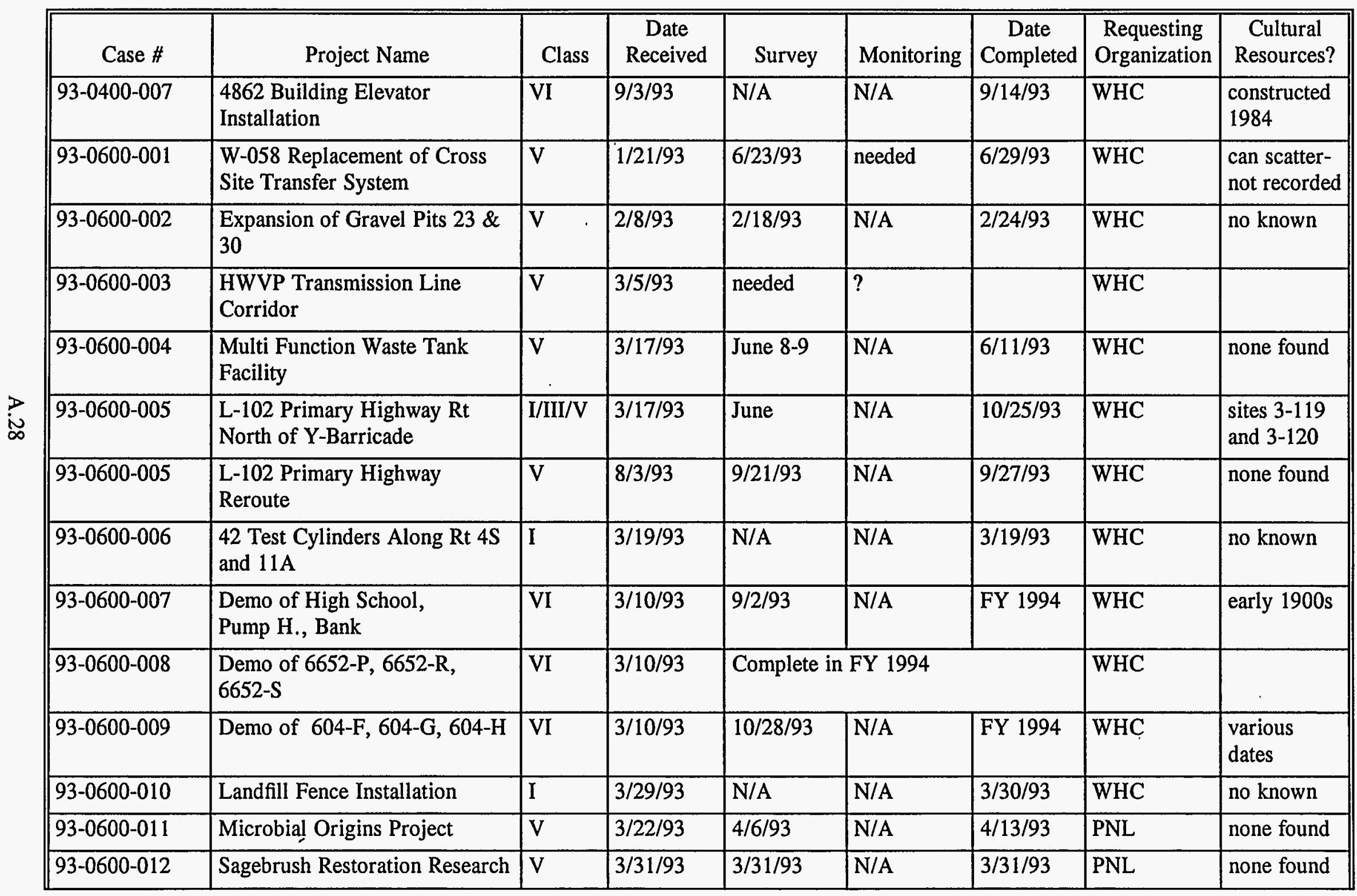


Table A.1. (Contd)

\begin{tabular}{|c|c|c|c|c|c|c|c|c|}
\hline Case \# & Project Name & Class & $\begin{array}{c}\text { Date } \\
\text { Received }\end{array}$ & Survey & Monitoring & \begin{tabular}{|c|} 
Date \\
Completed
\end{tabular} & \begin{tabular}{|l} 
Requesting \\
Organization
\end{tabular} & $\begin{array}{c}\text { Cultural } \\
\text { Resources? }\end{array}$ \\
\hline $93-0600-013$ & $\begin{array}{l}\text { Hanford IVDTS Job No. ISV } \\
\text { and 300N Area }\end{array}$ & III/V & $4 / 2 / 93$ & $4 / 12 / 93$ & N/A & $4 / 12 / 93$ & WAHCO & none found \\
\hline 93-0600-014 & SR 240 Access Road & $\mathrm{V}$ & $3 / 29 / 93$ & $4 / 13-14 / 93$ & $\mathrm{~N} / \mathrm{A}$ & $5 / 25 / 93$ & WHC & $\begin{array}{l}\text { HT-93-001, } \\
\text { HT-93-002 }\end{array}$ \\
\hline $93-0600-015$ & $\begin{array}{l}\text { W-058, Replacement of Cross } \\
\text { Site Transfer System--Soil } \\
\text { Sampling }\end{array}$ & IIII/V & $4 / 1 / 93$ & N/A & N/A & $8 / 13 / 93$ & WHC & no known \\
\hline $93-0600-016$ & $\begin{array}{l}\text { Hanford Well and Borehole } \\
\text { Survey }\end{array}$ & III/V & $4 / 2 / 93$ & $4 / 13 / 93$ & $\mathrm{~N} / \mathrm{A}$ & $4 / 15 / 93$ & J.E.Chance & none found \\
\hline $93-0600-017$ & $\begin{array}{l}\text { WPPSS WNP-2 Emergency } \\
\text { Evacuation System Siren }\end{array}$ & $\mathrm{V}$ & $4 / 17 / 93$ & $6 / 3 / 93$ & 9/7/93 & $6 / 4 / 93$ & DOE & none found \\
\hline $93-0600-018$ & ESCR Heterogeneity Research & V & $4 / 14 / 93$ & N/A & N/A & $5 / 20 / 93$ & PNL & no known \\
\hline $93-0600-019$ & $\begin{array}{l}\text { Hanford Patrol Power Line } \\
\text { Extension Range }\end{array}$ & III/V & $5 / 12 / 93$ & $5 / 13 / 93$ & $8 / 24 / 93$ & $8 / 25 / 93$ & WHC & none found \\
\hline $93-0600-020$ & W-105 Pipe Project-600 Area & I & $5 / 12 / 93$ & $\mathrm{~N} / \mathrm{A}$ & N/A & $5 / 13 / 93$ & WHC & no known \\
\hline $93-0600-021$ & IVDTS & III & $5 / 18 / 93$ & $5 / 26 / 93$ & N/A & $5 / 26 / 93$ & WHC & none found \\
\hline $93-0600-022$ & $\begin{array}{l}\text { Relocation of } 24 X 48 \text { Mobil } \\
\text { Unit to Patrol Training } \\
\text { Academy }\end{array}$ & III & $5 / 19 / 93$ & N/A & $\overline{N / A}$ & $5 / 20 / 93$ & WHC & no known \\
\hline $93-0600-023$ & $\begin{array}{l}\begin{array}{l}\text { City of Richland/Horn Rapids } \\
\text { Substation }\end{array} \\
\end{array}$ & III $/ \mathrm{V}$ & $6 / 2 / 93$ & $5 / 18 / 92$ & N/A & $6 / 10 / 93$ & W.HC & none found \\
\hline $93-0600-024$ & $\begin{array}{l}\text { McGee Ranch Characterization } \\
\text { Additional Boreholes }\end{array}$ & V & $\begin{array}{l}5 / 24 / 1993 \\
6 / 28 / 93\end{array}$ & done 1991 & N/A & $\begin{array}{l}5 / 27 / 93 \\
6 / 29 / 93\end{array}$ & WHC & nearby \\
\hline $93-0600-025$ & $\begin{array}{l}2 \text { Monitoring Wells--Solid } \\
\text { Waste Landfill }\end{array}$ & III & $5 / 28 / 93$ & $\begin{array}{l}3 / 28-4 / 3 \\
1989\end{array}$ & N/A & $6 / 1 / 93$ & WHC & none found \\
\hline
\end{tabular}


Table A.1. (Contd)

\begin{tabular}{|c|c|c|c|c|c|c|c|c|}
\hline Case \# & Project Name & Class & $\begin{array}{c}\text { Date } \\
\text { Received }\end{array}$ & Survey & Monitoring & \begin{tabular}{|c|} 
Date \\
Completed
\end{tabular} & $\begin{array}{c}\text { Requesting } \\
\text { Organization }\end{array}$ & $\begin{array}{c}\text { Cultural } \\
\text { Resources? }\end{array}$ \\
\hline $93-0600-026$ & $\begin{array}{l}\text { Electrical Mods for SCBA } \\
\text { Trailer }\end{array}$ & III & $6 / 14 / 93$ & N/A & N/A & $6 / 16 / 93$ & WHC & no known \\
\hline $93-0600-027$ & Demolition of Building & VI & $6 / 21 / 93$ & \multicolumn{3}{|c|}{ Complete in FY 1994} & WHC & \\
\hline $93-0600-028$ & W-152 & $\mathrm{V}$ & $6 / 24 / 93$ & July/Aug. & N/A & $8 / 16 / 93$ & WHC & no signif. \\
\hline $93-0600-029$ & $\begin{array}{l}\text { 618-10 Burial Ground } \\
\text { Excavation }\end{array}$ & & $6 / 25 / 93$ & N/A & N/A & $7 / 13 / 93$ & WHC & no known \\
\hline $93-0600-030$ & $\begin{array}{l}\text { 618-11 Burial Ground } \\
\text { Remediation }\end{array}$ & III & $6 / 25 / 93$ & N/A & N/A & $6 / 29 / 93$ & $\overline{\text { WHC }}$ & no known \\
\hline $93-0600-031$ & $\begin{array}{l}\text { Roof Repair, 621B, 661A, 662, } \\
\text { 662A, 309, 3707C, 3713, } \\
\text { 3717B }\end{array}$ & VI & $6 / 29 / 93$ & N/A & N/A & $7 / 8 / 93$ & WHC & $\begin{array}{l}\text { some bldgs } \\
\text { potent. } \\
\text { eligible }\end{array}$ \\
\hline $93-0600-032$ & $\begin{array}{l}\text { Sign Replacement at } \\
\text { Y-Barricade }\end{array}$ & $I$ & $7 / 19 / 93$ & N/A & N/A & $7 / 22 / 93$ & $\overline{\text { WHC }}$ & no known \\
\hline $93-0600-033$ & $\begin{array}{l}\text { Fence Installation at Hanford } \\
\text { Townsite School \& White } \\
\text { Bluffs Bank }\end{array}$ & III & $7 / 22 / 93$ & $\mathrm{~N} / \mathrm{A}$ & N/A & $7 / 23 / 93$ & WHC & no known \\
\hline $93-0600-034$ & $\begin{array}{l}\text { Install Backflow Preventer at } \\
609--100 \text { N Fire Station }\end{array}$ & III & $\begin{array}{l}7 / 21 / 93 \\
7 / 27 / 93\end{array}$ & $\begin{array}{l}\text { N/A } \\
\text { N/A }\end{array}$ & $\begin{array}{l}\text { N/A } \\
\text { N/A }\end{array}$ & $\begin{array}{l}7 / 26 / 93 \\
7 / 29 / 93\end{array}$ & WHC & $\begin{array}{l}\text { no known } \\
\text { no known }\end{array}$ \\
\hline $93-0600-035$ & $\begin{array}{l}480 \text { VAC Outdoor Power } \\
\text { Receptacles for Instrumentation } \\
\text { Trucks }\end{array}$ & $\mathrm{VI}$ & $8 / 10 / 93$ & N/A & N/A & $8 / 13 / 93$ & $\overline{\mathrm{PNL}}$ & $\begin{array}{l}\text { constructed } \\
1966\end{array}$ \\
\hline $93-0600-036$ & $\begin{array}{l}\text { Project W-164, Sample } \\
\text { Equipment Cleaning Facility }\end{array}$ & III & $8 / 11 / 93$ & $\begin{array}{l}4 / 26-27 / \\
1988\end{array}$ & N/A & $8 / 19 / 93$ & WHC & none found \\
\hline $93-0600-037$ & $\begin{array}{l}\text { Solid Waste Landfill--Soil Gas } \\
\text { Probes }\end{array}$ & III & $8 / 23 / 93$ & $3 / 28 / 89$ & N/A & $8 / 26 / 93$ & WHC & none found \\
\hline $93-0600-038$ & Rail Line for ERSDF & $\overline{\mathrm{V}}$ & $9 / 1 / 93$ & needed & & FY 1994 & WHC & \\
\hline
\end{tabular}


Table A.1. (Contd)

\begin{tabular}{|c|c|c|c|c|c|c|c|c|}
\hline Case \# & Project Name & Class & $\begin{array}{c}\text { Date } \\
\text { Received }\end{array}$ & Survey & Monitoring & $\begin{array}{c}\text { Date } \\
\text { Completed }\end{array}$ & \begin{tabular}{|l|} 
Requesting \\
Organization
\end{tabular} & $\begin{array}{c}\text { Cultural } \\
\text { Resources? }\end{array}$ \\
\hline $93-0600-039$ & $\begin{array}{l}\text { BPA Switching Station-- } \\
\text { Expansion }\end{array}$ & $\mathrm{I}$ & $9 / 2 / 93$ & N/A & N/A & $9 / 13 / 93$ & DOE & no known \\
\hline $93-0600-040$ & HAMMER Training Center & $\mathrm{V}$ & $9 / 1 / 93$ & needed & & FY 1994 & USACE & \\
\hline $93-0600-041$ & Fencing of Bruggeman Cottage & IV & $9 / 15 / 93$ & N/A & N/A & $9 / 22 / 93$ & WHC & $\begin{array}{l}\text { no adv. } \\
\text { effect }\end{array}$ \\
\hline $93-0600-042$ & $\begin{array}{l}\text { Survey of Selected Cleanup } \\
\text { Sites on ALE by USACE }\end{array}$ & III/V & $7 / 13 / 93$ & $\begin{array}{l}\text { July-Aug } \\
1993\end{array}$ & $\mathrm{~N} / \mathrm{A}$ & FY 1994 & USACE & 27 sites \\
\hline $93-1100-001$ & 1171 Herbicide Storage Bldg. & III & $5 / 19 / 93$ & N/A & N/A & $5 / 21 / 93$ & WHC & no known \\
\hline $93-1100-002$ & $\begin{array}{l}1100 \text { Area Site Location } \\
\text { Reviews }\end{array}$ & III & $9 / 3 / 93$ & $\mathrm{~N} / \mathrm{A}$ & N/A & $9 / 13 / 93$ & USACE & no known \\
\hline $93-3000-001$ & $\begin{array}{l}\text { K-005 } 3000 \text { Area North End } \\
\text { Utilities Upgrade }\end{array}$ & $\mathrm{I}$ & $4 / 29 / 93$ & $\mathrm{~N} / \mathrm{A}$ & $\mathrm{N} / \mathrm{A}$ & $5 / 6 / 93$ & KEH & no known \\
\hline $93-3000-002$ & $\begin{array}{l}\text { Modification of } 1256,1262, \\
1264, \& 1301 \text { Buildings }\end{array}$ & VI & $8 / 18 / 93$ & $\mathrm{~N} / \mathrm{A}$ & N/A & $8 / 24 / 93$ & KEH & $\begin{array}{l}\text { constructed } \\
1951,1980 \text {, } \\
1985\end{array}$ \\
\hline $93-0000-001$ & $\begin{array}{l}\text { Place Fiber Optic Cable from } \\
\text { Kennewick High to Richland }\end{array}$ & III & $5 / 6 / 93$ & $\mathrm{~N} / \mathrm{A}$ & N/A & $5 / 18 / 93$ & GTE & no known \\
\hline $93-0000-002$ & DH-5 Abandonment & III & $5 / 17 / 93$ & $5 / 25 / 93$ & $\mathrm{~N} / \mathrm{A}$ & $5 / 26 / 93$ & WHC & none found \\
\hline $93-0000-003$ & GTE Telephone Easement & III & $8 / 9 / 93$ & N/A & N/A & $8 / 17 / 93$ & DOE & no known \\
\hline $93-0000-004$ & TCI Cablevision Easement & $\mathrm{I}$ & $8 / 9 / 93$ & N/A & N/A & $8 / 16 / 93$ & DOE & no known \\
\hline $93-0000-005$ & $\begin{array}{l}\text { Yakima Training Center Bald } \\
\text { Eagle Perch Sighting }\end{array}$ & $\bar{V}$ & \multicolumn{4}{|c|}{$\begin{array}{l}\text { SURVEY CANCELLED - NOT IN } \\
\text { JURISDICTION }\end{array}$} & PNL & \\
\hline VC93-0100-01 & $116 \mathrm{~N}$ Hydrant $24 \mathrm{~N}$ & I & $2 / 16 / 93$ & $\mathrm{~N} / \mathrm{A}$ & N/A & $2 / 17 / 93$ & WHC & no known \\
\hline VC93-0100-02 & $\begin{array}{l}100 \text { Area Excavation } \\
\text { Treatability Test }\end{array}$ & I & $2 / 17 / 93$ & N/A & N/A & $2 / 17 / 93$ & WHC & no known \\
\hline
\end{tabular}


Table A.1. (Contd)

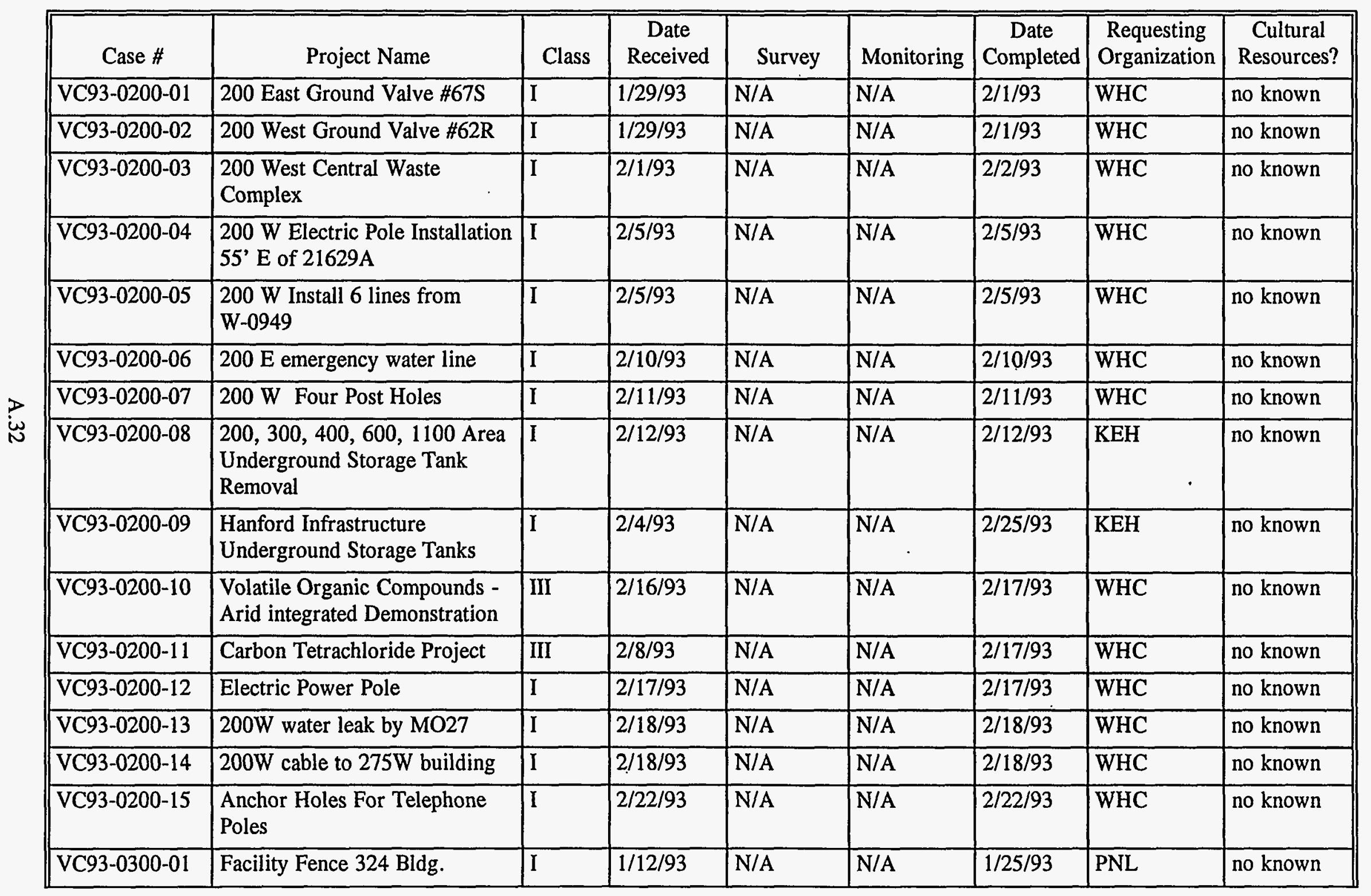


Table A.1. (Contd)

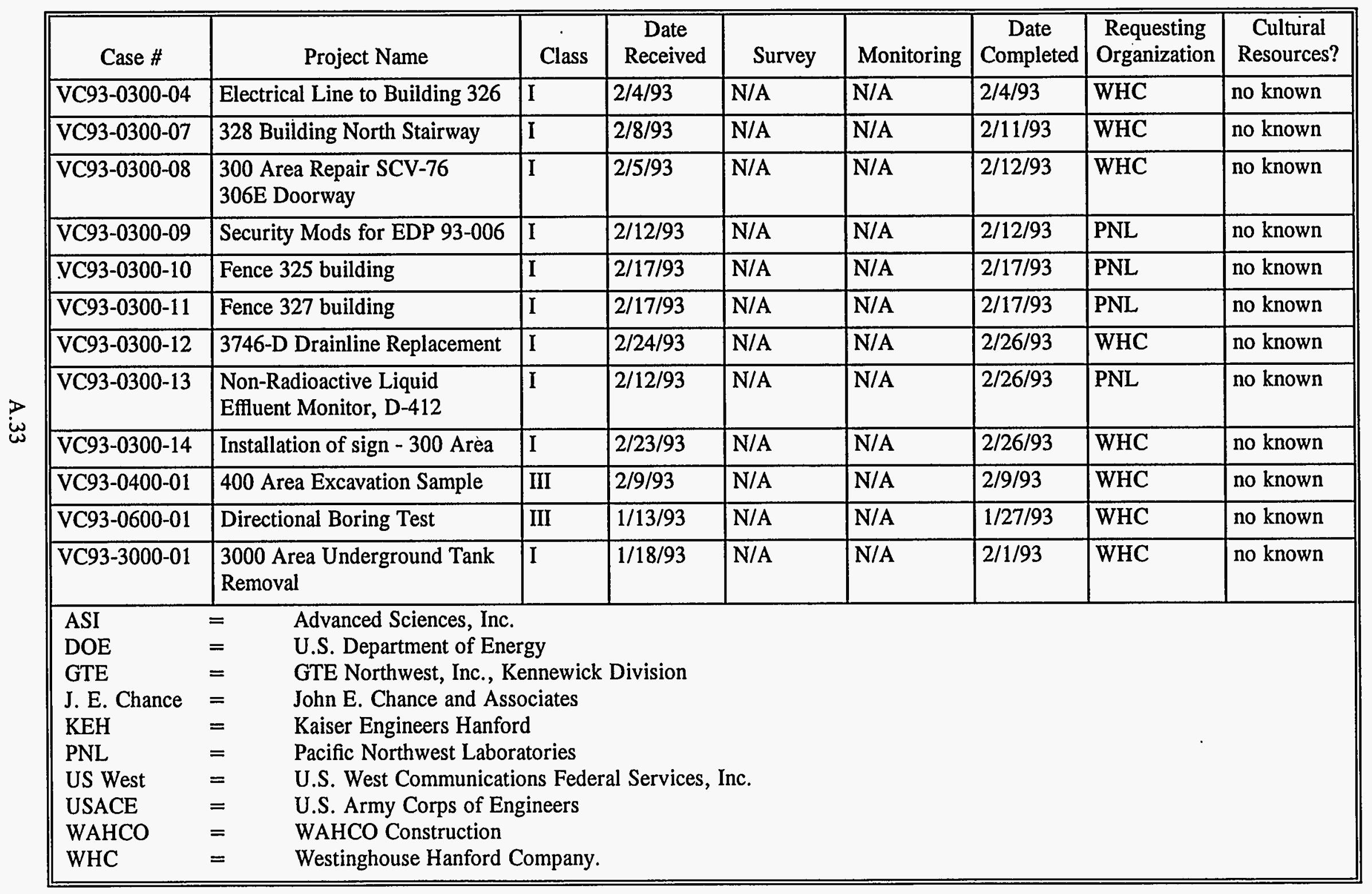


Appendix B

Surveys and Site Recordations

Performed in FY 1993 


\section{Appendix B}

\section{Surveys and Site Recordations Performed in FY 1993}

The surveys and site recordations conducted by the HCRL staff during FY 1993 are compiled in numerical order. For each case, descriptions are provided for the project, surveyed area, techniques used in the survey, and the survey findings. Project maps are included where appropriate.

Surveys and site recordations are performed in response to projects that will occur on undisturbed land where no previous surveys have been conducted. The HCRL staff completed 28 surveys/site recordations during FY 1993. 


\section{HCRC \#91-100 CERCLA}

\section{HR-3 Operable Units}

Project Description: The northern portion of the 100 HR-3 Operable Unit was surveyed during FY 1992 by walking in transects spaced $20 \mathrm{~m}$ apart. Since the FY 1992 fieldwork substantiated 1941 aerial photograph evidence of structure locations and complexes encountered during the intensive survey effort, these historic aerial photographs of the southern portion of the operable unit were studied to identify structures, features and other anomalies within the southern project boundary. Using this information, 52 locations were selected for field investigation during the FY 1993 field season.

Cultural Resources: Of the 52 locations chosen for investigation, 27 were recorded as historic sites; 18 of these were farmsteads with foundations, seven were possible homesteads or farmsteads with few if any features remaining, one was a large concrete block dump site, and one was a large circular depression. These sites represent the early Euro-American settlement period, the Depression era, and a more recent military presence on the Hanford Site. 
Table B.1. Sites Recorded in FY 1993 During the 100 HR-3 Operable Unit Project.

\begin{tabular}{|c|c|c|c|}
\hline HCRL Site No. & State No. & Site Type/description & Collected \\
\hline HT-93-027 & Not assigned & Dump & no \\
\hline HT-93-028 & Not assigned & Homestead & no \\
\hline HT-93-029 & Not assigned & Homestead & no \\
\hline HT-93-030 & Not assigned & Homestead & no \\
\hline HT-93-031 & Not assigned & Homestead & no \\
\hline HT-93-032 & Not assigned & Homestead & no \\
\hline HT-93-033 & Not assigned & Homestead & no \\
\hline HT-93-034 & Not assigned & Homestead & no \\
\hline HT-93-035 & Not assigned & Homestead & no \\
\hline HT-93-036 & Not assigned & Homestead & no \\
\hline HT-93-037 & Not assigned & Depressions & no \\
\hline HT-93-038 & Not assigned & Homestead & $\overline{\text { no }}$ \\
\hline HT-93-039 & Not assigned & Homestead & $\overline{\text { no }}$ \\
\hline HT-93-040 & Not assigned & Dump & no \\
\hline HT-93-041 & Not assigned & Dump & no \\
\hline HT-93-043 & Not assigned & Homestead & no \\
\hline HT-93-050 & Not assigned & Homestead & no \\
\hline HT-93-051 & Not assigned & Dump & no \\
\hline HT-93-052 & Not assigned & Concrete blocks & no \\
\hline HT-93-053 & Not assigned & Homestead & no \\
\hline HT-93-054 & Not assigned & Dump & no \\
\hline HT-93-055 & Not assigned & Dump & no \\
\hline HT-93-056 & Not assigned & Homestead & no \\
\hline HT-93-057 & Not assigned & Homestead & no \\
\hline HT-93-058 & Not assigned & Orchard & no \\
\hline HT-93-059 & Not assigned & Dump & no \\
\hline HT-93-060 & Not assigned & Homestead & no \\
\hline
\end{tabular}




\section{HCRC 91-300-024}

\section{Additional EMSL Support Facilities and Utility Lines}

Project Description: In the summer of 1993, additional proposed actions to support the Environmental and Molecular Sciences Laboratory (EMSL) were identified. These actions included a permanent power line, two temporary laydown yards and utilities including lines for natural gas, irrigation, sanitary water, and electrical power (Figure B.1). Since sections of these proposed actions are to occur on previously unsurveyed ground, additional survey was necessary. HCRL staff surveyed approximately $0.1 \mathrm{~km}^{2}$ on August 17,1993 . The area was covered by pedestrian transects spaced $20 \mathrm{~m}$ apart.

Cultural Resources: One historic site, HT-93-085, a dense concentration of cans, bottle glass, and other domestic items was recorded. A second historic site, HT-89-016, is located in the vicinity of the proposed electrical line north of Horn Rapids road. Neither site has been evaluated for eligibility for nomination to the National Register of Historic Places (NRHP). Both sites are far enough from the proposed actions that they can be avoided during construction. 


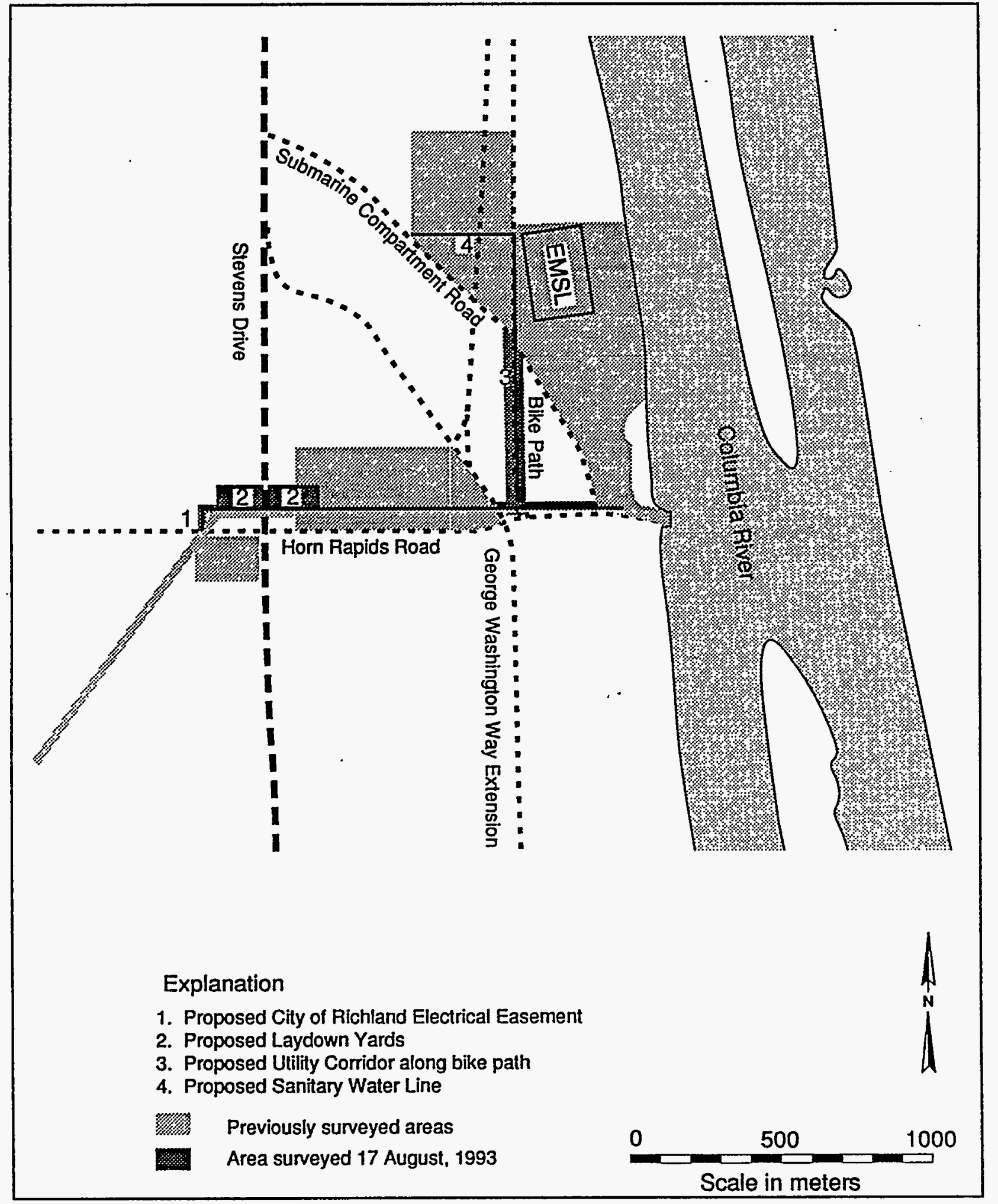

Figure B.1. The EMSL Project, HCRC \#91-300-024.

B.5 
HCRC \#92-600-028

\section{North Slope Waste Sites}

Project Description: The North Slope Waste Sites project will clean up 39 waste sites located on the North Slope of the Hanford Site (Figure B.2). Between September 1992 and July 1993, HCRL staff, assisted by NORCUS students, documented 29 of the 39 waste sites as cultural resources. Ten sites were not considered to be cultural resources sites.

Cultural Resources: Of the 29 documented sites, the eight recorded in FY 1992 represent early Euro-American ranching and settlement activities while the remaining 21 which were recorded in 1993 are military installations constructed during the Cold War era. None of the military sites is eligible for the NRHP. Of the eight historic sites recorded in FY 1992, five cisterns have been found to be potentially eligible for the NRHP within the context of a thematic district nomination. These cisterns will be backfilled during the clean-up process, which will stabilize the cistern walls. Therefore, it has been found that the project will have no effect on any characteristics that would make these sites eligible for listing on the NRHP. 
Table B.2. Sites Recorded in FY 1993 During the North Slope Waste Sites Project.

\begin{tabular}{|c|l|l|c||}
\hline HCRL Site No. & \multicolumn{1}{|c|}{ State No. } & \multicolumn{1}{|c|}{ Site Type/description } & Collected \\
\hline HT-93-006 & Not assigned & anti-aircraft site & no \\
\hline HT-93-007 & Not assigned & anti-aircraft site & no \\
\hline HT-93-008 & Not assigned & anti-aircraft site & no \\
\hline HT-93-009 & Not assigned & anti-aircraft site & no \\
\hline HT-93-010 & Not assigned & military & no \\
\hline HT-93-011 & Not assigned & anti-aircraft gun site & no \\
\hline HT-93-012 & Not assigned & anti-aircraft artillery site & no \\
\hline HT-93-013 & Not assigned & Nike missile control center & no \\
\hline HT-93-014 & Not assigned & Nike missile radar site & no \\
\hline HT-93-015 & Not assigned & Nike missile launch pad & no \\
\hline HT-93-016 & Not assigned & Nike missile control center-Battery A & no \\
\hline HT-93-017 & Not assigned & Nike missile base & no \\
\hline HT-93-018 & Not assigned & Nike missile launch site & no \\
\hline HT-93-019 & Not assigned & military debris scatter & no \\
\hline HT-93-020 & Not assigned & Nike missile control center- Battery B & no \\
\hline HT-93-021 & Not assigned & military debris site & no \\
\hline HT-93-022 & Not assigned & military radar site & no \\
\hline HT-93-023 & Not assigned & military debris site & no \\
\hline HT-93-024 & Not assigned & military observation point & no \\
\hline HT-93-025 & Not assigned & military ammunition storage & no \\
\hline HT-93-026 & Not assigned & military debris site & \\
\hline
\end{tabular}




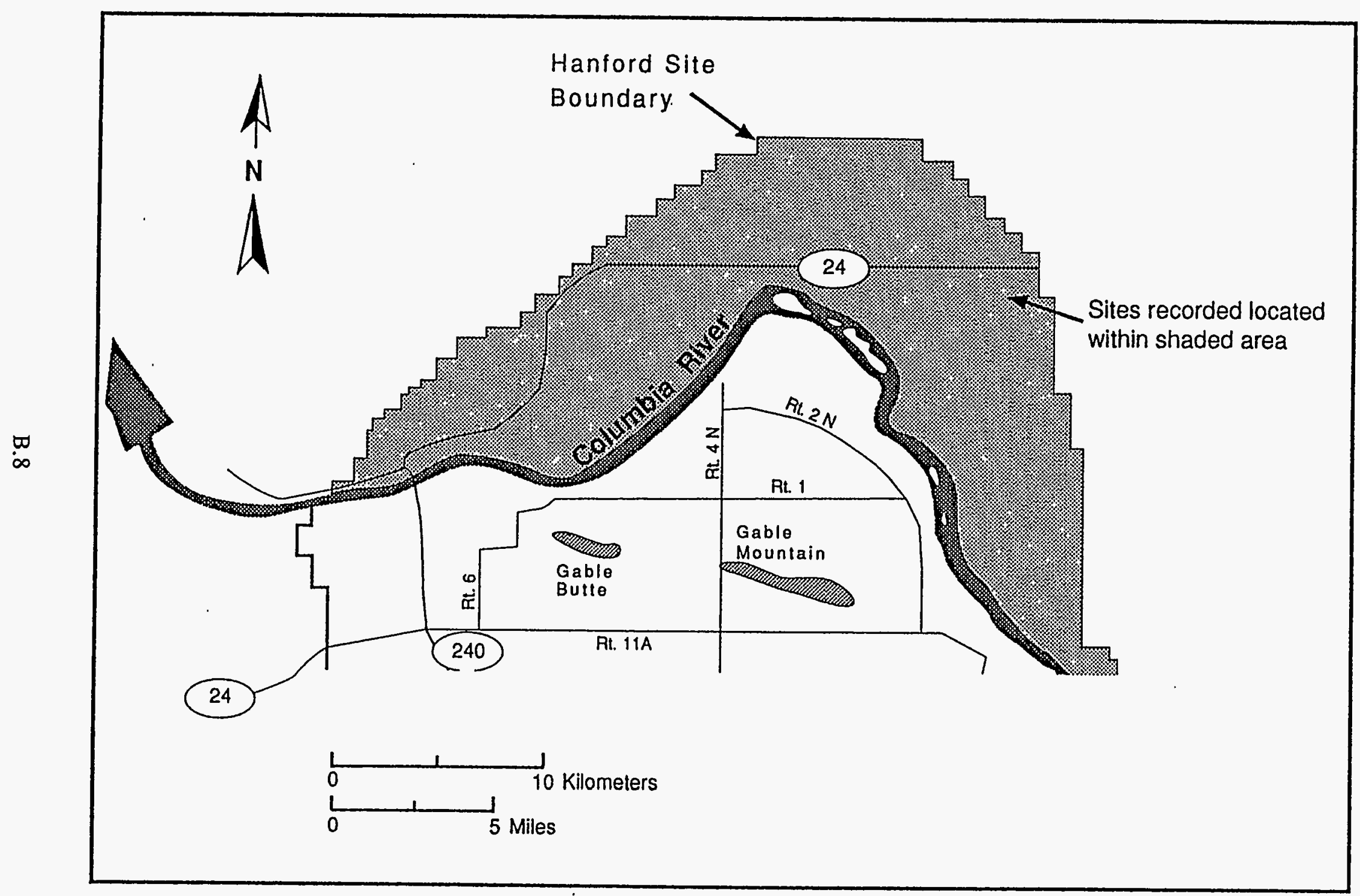

Figure B.2. Proposed Cleanup Locations on the North Slope, HCRC \#92-600-028 


\section{The Integrated Voice/Data Telecommunications System (IVDTS)}

Project Description: This project, which originated in FY 1992, entails installing a new communication system across the Hanford Site (see Figure B.3). Work activities will include installing cable with a cable plow and installing access holes when necessary to maintain the cable route. Excavation depth will range from $61 \mathrm{~cm}$ to $107 \mathrm{~cm}$ for the cable installation and up to a maximum of $3.3 \mathrm{~m}$ for the access holes. The project will be conducted in five phases.

HCRL staff conducted pedestrian surveys for much of the proposed route during FY 1992; however, surveys had not been completed for portions of Phases III through V at that time. These portions were surveyed from July 14 through July 23, 1993 by HCRL staff, using transects spaced $20 \mathrm{~m}$ apart. A total of $1.29 \mathrm{~km}^{2}$ was covered during the 1993 survey.

Cultural Resources: Site \#3-121 (HT-93-005) was recorded during the FY 1993 survey. The site is an irrigation valve system with a dry reservoir located directly to the north. Another site, \#3-122 (HT-92-022), was found during the FY 1992 survey and was recorded fully during the FY 1993 survey. This site includes a historic dump overlaying the apparent remains of Native American storage pits. Both sites are unevaluated as to NRHP eligibility, and will be avoided by all IVDTS construction. 


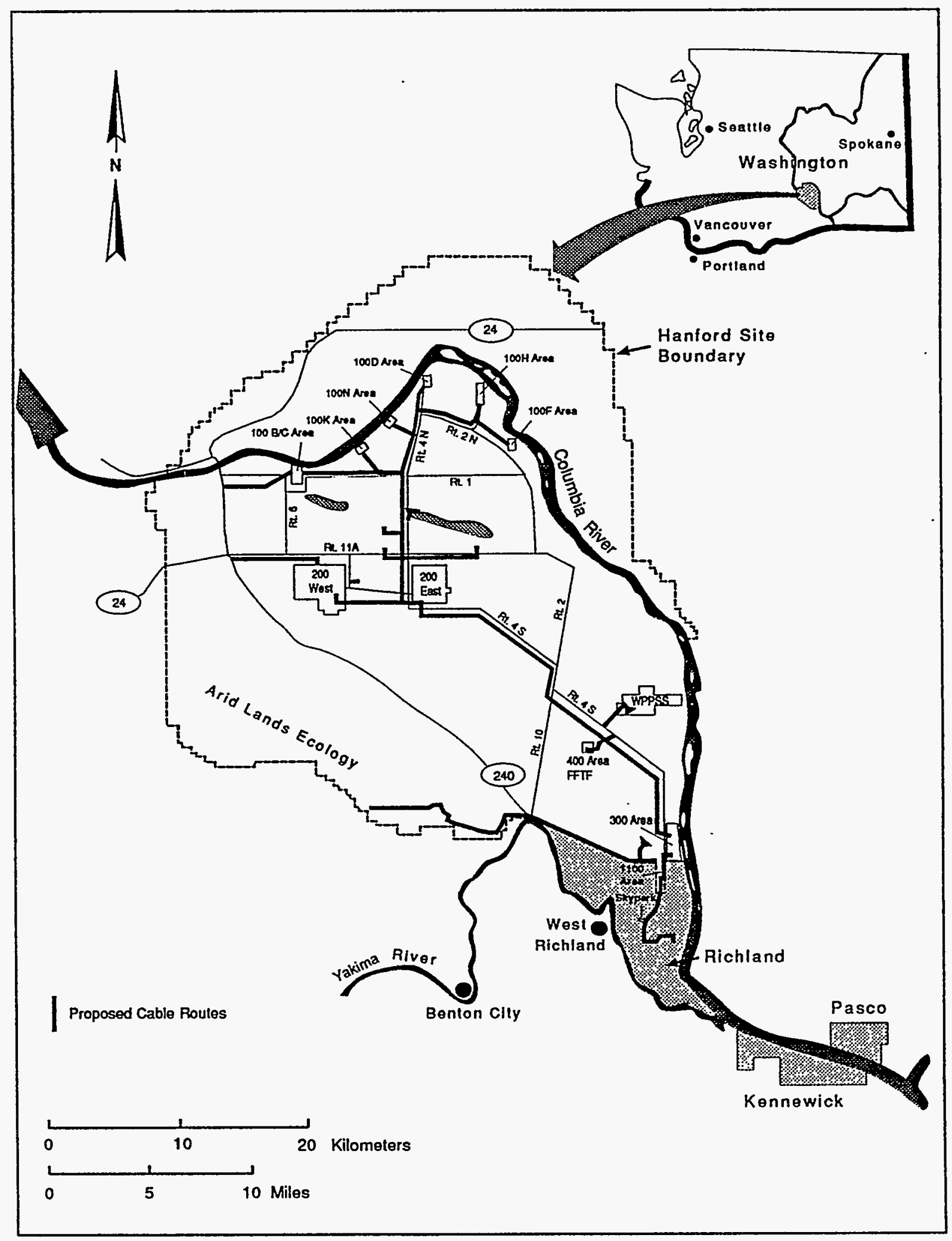

Figure B.3. Integrated Voice/Data Telecommunications System Project, HCRC \#92-600-029/92-600-030

B. 10 


\section{HCRC \#92-600-041}

The Fire Pump Modifications at Building 6652-PH

Project Description: The Fire Pump Modifications at Building 6652-PH project entails installing a new 3-inch ABS pipe from the 6652-PH Building to a new dry well located approximately 75 feet northeast of the facility. Project dimensions will be approximately 3 feet wide by 2 feet deep for the ABS pipe and 15 feet wide by 8 feet deep for the dry well construction. An examination of recent aerial photographs of the project area showed that the area had been somewhat disturbed. Due to the possibility of historic remnants, an area covering $1 \mathrm{~m}^{2}$ was surveyed on October 30, 1992.

Cultural Resources: No cultural materials were identified during the survey. Because the possibility of subsurface historic materials exists, monitoring of the project is required and will be completed at the time of construction. 


\section{HCRC \#93-100-005}

\section{Monitoring Well 199-N-N81}

Project Description: This project entails installing Monitoring Well 199-N-N81 east of the $\mathrm{N}$ Reactor. Because the literature and records review showed the area to be relatively undisturbed, it was surveyed by HCRL staff on February 4, 1993. The area surveyed covered approximately $0.0009 \mathrm{~km}^{2}$.

Cultural Resources: No cultural materials were located during the survey. 


\section{HCRC \#93-100-017}

\section{The Grout Treatment Facility Monitoring Wells}

Project Description: The Grout Treatment Facility Monitoring Wells project entails installing three monitoring wells near the Grout Treatment Facility, located east of the 200 East Area. Our literature and records review revealed that the area for Well \#3 had been surveyed during the survey that HCRL conducted for the Grout Treatment Facility. The review also showed that Wells \#1 and \#2 were located in previously undisturbed and unsurveyed areas. HCRL staff surveyed these two areas on February 4, 1993, covering a total of approximately $0.0018 . \mathrm{km}^{2}$.

Cultural Resources: No archaeological or cultural materials were identified on this survey or the previous survey which encompassed Well \#3. 
HCRC \#93-100-029

\section{The Columbia River Emergency Warning Siren System}

Project Description: The Columbia River Emergency Warning Siren System project (Figure B.4) will place five emergency sirens, each consisting of a tower measuring approximately $2 \mathrm{ft}$ by $2 \mathrm{ft}$, for a river alert warning system. The system is planned to cover the river from 1.5 miles west of the $100 \mathrm{~B} / \mathrm{C}$ Area downstream to the vicinity of the White Bluffs Ferry Landing. Since the literature and records review revealed that the sirens would be located in largely undisturbed areas where no surveys had been conducted previously, HCRL staff surveyed the five locations on May 10, 1993. The survey covered approximately $10 \mathrm{~m}^{2}$.

Cultural Resources: Two cans were noted but not recorded. No other cultural materials were found during the survey. 


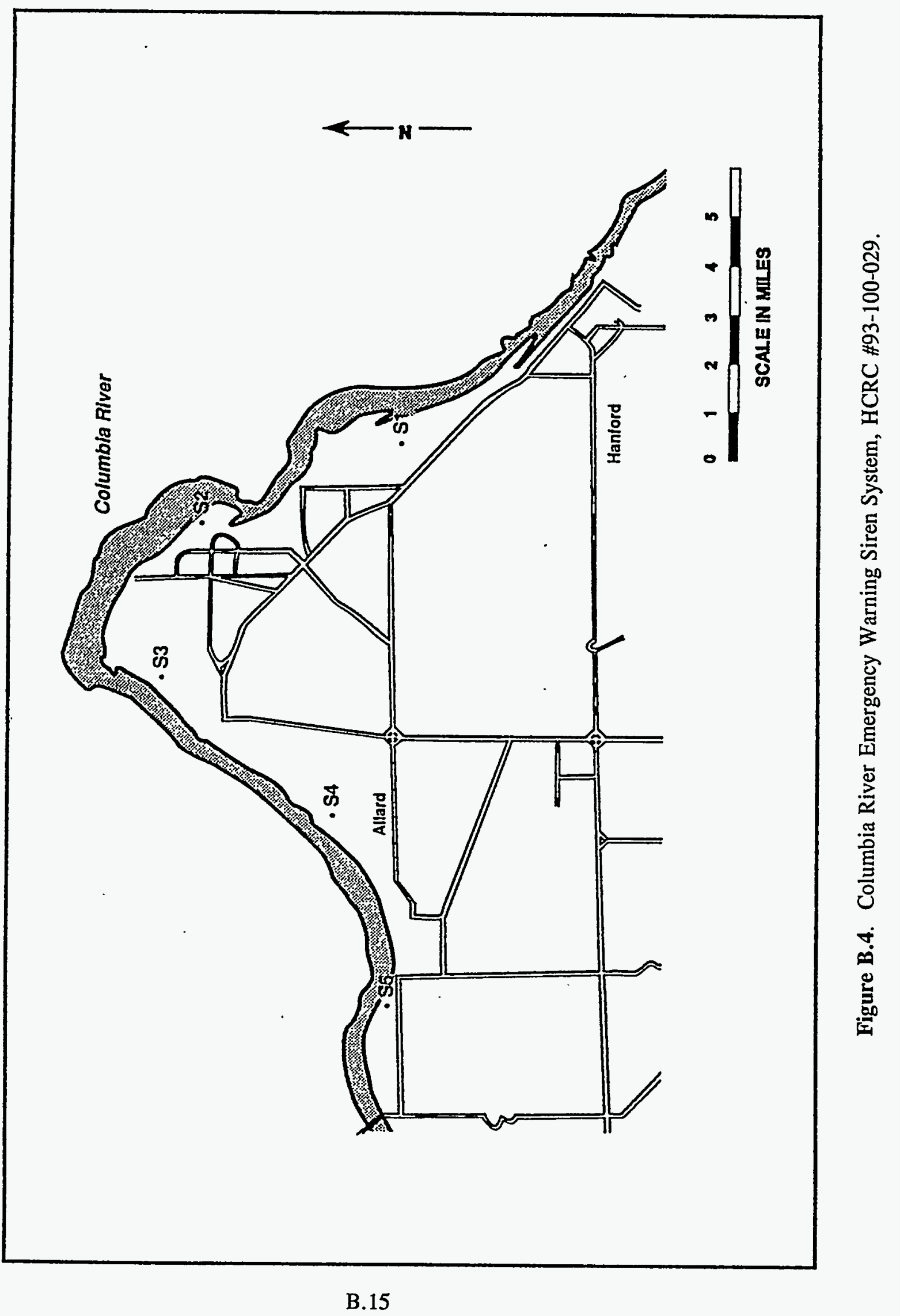


HCRC \#93-200-001

\section{Environmental Restoration Disposal Facility}

Project Description: The ERDF will provide the disposal site for the waste exhumed during the Hanford Site CERCLA and RCRA cleanup actions. Excavations at the site will be extensive and may be up to $12 \mathrm{~m}$ deep. The exact site boundaries have not yet been set, however, the proposed site area measures about $10.6 \mathrm{~km}^{2}$ (see Figure B.5). Most of the proposed project area had not been previously surveyed. HCRL staff surveyed approximately $11.0 \mathrm{~km}^{2}$ between July 21 and September 10, 1993. The area was covered by pedestrian transects spaced $20 \mathrm{~m}$ apart. Since the survey was completed, the site boundary has moved about $0.5 \mathrm{~km}$ to the east.

Cultural Resources: A previous survey in the proposed project area identified one prehistoric isolated artifact (HI-89-016), a cobble tool. Nine isolated artifacts, three prehistoric and six historic, and five sites, one paleontologic, one prehistoric, and three historic, were recorded in the area surveyed in the summer of 1993. Table B.3 and Table B.4 summarize the isolated artifacts and sites recorded.

Sites HP-93-001, HT-93-080, and HT-93-081 do not meet the criteria for listing on the National Register. The research potential of these sites and of all but one of the isolates has been exhausted through recordation and collection. Sites HT-93-083 and HT-93-084 by themselves do not retain nationally significant information. However, viewed in the broader historic context of Euro-American ranching in southeastern Washington, the sites represent part of the greater archaeological record, and may be considered regionally or locally significant viewed in this context. The project will have no effect on sites HT-93-083 and HT-93-084, given the most recent project area boundaries. 


\section{$L I^{\circ} \mathbf{g}$}

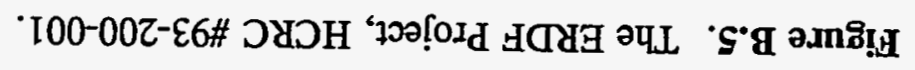

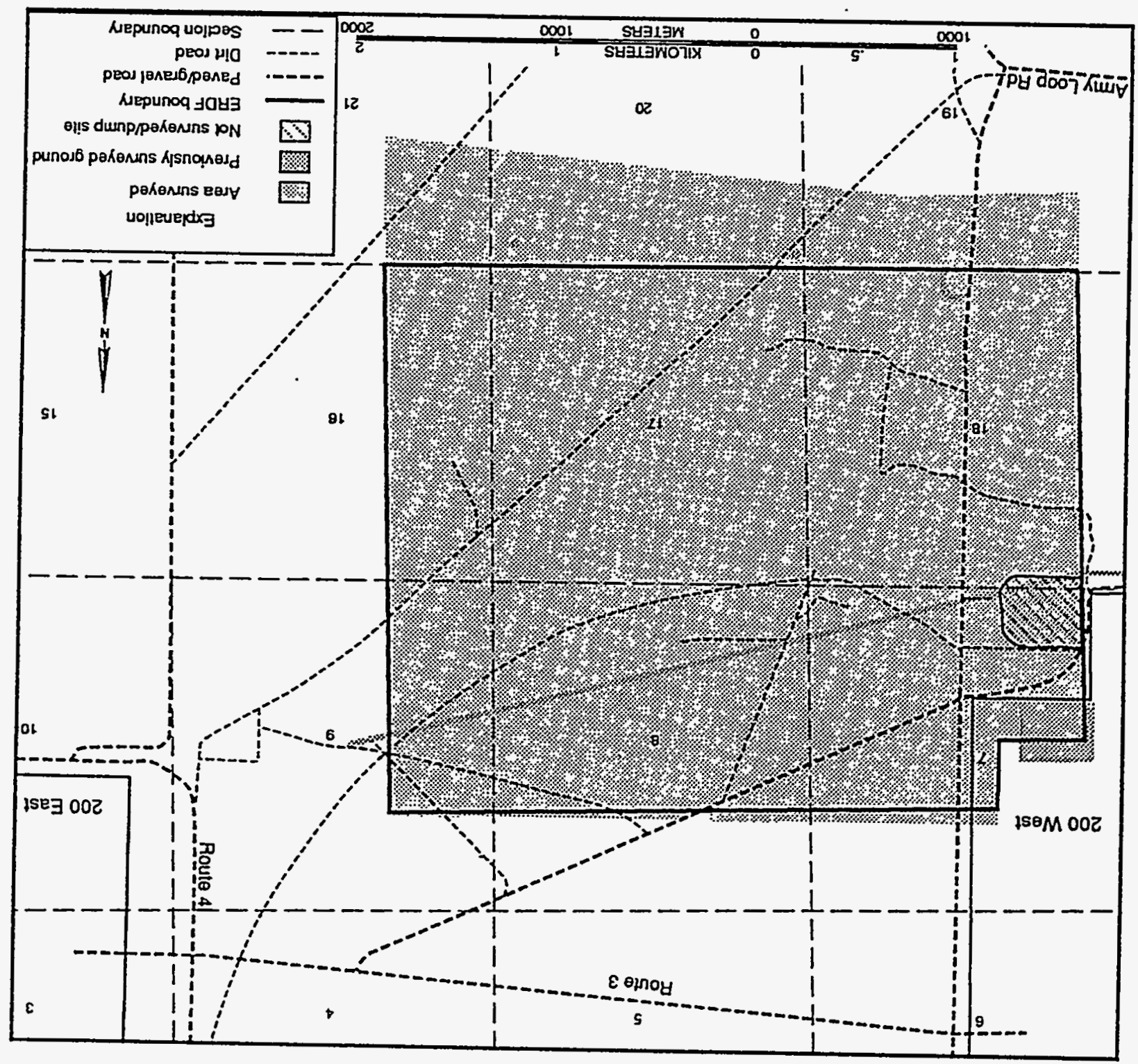


Table B.3. Isolated Artifacts Recorded During the ERDF Survey.

\begin{tabular}{||l|l|c||}
\hline \hline HCRL Isolate No. & \multicolumn{1}{|c|}{ Description } & Collected \\
\hline HI-93-001 & rod & yes \\
\hline HI-93-002 & two flakes & yes \\
\hline HI-93-004 & bóttle & yes \\
\hline HI-93-005 & can & yes \\
\hline HI-93-006 & flake & yes \\
\hline HI-93-007 & can & yes \\
\hline HI-93-009 & can & yes \\
\hline HI-93-010 & flake & yes \\
\hline HI-93-012 & rod & yes \\
\hline
\end{tabular}

Table B.4. Sites Recorded During the ERDF Survey.

\begin{tabular}{||l|l|l|c||}
\hline \hline HCRL Site No. & \multicolumn{1}{|c|}{ State No. } & \multicolumn{1}{|c|}{ Site Type/description } & Collected \\
\hline HP-93-001 & Not assigned & tooth enamel & yes \\
\hline HT-93-080 & Not assigned & two flakes, tooth enamel, historic debris & yes \\
\hline HT-93-081 & Not assigned & jar fragments & no \\
\hline HT-93-083 & Not assigned & wood frame structure & no \\
\hline HT-93-084 & Not assigned & stove/cans & no \\
\hline
\end{tabular}

B. 18 
HCRC \#93-200-004

\section{0-BP-1, Hanford Prototype Barrier}

Project Description: Project 200-BP-1, Hanford Prototype Barrier, entails removing basalt from an existing quarry site immediately south of the Vernita Bridge, just off of Highway 240. The quarry will be extended 50 to 100 feet to the south. The records and literature review showed that several archaeological sites and isolates were found within $1 \mathrm{~km}$ east of the project area during surveys conducted in 1990 and 1991, but that the area within the project boundaries had never been surveyed. On April 2, 1993, HCRL staff conducted a survey using transects spaced at $20 \mathrm{~m}$ intervals to cover $0.02 \mathrm{~km}^{2}$.

Cultural Resources: Several small, modern hunting blinds and plywood boxes were noted but not recorded. No other cultural materials were found during the survey. 


\section{HCRC \#93-200-005}

\section{Leaking Faucet at 2704-S}

Project Description: The Leaking Faucet at 2704-S project entails hand digging a 5-ft by 5-ft by 4 -ft deep hole to repair a leaking faucet on the north side of 2407-S. An area totaling approximately $2 \mathrm{~m}^{2}$ was surveyed on March 12, 1993.

Cultural Resources: No cultural resources were found during the survey. 


\section{Waste Sampling and Characterization Facility - Water Line}

Project Description: The water line installation at the Waste Sampling and Characterization Facility (Figure B.6) requires, in addition to the installation itself, a subsurface inspection of the connection between the new water line and existing mainlines. One trench will be constructed to complete each portion of the project. The inspection trench and part of the new line will be located within the 200 West Area, with a portion of the new line extending into the 600 Area. The segments within the 200 West Area were previously disturbed and did not require a survey, but the portion in the 600 Area was relatively undisturbed and did require a survey. HCRL staff conducted a pedestrian survey of this portion on May 18, 1993 by walking 2 transects spaced at $20 \mathrm{~m}$ intervals to cover approximately $0.06 \mathrm{~km}^{2}$.

Cultural Resources: No cultural materials were found during the survey. 


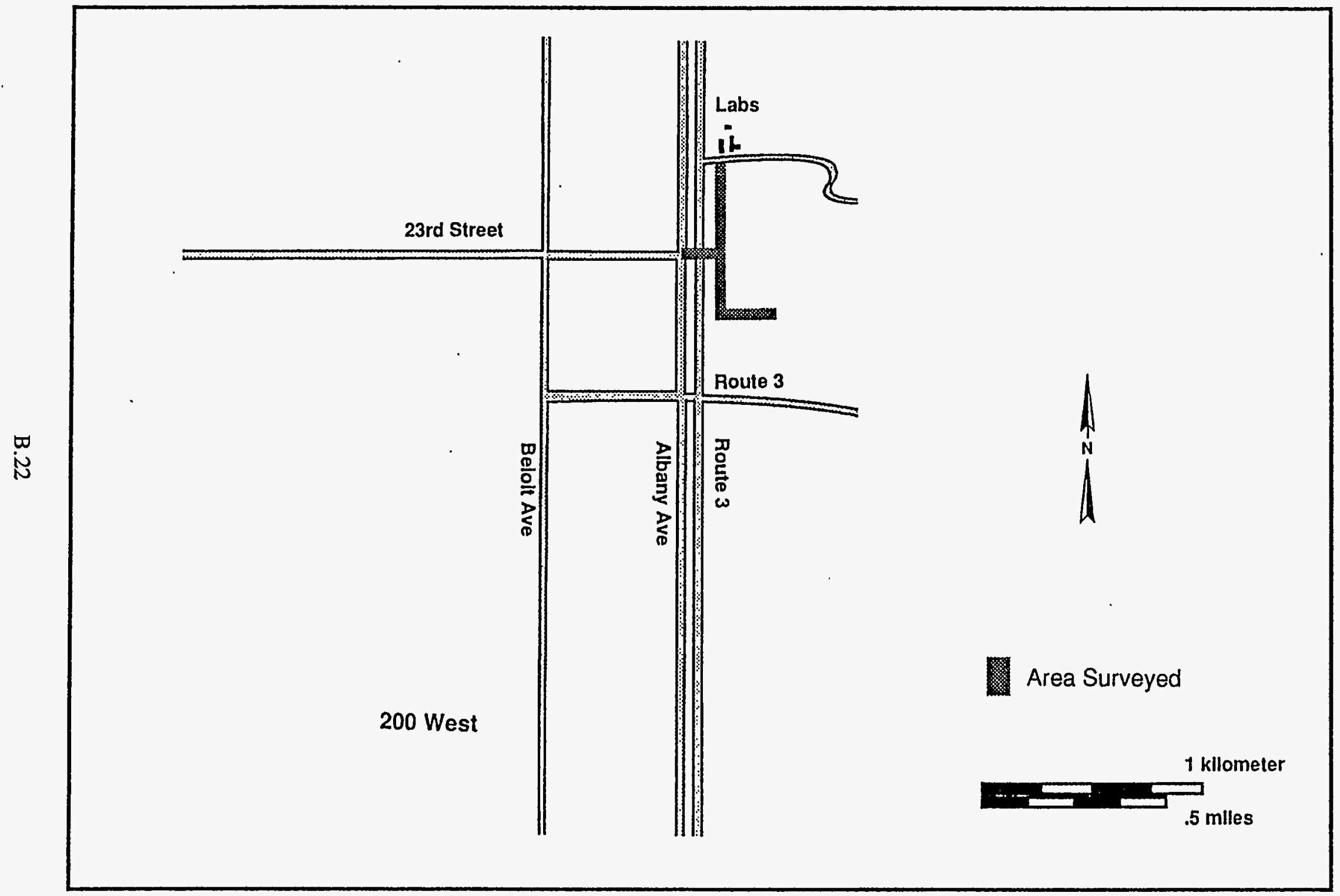

Figure B.6. Waste Sampling and Characterization Facility, HCRC \#93-200-027 
W-058, The Replacement of Cross Site Transfer System Project

Project Description: Project W-058, the Replacement of the Cross Site Transfer System (Figure B.7), entails installing a new transfer pipeline system which will transfer waste from storage facilities in the 200 West Area to the 200 East Area for treatment and disposal. The records and literature review showed that the project area was located in mainly undisturbed ground, with a large portion surveyed previously for HCRC \#90-600-023. A small portion, however, needed to be surveyed. On June 23, 1993, HCRL staff conducted a survey consisting of three transects spaced at $20 \mathrm{~m}$ intervals to cover the remaining project area.

Cultural Resources: No archaeological materials were found during the 1990 survey. One small can scatter and numerous scatters containing recent cans were noted but not recorded. No other cultural resources were found. 


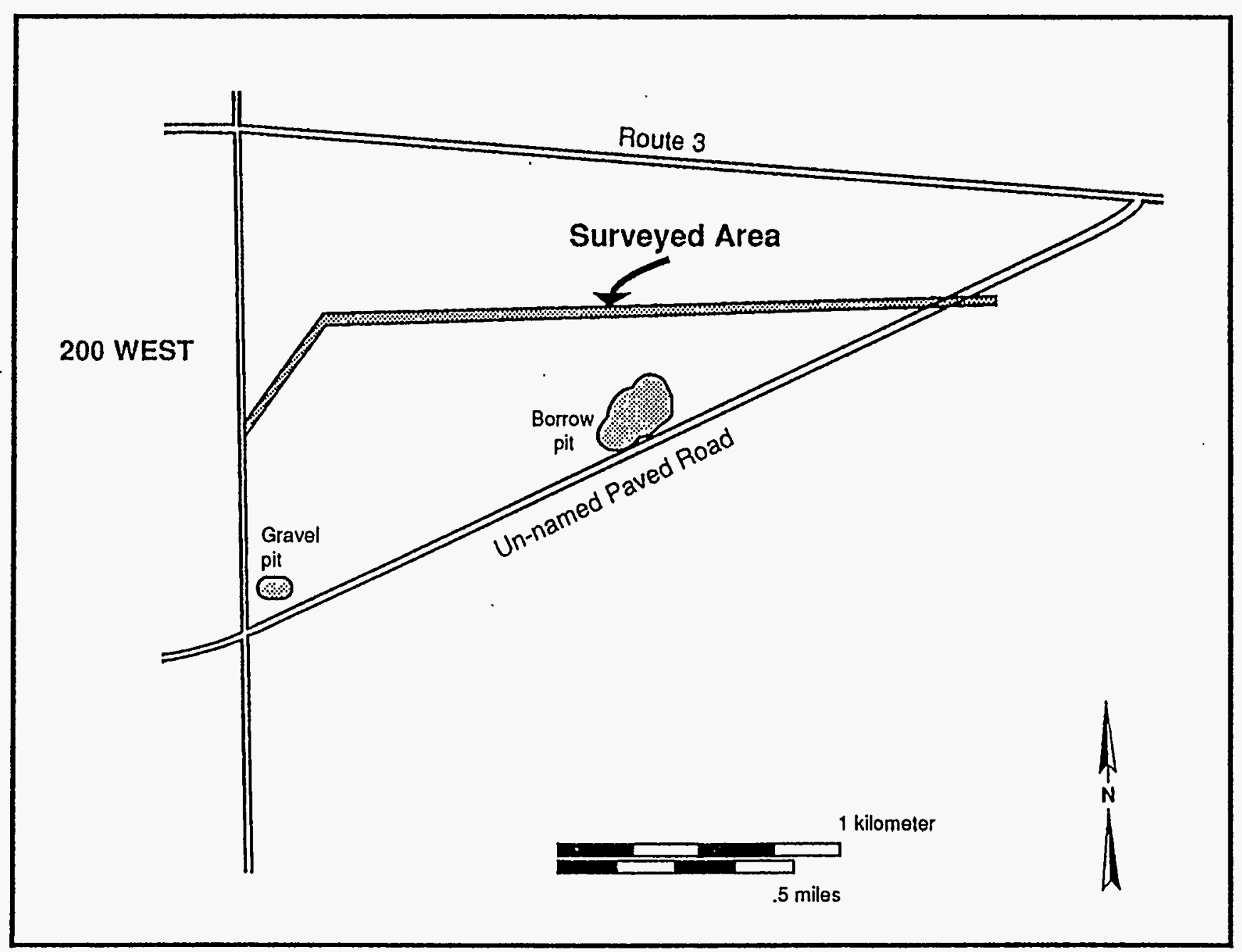

Figure B.7. W-058, Replacement of Cross Site Transfer System, HCRC \#93-600-001 


\section{The Expansion of Gravel Pits 23 and 30}

Project Description: The Expansion of Gravel Pits 23 and 30 project involves expanding Pits 23 and 30 for the suitability for concrete aggregate (Figure B.8). Intrusive work activities include expanding Pit 23 to include 11.1 acres to the east of it and Pit 30 to include 26.4 acres to the northwest of it. The records and literature review showed that 7.4 acres of the expansion area for Pit 23 had been disturbed by past mining activity, but that the remaining areas were relatively undisturbed. On February 18, 1993, HCRL staff surveyed the undisturbed portions of the expansion areas, covering the total 30.1 acres $\left(0.12 \mathrm{~km}^{2}\right)$. Transects spaced at $20 \mathrm{~m}$ intervals were used.

Cultural Resources: No archaeological materials were found during the survey. 

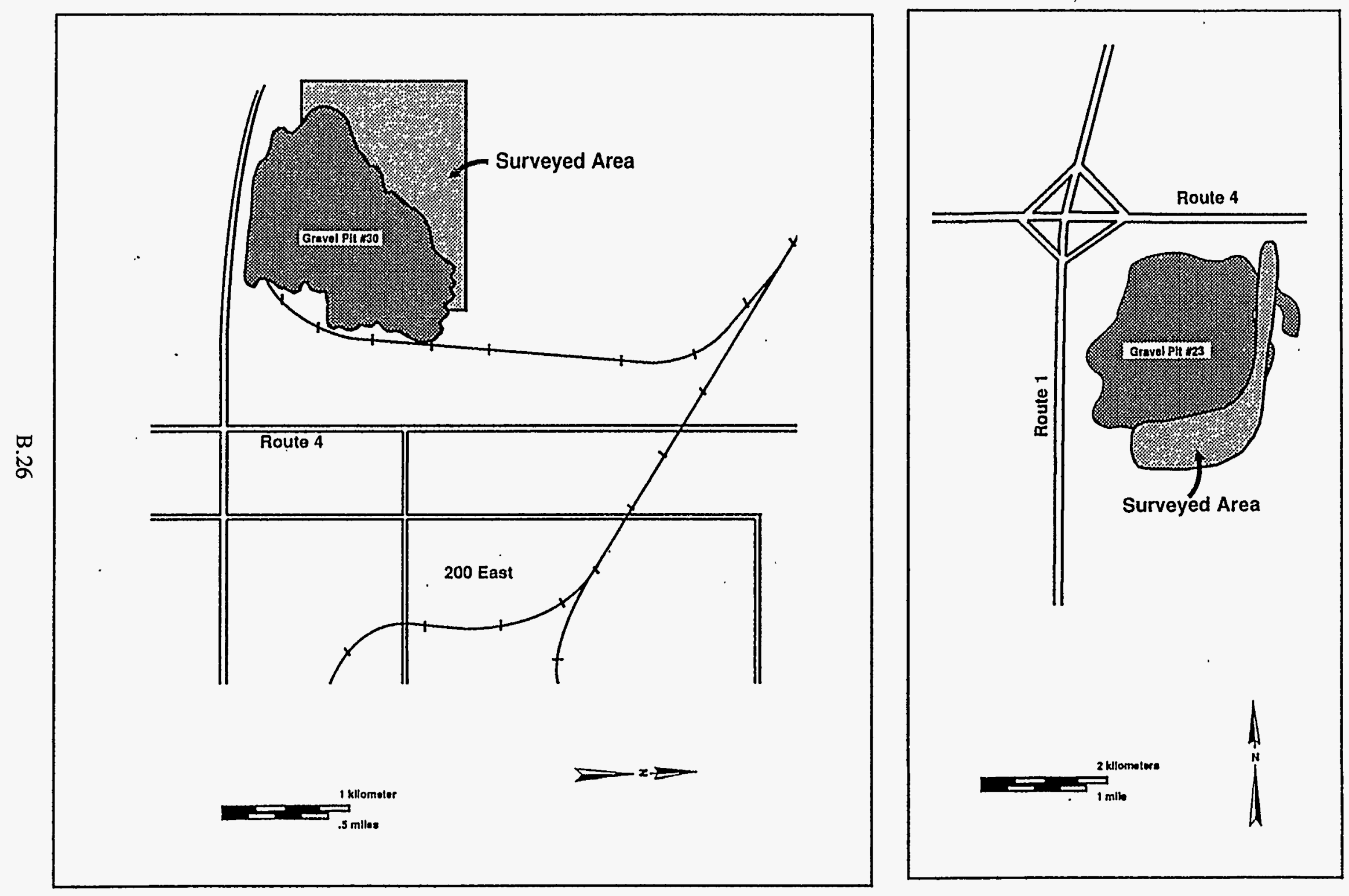

Figure B.8. Surveyed Areas at Gravel Pit Expansions, HCRC \#93-600-002 


\section{HCRC \#93-600-004}

\section{The Multi-Function Waste Tank Facility}

Project Description: The Multi-Function Waste Tank Facility (MFWTF) will provide two new waste storage tank facilities (Figure B.9). One area is located just west of 200 East, northwest of the intersection of Routes 3 and $4 \mathrm{~S}$, where four underground storage tanks and related support facilities will be constructed. The area originally included a section that had been surveyed previously (see HCRC \#91-600-006) and a smaller area that needed to be surveyed. However, the project area was changed to include only the area that had been previously surveyed, and therefore no new survey was conducted in this area. No archaeological resources were found during the 1991 survey.

The second project location will be inside 200 West, where a tank farm consisting of two underground waste storage tanks and associated support facilities and access roads will be constructed. An area approximately $280 \mathrm{~m} \mathrm{X} 400 \mathrm{~m}$ will be utilized, with an excavation depth of $18.3 \mathrm{~m}$. The area is mostly undisturbed and none of it had been surveyed previously. On June 8-9, 1993, the entire project area was surveyed by pedestrian transects spaced $20 \mathrm{~m}$ apart (see Figure B.9).

Cultural Resources: Several small concentrations of small mammal bones and a scatter of construction debris were noted but not recorded. No other archaeological materials were found. 


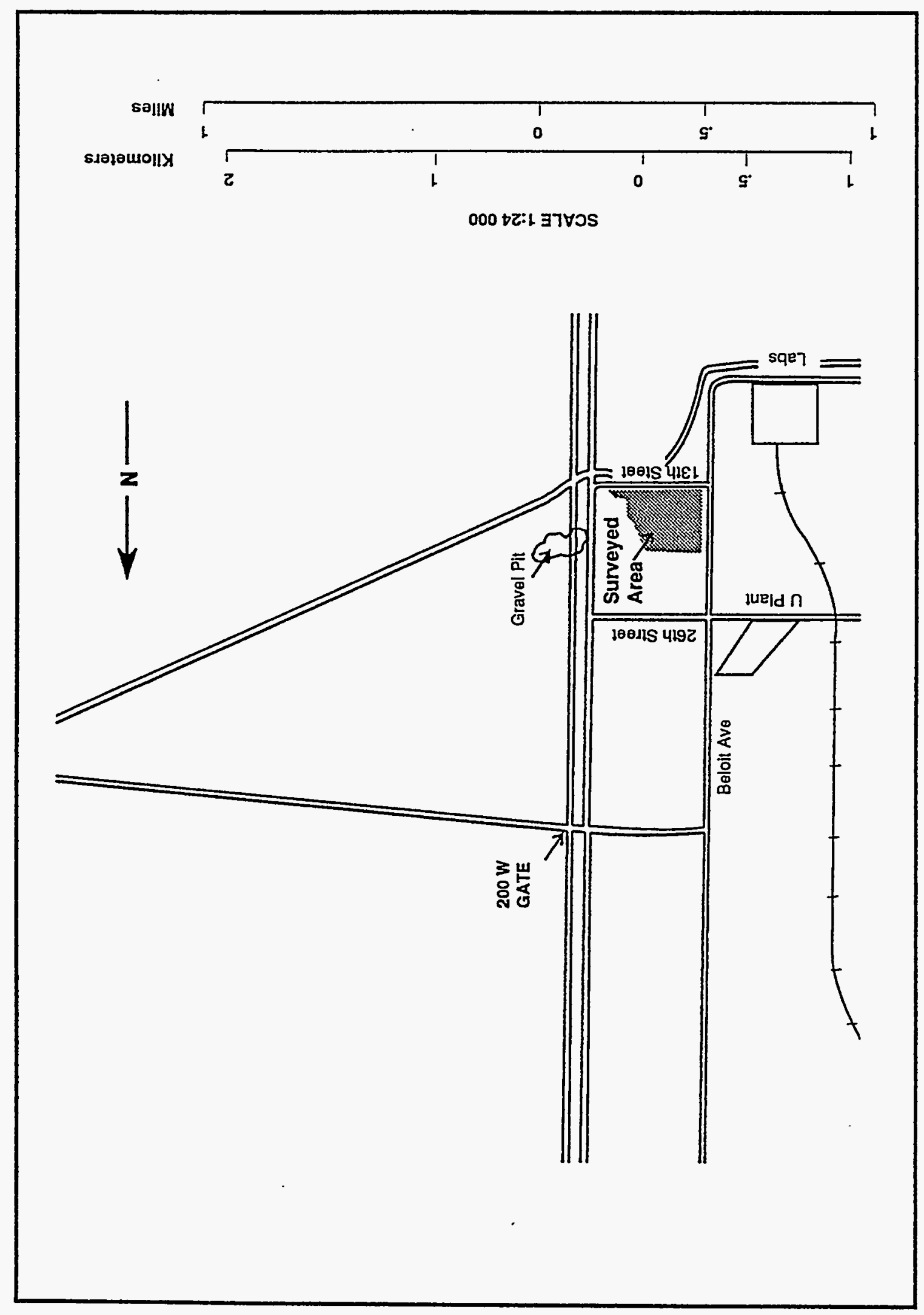

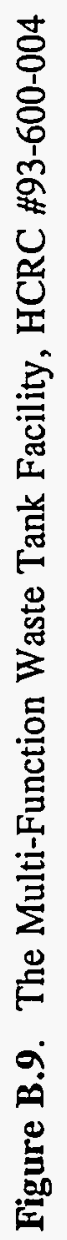

B. 28 


\section{HCRC \#93-600-005}

\section{The L-102 Primary Highway Route}

Project Description: The L-102 Primary Highway Route project originally involved a major upgrade of the primary and minor arterial highways, from the Wye Barricade to the Yakima Barricade. Because much of the project area was undisturbed and none of the route had been previously surveyed, the HCRL staff conducted a pedestrian survey (Figure B.10) from June 14 to June 23, 1993. The survey, conducted in transects spaced at $20-\mathrm{m}$ intervals, measured $9 \mathrm{~km}$ by $100 \mathrm{~m}$ between the Wye Barricade and the 200 East hill, $2.4 \mathrm{~km}$ by $60 \mathrm{~m}$ along the 200 East fence line between Canton Avenue and the third mile marker, $2.65 \mathrm{~km}$ by $60 \mathrm{~m}$ of the north and south section of Route 3 along the 200 West fence line, and $4.83 \mathrm{~km}$ by $60 \mathrm{~m}$ along the north side of Route $11 \mathrm{~A}$ between Route 6 and the Yakima Barricade.

An additional new roadway was added to the original project plan in September 1993. This road will be a two-lane highway connecting Route $4 \mathrm{~S}$ with $16^{\text {th }}$ Avenue, running parallel to Route 3 . HCRL staff conducted a survey of this addition on September 21, 1993.

Cultural Resources: Two historic sites were recorded during the survey of the original project. Site \#3-119 (HT-93-003) is a can scatter dated between 1915 and 1930. Site \#3-120 (HT-93-004) is a concrete block foundation with construction debris scattered throughout. No archaeological materials were found during the survey for the additional two-lane road. 


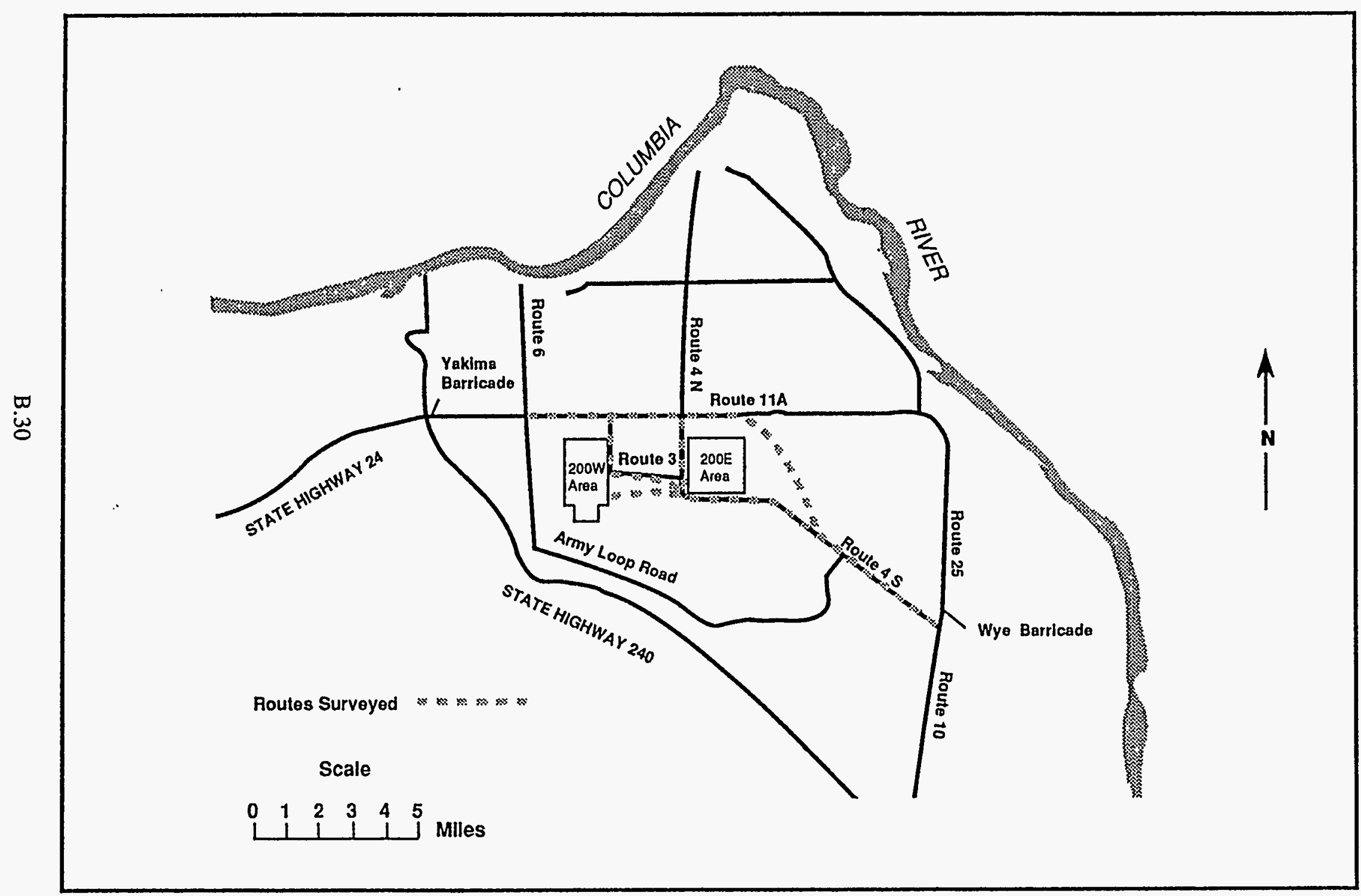

Figure B.10. L-102 Primary Highway Route North of the Wye Barricade, HCRC \#93-600-005. 


\section{HCRC \#93-600-011}

\section{Cultural Resources Review for the Microbial Origins Project Boreholes}

Project Description: This project originally entailed drilling six boreholes as close to existing roads as possible. A trailer-mounted auger rig will be used to drill the boreholes, which will measure

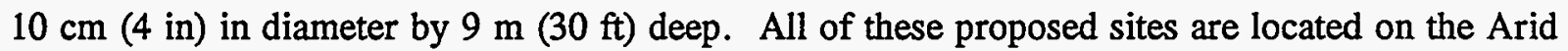
Lands Ecology Reserve at the following locations: the Benson Ranch, near the Lysimeter facility, north of Benson Spring, near Doke Spring, near Well 48-96, and near Gate 119. Later, a seventh borehole was added, located near the Doke Springs drainage.

Since all of the boreholes are to be located on undisturbed land, a pedestrian survey of the areas was performed for all but one borehole site. The location near Well 48-96 had been surveyed previously in 1990 (HCRC \#90-600-017). No cultural resources were identified during that survey. Staff of HCRL inspected the other five locations on March 29, 1993. The area surveyed at the Benson Ranch location measured $60 \mathrm{~m}$ by $180 \mathrm{~m}$; at the site above Benson Spring, $25 \mathrm{~m}$ by $80 \mathrm{~m}$; at the site near Gate $119,40 \mathrm{~m}$ by $60 \mathrm{~m}$; at the Lysimeter facility, $50 \mathrm{~m}$ by $80 \mathrm{~m}$; and at Doke Spring, $30 \mathrm{~m}$ by $30 \mathrm{~m}$. An additional area measuring $300 \mathrm{~m}$ by $25 \mathrm{~m}$ was surveyed on September 7, 1993 at the Doke Spring drainage.

Cultural Resources: Except for a fence line at Benson Ranch and a few species of biscuit root (Lomatium spp.), a possible food source found at Benson Spring, the Lysimeter facility, and Doke Spring, no archaeological or cultural materials were identified. 


\section{HCRC \#93-600-012}

\section{The Sagebrush Restoration Research Project}

Project Description: The Sagebrush Restoration Research project requires some surface disturbance in several locations on the ALE Reserve. Since the areas had had little to no prior disturbance and no previous surveys had been conducted, all areas were surveyed by HCRL staff on March 31, 1993. A total of approximately $0.20 \mathrm{~km}^{2}$ was surveyed.

Cultural Resources: No cultural materials were found during the survey. 


\section{HCRC \#93-600-013}

The Hanford IVDTS Job No. IVS and 300N Area

Project Description: This project involves placing a buried telephone cable 30 feet from Route 4 to the 300 North Area and 3 feet from the edge of the gravel and dirt roads to the ISV and 300 North Areas. Since the area was relatively undisturbed and no surveys had been conducted previously, the HCRL staff surveyed the entire project area on April 9, 1993. The survey covered approximately $0.02 \mathrm{~km}^{2}$.

Cultural Resources: No cultural materials were located during the survey. 


\section{HCRC \#93-600-014}

\section{The SR 240 Access Road}

Project Description: The State Route (SR) 240 Access Road project entails constructing a temporary access road connecting SR 240 with Beloit Avenue in the 200 West area. Intrusive work will include cut and fill activities extending to a depth between 3 and $6 \mathrm{~m}$. During the literature and records review, an examination of recent aerial photographs revealed that large portions of the proposed route were located in undisturbed land, and a check of HCRL's survey records showed that none of the area had been previously surveyed. HCRL staff completed a survey of the entire area on April 13, 1993. The survey, conducted in transects spaced at $20-\mathrm{m}$ intervals, covered a total of $0.01 \mathrm{~km}^{2}$.

Cultural Resources: Two historic sites were recorded during the survey. Site HT-93-001 is a lightdensity, historic debris scatter, consisting of five cans (which were collected) and several pieces of milled lumber. Site HT-93-002 is a high-density historic debris scatter containing approximately 40 cans and a jar. The cans from both sites date from between 1950 to 1987 . Neither site is considered to be eligible for the NRHP. 


\section{HCRC 93-600-016}

\section{The Hanford Well and Borehole Project}

Project Description: The Hanford Well and Borehole project involves setting 13 survey monuments on drivable aluminum rods. Each borehole will impact an area of approximately $1 \mathrm{~m}^{2}$ to a depth of $3 \mathrm{ft}$. The records and literature review showed that the 13 borehole locations were largely undisturbed, and that the areas for boreholes \#3, \#12, and \#13 had been previously surveyed during HRC \#88-200-009, \#87-600-008, and \#89-200-010, respectively. On April 13, 1993, HCRL staff conducted a survey of the remaining 10 borehole locations. A radius of $3 \mathrm{~m}$ was surveyed around each of the 10 locations.

Cultural Resources: No archaeological materials were found during the three previous surveys or the 1993 survey. 


\section{HCRC \#93-600-017}

The Washington Public Power Supply System Washington Nuclear Power Plant-2 Emergency Evacuation System Siren

Project Description: The WPPSS WNP-2 Emergency Evacuation System Siren project involves installing an emergency siren outside the ALE gate. The base of the structure will be pre-poured concrete, with a pole placed in the middle with four guide wires anchored to the ground. Because the literature and records review. and recent visits past the area revealed little prior disturbance and no surveys, an area measuring $.0009 \mathrm{~km}^{2}$ was surveyed on June 3, 1993, using transects spaced at $20 \mathrm{~m}$. Construction of the base and pole was monitored on September 7, 1993.

Cultural Resources: No cultural resources were found during either survey or monitoring. 


\section{HCRC \#93-600-019}

\section{The Hanford Patrol Power Line Extension Range}

Project Description: The Hanford Patrol Power Line Extension Range projects (Figure B.11) will provide electrical service to the Hanford Patrol Training Academy Range III by installing five electrical poles at intervals of $430 \mathrm{ft}$ at a depth of $6 \mathrm{ft}$. Since the literature and records review showed little disturbance and no prior surveys at the project area, a survey covering $0.12 \mathrm{~km}^{2}$ was conducted on May 13,1993. As the staff surveyed the area by walking two transects, disturbance at power poles \#1 and \#5 was evident. Since the remaining three poles were located in undisturbed ground, monitoring was required. On August 24, 1993, construction at poles \#2, \#3, and \#5 was monitored. The remaining poles were not monitored because no archaeological materials had been found in the area.

Cultural Resources: Modern debris was noted during the survey but not recorded. No other cultural material was found during the survey or monitoring. 


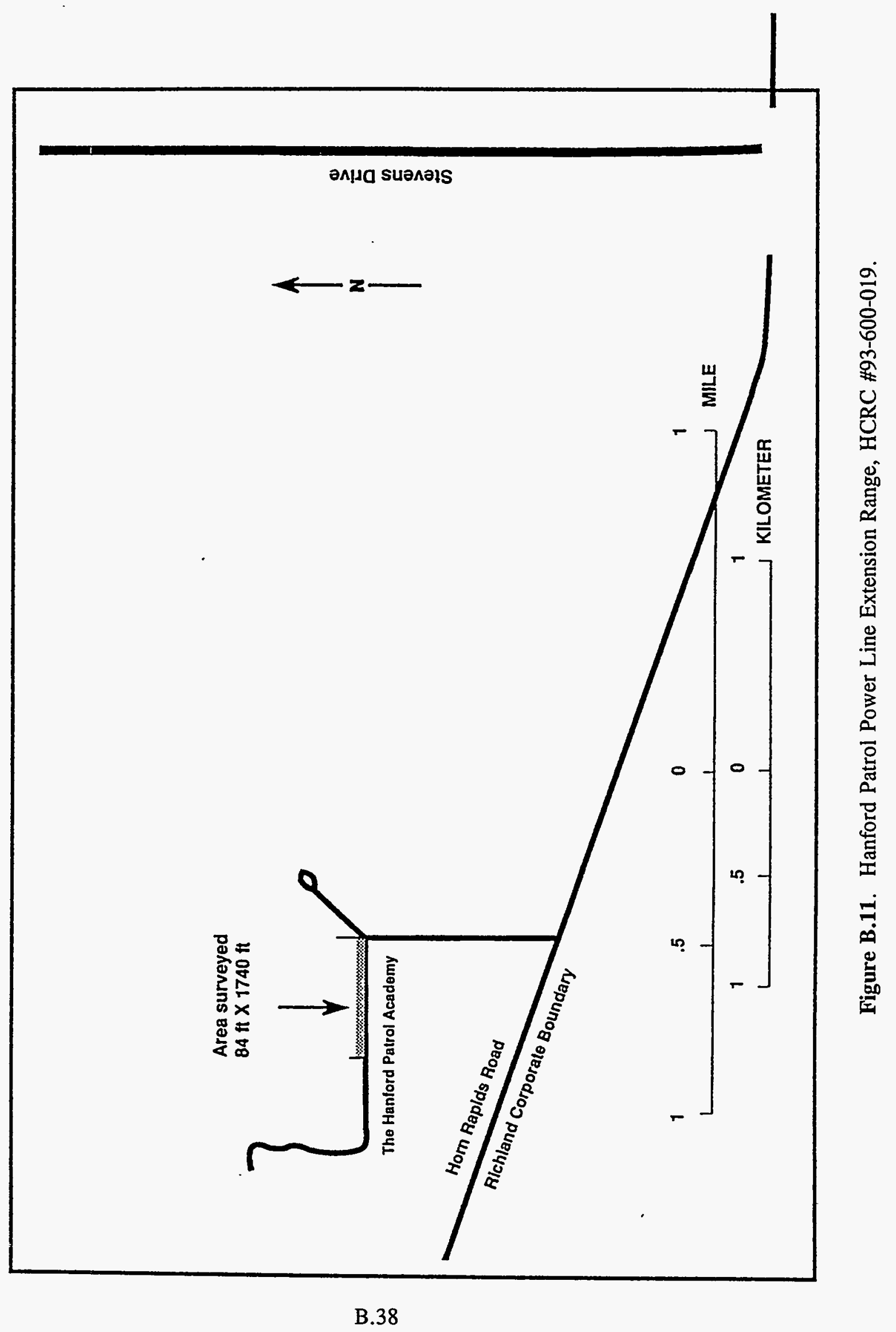




\section{HCRC \#93-600-021}

The Integrated Voice/Data Telecommunications System (IVDTS) Under SR 240

Project Description: The IVDTS under SR 240 project entails boring a hole to place $67 \mathrm{ft}$ of iron pipe under SR 240, 30 to 42 inches below its surface. One excavation is necessary on each side of the road, one approximately $10 \mathrm{ft}$ by $4 \mathrm{ft}$ and the other $4 \mathrm{ft}$ by $4 \mathrm{ft}$. Because the area on either side of SR 240 in the project area was relatively undisturbed, a $20 \mathrm{~m}$ by $40 \mathrm{~m}$ transect was walked on each side of SR 240 on May 26, 1993.

Cultural Resources: Modern debris including broken bottles were noted during the survey. No other cultural material was found. 
HCRC \#93-600-028

\section{W-152, ERDF Area}

Project Description: The W-152 project entails constructing up to 10 characterization/monitoring wells and associated access roads and drill pads within the ERDF area. Since the much larger ERDF project area encompassed the well and access road areas, the ERDF survey simply incorporated this project. Details concerning the ERDF survey can be found in Section 2.3 and earlier in Appendix B.

Cultural Resources: No archaeological or cultural materials were located within the area of potential effect of the well or access road areas. 


\section{HCRC \#93-0600-042}

\section{Survey of Selected Portions of ALE}

Project Description: The Survey of Selected Portions of the ALE Reserve project entails removing hazardous materials from nine locations in the control tower-observatory area on Rattlesnake Mountain; 30 locations in the former NIKE missile facility; and 25 locations in a former natural gas field north of and below Rattlesnake Mountain. In July 1993, the U.S. Army Corps of Engineers (USACE), led by John A. Draper, conducted the survey for the three areas. A survey covering $100 \%$ of the control tower-observatory area was conducted using transects spaced at $5 \mathrm{~m}$ intervals. Transects spaced at $20 \mathrm{~m}$ intervals were used to survey the NIKE missile facility. For the natural gas field, transects ranged from $10 \mathrm{~m}$ to $15 \mathrm{~m}$ apart depending on vegetation cover.

Cultural Resources: Twenty-seven sites were found during the survey, including two prehistoric sites, three sites containing both prehistoric and historic components, and 22 historic sites. It is the finding of the USACE that none of these sites is potentially eligible for the National Register.

Table B.5 summarizes these sites. 
Table B.5. Survey of Selected Portions of ALE.

\begin{tabular}{|c|c|c|c|}
\hline HCRL Site No. & State No. & Site Type/description & Collected? \\
\hline HT-93-044 & $3-126$ & Gas Well/Cistern & no \\
\hline HT-93-045 & $3-127$ & Gas Well/Cistern & no \\
\hline HT-93-046 & $3-131$ & Well/Cisterns & no \\
\hline HT-93-047 & $3-133$ & Cistern & no \\
\hline HT-93-048 & $3-135$ & Gas Well/Cistern/Flake & no \\
\hline HT-93-049 & $3-136$ & Well & no \\
\hline HT-93-061 & $3-123$ & Well/Cistern & no \\
\hline HT-93-062 & $3-124$ & Well/Cistern & no \\
\hline HT-93-063 & $3-125$ & Gas Well & no \\
\hline HT-93-064 & $3-128$ & Gas Well & no \\
\hline HT-93-065 & $3-129$ & Gas Well & no \\
\hline HT-93-066 & $3-130$ & Gas Well & no \\
\hline HT-93-067 & $3-132$ & Gas Well & no \\
\hline HT-93-068 & $3-134$ & Gas Well & no \\
\hline HT-93-069 & $3-137$ & Gas Well & no \\
\hline HT-93-070 & $3-139$ & Gas Well & no \\
\hline HT-93-071 & $3-140$ & Gas Well & no \\
\hline HT-93-072 & $3-141$ & Gas Well & no \\
\hline HT-93-073 & $3-142$ & Gas Well & $\overline{\text { no }}$ \\
\hline HT-93-074 & $3-138$ & Lithic Scatter/Gas Well & no \\
\hline HT-93-075 & $3-143$ & Lithic Scatter & no \\
\hline HT-93-076 & $3-147$ & Lithics/Gas Well & no \\
\hline HT-93-077 & $3-148$ & Foundation & no \\
\hline HT-93-078 & $3-149$ & Gas Well & no \\
\hline HT-93-087 & $3-144$ & Lithic Scatter & no \\
\hline HT-93-088 & $3-145$ & Gas Well & no \\
\hline HT-93-089 & $3-146$ & Gas Well & no \\
\hline
\end{tabular}




\section{HCRC \#93-0000-002}

\section{The DH-5 Abandonment}

Project Description: The DH-5 Abandonment project involves abandoning Well DH-5, located near Mattawa in Grant County. An excavation will be performed to access the well casing $6 \mathrm{ft}$ below grade. The casing will be cut $6 \mathrm{ft}$ below grade and removed. The well will be capped and the excavation backfilled. The literature and records review revealed that no prior survey had been performed in the project area. On May 25, 1993, a pedestrian survey was conducted by the HCRL staff that covered a total of $0.0005 \mathrm{~km}^{2}$ transects spaced $4 \mathrm{~m}$ apart.

Cultural Resources: No archaeological materials were found during the survey. 


\section{Appendix C}

Sites Monitored During the FY 1993 Monitoring Cycle 


\section{Appendix C}

\section{Sites Monitored During the FY 1993 Monitoring Cycle}

\section{BN90}

\section{National Register Status: Eligible}

Date of site visit: 27 September 1993

The site continues to be damaged by maintenance of the firebreak along the western edge of the site. A variety of prehistoric and historic artifacts were observed at the site. No other disturbance to the site or evidence of trespass was noted.

Recommendation: Update site form.

\section{BN104}

\section{National Register Status: Unevaluated}

Date of site visit: 27 September 1993

This site may have been first recorded as 45BN028. The site is located at an informal but popular boat launch. Since May of 1987 (when aerial photos were taken) a new dirt road has been created as the older tracks become impassable for boat trailers. Two of the older tracks are incised up to $1.5 \mathrm{~m}$ below surface. Two shell features were noted. One in the road bed which is currently being destroyed by vehicle traffic, and one in the side wall approximately $50 \mathrm{~cm}$ below surface. Other artifacts seen in the road beds in the vicinity of the boat launch are crude cobble tools, fire-cracked rock, and several cryptocrystalline silicate flakes.

The river bank is slumping to the north of the boat launch along a $20 \mathrm{~m}$ stretch, probably as a result of fluctuating river level. No collector digging was seen. Because the boat launch is well used and the road through the site also gets much pedestrian traffic, artifacts are undoubtedly being lost through surface collection. None of the artifacts mentioned by Rice (1968) (except for cobble tools) were found.

Recommendation: Auger to delimit site boundaries. Update site form and evaluate site significance. Either limit access or excavate areas most heavily used before more damage is done to the site.

\section{BN110}

\section{National Register Status: Listed}

Date of site visit: 4 October 1993

No recent anthropogenic disturbances were noted. Bad slumping is occurring along the south end of the bank as a result of fluctuating water levels. Site appears much the same as when last visited during the 1990 monitoring cycle.

Recommendation: Stabilize bank if necessary. Update site form. 


\section{BN119}

National Register Status: Listed

Date of site visit: 13 October 1993

A variety of historic and prehistoric artifacts were seen at this site. A cobble and boulder concentration, possibly a cairn, is located in part of the site subjected to wind erosion. The site is much larger than originally described. No recent anthropogenic disturbances were recognized.

Recommendation: Update site form.

\section{BN124}

\section{National Register Status: Listed/Cemetery}

Date of site visit: 21 September 1993

The cemetery is located in stabilized dunes and no disturbance was observed. A concentration of artifacts was observed outside the perimeter as delimited by cement monuments.

\section{BN125}

\section{National Register Status: Listed/Cemetery}

Date of site visit: 21 September 1993

Cairn burials as described in the original site form were not located (they had not been located on any previous monitoring trips). None of the diagnostic artifacts located during the 1989 monitoring cycle were relocated. A dirt road runs the length of the site and some recent trash was seen. Surface collection may be occurring, however the presence of net weights on the surface suggests that this activity is minor.

Recommendation: Update site form.

\section{BN128}

\section{National Register Status: Listed/Cemetery}

Date of site visit: 13 October 1993

Human remains were observed in areas undergoing erosion by the wind. No other disturbance or evidence of trespass was noted.

\section{BN129}

\section{National Register Status: Listed/Cemetery}

Date of site visit: 2 November 1993

This site has apparently been washed away, as recorded in 1991 (Chatters et al. 1992).

\section{BN130}

\section{National Register Status: Listed}

Date of site visit: 2 November 1993

Bank sediments containing stratified cultural deposits are slumping badly. This slumping is in large part the result of fluctuating water levels. The site as described during the 1990 monitoring cycle is still accurate. No other disturbance noted.

Recommendation: Update site form. Stabilize bank if necessary. 


\section{BN131}

National Register Status: Listed

Date of site visit: 4 October 1993

Three pits in a line appear to have been dug since the last monitoring cycle at this site, perhaps within the past year. A pile of artifacts was immediately adjacent to one of the pits and included flakes, faunal remains, and two biface fragments. Because the biface fragments were not collected, we infer that the individual(s) involved was not an amateur.

Recommendation: Increase surveillance. Update site form.

\section{BN139}

\section{National Register Status: Listed/Cemetery}

Date of site visit: 3 November 1993

We did not relocate or recognize the cairns noted in previous monitoring trips. Wind erosion is severe in the area.

\section{BN140}

National Register Status: Listed

Date of site visit: 3 November 1993

Wind continues to erode this site. Off-road vehicle tracks are located within the blowout area at the site. Surface collection may be occurring here, although no direct evidence was found.

\section{BN142}

National Register Status: On Washington State Register/Cemetery

Date of site visit: 3 November 1993

Most of the site is either stabilized with vegetation or covered by recently deposited aeolian deposits. Minor bank erosion is the only disturbance noted at the site. No evidence of looting or trespass was observed.

\section{BN143}

\section{National Register Status: On Washington State Register/Cemetery}

Date of site visit: 3 November 1993

Wind continues to erode the site. Very small bone fragments observed may be from burials. No evidence of looting or trespass was observed.

\section{BN145}

\section{National Register Status: Listed}

Date of site visit: 28 October 1993

Mat lodge depressions still apparent at this site as were cobble tools, cores, and an anvil stone. No diagnostic tools as described by Rice (1968) were located. The site appears in good condition. No recent disturbance was seen.

\section{BN150}

\section{National Register Status: Listed}

Date of site visit: 28 October 1993

This was the first recorded visit to the site since the initial recording in 1968. The site is somewhat longer than originally described. Two possible housepit depressions were noted. Concentrations of 
fire-cracked rock, shell, cobble tools, large mammal bones, and a few flakes were observed weathering out of the cutbank. Shell fragments were seen in animal burrow backdirt up to $50 \mathrm{~m}$ inland of the terrace edge. Exact dimensions of the deposits are difficult to ascertain because of the dense vegetation covering much of the site, and because a main component appears to be buried. Wind and bank erosion is occurring at this site. A little-used dirt road parallels the bank within the site boundaries.

Recommendation: Update site form.

\section{BN151}

\section{National Register Status: Listed/Cemetery}

Date of site visit: 27 September 1993

Most of the site is stabilized with thick vegetation cover and appears in good condition. A dirt road crosses the site and off-road vehicle tracks were observed. Repairs are needed on several of the signs that state that no excavations are to occur inside the boundary of the signs.

Recommendation: Educate Hanford Site workers not to drive off of established roads. Repair signs.

\section{BN157A}

\section{National Register Status: Eligible}

Date of site visit: 29 October 1993

This site continues to receive extensive damage. Stock damage continues to be significant on the west end of the site. Surface collection activities are active as evidenced by several piles of flakes. Other disturbance includes off-road vehicle traffic, minor bank erosion and wind erosion. Additionally, a firebreak was created to contain the fire that started July 4, 1993. Artifacts were observed within the firebreak and piles of flakes were seen adjacent to it. Several fresh-appearing looter pits and what may be filled-in pits were seen at the east end of the site. These may be more recent excavations than those observed in 1991.

Recommendation: Increase surveillance. Install new signs detailing laws and consequences of illegal collection activities. Stock should be removed from the Hanford Site boundaries. If vandalism cannot be curtailed, data recovery should be considered as an option before the entire deposit is destroyed.

\section{BN157B}

\section{National Register Status: Eligible/Cemetery}

\section{Date of site visit: 17 September 1993}

No evidence of recent trespass was seen inside the fence, however the chain link is deformed on the gate where it appears people climb over the top. Wind continues to erode the site. Outside of the fence, disturbance done by horses is exacerbating the wind erosion. Surface collection may have increased as a result of a fire this summer which removed much of the vegetation.

Recommendation: Increase surveillance. Install new signs detailing laws and consequences of illegal collection activities. Stock should be removed from the Hanford Site boundaries. 


\section{BN173}

National Register Status: Listed

Date of site visit: 15 September 1993

This site was not relocated during the 1990 monitoring cycle. The site was recorded in 1968 as an open campsite with a few flakes, bone fragments, and fire-cracked rock. An antler and pestle were also observed at that time. The site is currently covered by dense vegetation. A dirt road, incised about $40 \mathrm{~cm}$ below surface, crosses the site. A cryptocrystalline silicate flake and core within the roadway, and a biface in the road berm in some rodent excavations was observed. Historic features are also present at this site. A trench, perhaps dating to army maneuvers in the late $1950 \mathrm{~s}$, is in the site vicinity. Dimensions of the deposits are difficult to ascertain because of the dense vegetation cover. No recent disturbance to the site other than the road was observed.

Recommendation: Auger to define site boundaries and update site form.

\section{BN178}

\section{National Register Status: Listed}

Date of site visit: 28 September 1993

Fresh tire tracks and footprints were observed at the site. The informal road dead ends at the site, and since no facilities are located here, it is inferred that the site is the destination point. The footprints were located in the blowouts where artifacts are concentrated. It is rumored that this site is a favorite collection spot for workers. Wind continues to erode this site.

Recommendation: Increase surveillance. Educate workers regarding laws protecting sites. Update site form.

\section{BN424}

\section{National Register Status: Unevaluated}

Date of site visit: 27 September 1993

No disturbance to the site was seen. The site appears as it was described in 1991.

\section{BN427}

\section{National Register Status: Unevaluated/Eligible/Possible burials}

Date of site visit: 28 September 1993

Within the last few months approximately 25 large rocks were removed from along the edge of the mesa, and were probably thrown over the side. More serious human-induced damage to the land form was noted in 1990 when boulder-sized pieces of the mesa had been pried off the edge. The hill is considered sacred to local Indian people and this damage may be considered desecration. No recent disturbance was noted for the numerous cairns and rock features that are present at the site, however because damage to the land form is recurring in the same area as the features, potential for damage to them is high. Off-road vehicle tracks led to the base of the site. This site includes sites 45BN354 and 45BN355, which may be burial cairns.

Recommendation: Discourage Hanford Site workers from unauthorized visits to the site. Educate workers not to drive off established roadways. 
45FR258

National Register Status: Listed/Possible burial

Date of site visit: 4 October 1993

Collector digging observed at 45FR258 along the shoreline at the edge of the bank appeared to have

been done recently. Scratchings in the cutbank appear more weathered. Additionally, fresh prints

(made the same day as our visit) were observed at the site. In addition to digging, surface collection is suspected at this site. Wind is eroding areas at the south end of the site.

Recommendation: Increase surveillance. Update site form.

45FR260

National Register Status: Listed

Date of site visit: 4 October 1993

Minor wind erosion is occurring at the site, but vegetation is recovering since the removal of stock sometime since the last site visit in 1989.

Recommendation: Update site form.

45FR265

National Register Status: Unevaluated

Date of site visit: 29 October 1993

This is the first recorded visit to the site since it was recorded in 1968 when cobble tools, pestles, and corner-notched projectile points were noted. The site was not relocated in the area as originally described. Dense vegetation obscured the surface of both the river shore, and on the terrace where the site was originally mapped. Infrequent fire-cracked rocks and cobbles were observed in the cutbank approximately $0.5 \mathrm{~m}$ below the ground surface. A few flakes were found on the surface in association with historic artifacts and features, and a few fire-cracked rocks and cobble tools were seen on the beach where vegetation cover was sparse. Surface collection is suspected.

Recommendation: Auger to delimit site boundaries, update site form, and evaluate site.

\section{FR266}

\section{National Register Status: Unevaluated}

Date of site visit: 29 October 1993

No new disturbance to the historic component of the site was recognized. Intact sediments at the site, however, were disturbed by construction of a levee since the waste water return washout earlier in 1993. Damage appeared to be minor, however, a Request for Cultural Resource Review should have been submitted prior to this action. Surface collection is occurring as evidenced by a pile of flakes observed on the beach. Natural bank erosion is occurring by wind and water.

Recommendation: Increase site surveillance, update site form and evaluate site. Educate agencies regarding the Cultural Resource Review process.

\section{GR302A}

National Register Status: Listed

Date of site visit: 2 November 1993

Several recent shallow looting pits were observed on the south tip of the site. These occurred on the 
beach and bank below the high water line. Surface collection is taking place as evidenced by a small pile of lithic debitage left on the beach. Further up the bank, backdirt from an old excavation is being badly eroded by the wind. Little vegetation is growing on this backdirt pile. The units excavated by the Mid-Columbia Archaeological Society are still open. Other disturbance to the site included some bank undercutting by the river. Most of the site is covered by thick vegetation which protects the site from surface collection, although housepit depressions are apparent.

Recommendation: Revegetate where needed. Fill in units excavated by the Mid-Columbia Archaeological Society for safety reasons as well as to stop slumping of the walls and to discourage unauthorized digging. Increase surveillance. Update site form.

\section{GR302C}

\section{National Register Status: Listed/Cemetery}

Date of site visit: 2 November 1993

Most of this site is covered by thick vegetation. No surface indications of burials were recognized. Wind erosion is occurring in small areas at the northwest corner of the site. No anthropogenic disturbances were observed.

Recommendation: Update site form.

\section{GR303}

\section{National Register Status: Listed}

Date of site visit: 2 November 1993

This was the first recorded visit to the site since the initial recording in 1968 . The site appears to be contiguous with cultural deposits to the northwest including site 45GR304. Artifacts were found in beach lag deposits and in bank slump and soil fall deposits for most of the distance $(950 \mathrm{~m})$ between sites 45 GR 303 and 45 GR304 (as originally recorded). A dense concentration of cryptocrystalline silicate debitage and fire-cracked rocks were at the south end of this site. To the northwest, several buried soil horizons and cultural deposits including a hearth and possible housepits were noted in the bank. Dense vegetation covers the surface of the terrace, limiting our ability to define the site boundaries. Disturbance to the site includes bioturbation (mainly from swallows and coyotes) and soil fall and slumping exacerbated by fluctuating river levels.

Recommendation: Update site form. Stabilize bank or consider data recovery.

\section{GR304}

\section{National Register Status: Listed}

Date of site visit: 2 November 1993

This was the first recorded visit to the site since the initial recording in 1968. The site appears to be contiguous with cultural deposits to the southeast including site 45GR303. Artifacts were found in beach lag deposits and in bank slump and soil fall deposits for most of the distance $(950 \mathrm{~m})$ between the two sites (as originally recorded). Artifacts seen include fire-cracked rocks, cobble tools, horse bones, shells, and lithic debitage. Several buried soil horizons and cultural deposits, including a shell lens, were noted in the bank at the north end of the site. Dense vegetation covers the surface of the 
terrace limiting our ability to define the site boundaries. Disturbance to the site includes bioturbation (mainly from swallows and coyotes) and soil fall and slumping exacerbated by fluctuating river levels.

Recommendation: Update site form. Stabilize bank or consider data recovery.

\section{GR306A}

National Register Status: On Washington State Register/Possible burials

Date of site visit: 3 November 1993

Several piles of cobbles and boulders, possibly collapsed cairns, were observed in the dunes. Wind erosion has exposed small bone fragments including cranium fragments which were found in association with one of these concentrations. The bones are presumed to be human burial remains.

The site is a popular stopping spot for recreationists. Recent trash, fire rings, and rock piles for fishing poles were found within the site boundary. Other disturbance includes recent vehicle tracks, both from two-wheeled and four-wheeled vehicles, and wind erosion. Surface collection is suspected because of the absence of formed tools and looting activity at the adjacent site (45GR306B).

Recommendation: Increase surveillance. This site is vulnerable to vandalism as evidenced from the looting at 45GR306B. Update site form.

\section{GR306B}

\section{National Register Status: On Washington State Register}

Date of site visit: 3 November 1993

Over 80 pits, dug by looters, were found in three areas of the site on the terrace over $50 \mathrm{~m}$ from the river. These pits had been made within the previous year. These appeared to have been dug over successive trips to the site as some appeared less eroded than others. The holes, which measured 20 to $40 \mathrm{~cm}$ in diameter and 10 to $30 \mathrm{~cm}$ deep, were dug with a tined tool. These were dug in a broad swale which would have hidden the vandals from view.

The site is a popular stopping spot for recreationists. Recent trash, fire rings, and rock piles for fishing poles were found within the site boundary. Other disturbance includes recent vehicle tracks and wind erosion. Surface collection is suspected because of the absence of formed tools and the looting activity at the site.

Recommendation: Increase surveillance. Update site form.

\section{GR306C}

\section{National Register Status: Cemetery/On Washington State Register}

Date of site visit: 3 November 1993

Several bone fragments, including pieces of cranium, were observed in two separate areas of the cemetery in a blowout. Both burned and unburned bones were observed. These bones are presumed to be human burial remains. Most of the area of the site, as initially recorded, is in stabilized dunes, which are often covered with dense vegetation. Wind erosion was the only disturbance noted at the site.

Recommendation: Update site form. 


\section{GR307}

\section{National Register Status: Unevaluated}

Date of site visit: 4 November 1993

This is the first recorded visit to the site since it was recorded in 1968. Discontinuous artifact concentrations were located in the area originally mapped as the site. Artifacts noted include shell, fire-cracked rock, lithic debitage, cobble tools, cores, anvil stones, and milling stones. Historic features located include a rock alignment, perhaps marking the edge of a road, and a well casing. Several round depressions on the cobble/boulder veneered lowest terrace are enigmatic, perhaps being housepit depressions or mining disturbances. Similar features are noted at several sites along the river (e.g., 45GR317). Artifacts are apparent only in blowouts, cutbanks, or on the deflated low terrace surface. The site appears to be stratified, buried to a depth of at least $2 \mathrm{~m}$. Disturbance to the site is occurring principally by wind erosion. Modern trash was observed at the site and surface collection may have occurred.

Recommendation: Update site form and evaluate site.

\section{GR315}

\section{National Register Status: Unevaluated}

Date of site visit: 5 November 1993

Few and scattered artifacts were found in the original site boundaries as defined by Rice (1968). Artifacts include lithic debitage, a notched cobble tool, shell, and the base of a contracting stem projectile point, probably from the Tucannon phase. The site, which was identified in 1989 , located $250 \mathrm{~m}$ west of the original site boundary of $45 \mathrm{GR} 315$, was also revisited as there was evidence of recent vandalism at that time. Several recently dug pits of possible human origin were found at the site. Their morphology resembled the morphology of the vandal pits found at 45GR306B. Minor wind erosion is occurring along the bank at this site.

Recommendation: Update site form and evaluate site. Increase surveillance.

\section{GR317}

\section{National Register Status: Listed/Burials reported}

Date of site visit: 5 November 1993

No recent signs of vandalism were noted at the site. Scratchings that were observed in the cutbank did not appear fresh. Artifacts were only observed in the cutbank, as the terrace surface and beach are now densely vegetated. The heavy vegetation cover protects the site from casual collectors. No human remains were observed at the site, as were originally recorded in 1968.

Recommendation: Update site form.

45GR319

National Register Status: Unevaluated

Date of site visit: 17 September 1993

This is the first monitoring trip to this site. The site as originally mapped and described could not be 
located. Historic gold mining features, however, are present along the river bank. The area is a popular fishing and recreational area, modern fire hearths and numerous modern rock piles for fishing poles are present near the bank.

Recommendation: Update site form.

45GR619

National Register Status: Unevaluated

Date of site visit: 12 July 1993

This site appears to be in much the same shape as it was originally described in 1989 . This is the first visit to the site since it was recorded. No new disturbance was seen.

Recommendation: Evaluate site.

\section{HT-87-019}

National Register Status: Eligible/Possible burials

Date of site visit: 17 September 1993

This is the first year that this site has been monitored since it was recorded in 1987. The site was described as containing 17 cairns, which were presumed to be graves. We located 18 such cairns, 2 of which appeared to be disturbed. The disturbance to these cairns was also noted in 1987, and the disturbed ground had been revegetated. No new disturbances to the site were observed.

Recommendation: Submit site form to the state to obtain permanent site number. 


\section{Appendix D}

\section{Presentations and Publications by the HCRL Staff in FY 1993}




\section{Appendix D}

\section{Presentations and Publications by the HCRL Staff in FY 1993}

\section{Presentations to Lay Organizations and Schools}

"Hanford Cultural Resources." Department of Ecology. Richland, Washington. October 26, 1992. M. K. Wright.

"An Introduction to the Archaeology of the Prehistory of the Columbia Valley." Sixth grade class at Highlands Middle School. Kennewick, Washington. January 19, 1993. M. V. Dawson.

"An Introduction to Archaeology." "Expanding Your Horizons" Conference sponsored by the American Association of University Women and the Society of Women Engineers. Richland, Washington. March, 1993. M. V. Dawson.

"Introduction to Archaeology." Students from the Tri-City Area Vocational Skills Center. Richland, Washington. April 14, 1993. M. K. Wright, M. V. Dawson, M. E. Crist, and J. G. Longenecker.

"Arid Lands Ecology Reserve." Washington State University Professors. Richland, Washington. April 22, 1993. M. K. Wright.

"The Hanford Cultural Resources Laboratory." The Center for the Analysis of Environmental Change. Richland, Washington. May 14, 1993. M. K. Wright, M. V. Dawson, M. E. Crist, and J. G. Longenecker.

"Rattlesnake Mountain." Washington District Court Judges. Richland, Washington. May 18, 1993. M. K. Wright.

\section{Technical Reports}

Hanford Cultural Resources Laboratory Annual Report for Fiscal Year 1992. PNL-8676, Pacific Northwest Laboratory, Richland, Washington. J. C. Chatters, H. A. Gard, M. K. Wright, M. E. Crist, J. G. Longenecker, T. K. O'Neil, and M. V. Dawson.

Fiscal Year 1992 Report on Archaeological Surveys of the 100 Areas, Hanford Site, Washington. PNL-8819, Pacific Northwest Laboratory, Richland, Washington. M. K. Wright. 


\section{Distribution}

No. of

Copies

2 DOE/Office of Scientific and Technical Information

State Historic Preservation Officer Office of Archaeology \& Historic Preservation

111 West 21st Ave., KL-11

Olympia, WA 98504-5411

2 R. Buck, Jr.

The Wanapum Indian Tribe

Attn: Tribal Council

P.O. Box 275

Beverly, WA 99321

B. Crespin

U.S. Bureau of Land Management

Burns, OR 97720

2 A. Fredin

Colville Confederated Tribes

Attn: Tribal Council

P.O. Box 150

Nespelem, WA 99155

D. Hogan

U.S. Army Corps of Engineers

Box C-3755

Seattle, WA 98124-2255

J. Leier

U.S. Army Corps of Engineers

Walla Walla District

Building 602, City-County Airport

Walla Walla, WA 99362-9265
No. of

Copies

2 J. Meninik

The Yakama Indian Nation

P.O. Box 151

Toppenish, WA 98948

Attn: Tribal Council

R. Jim

2 D. Powaukee

Nez Perce Tribe

P.O. Box 305

Lapwai, ID 83540

Attn: Tribal Council

J. H. Reuben

K. Sycamore

National Park Service,

Pacific Northwest Region

83 King St., Suite 212

Seattle, WA 98104

2 P. D. Teel

Washington Department of Ecology

7601 W. Clearwater, Suite 102,

Kennewick, WA 99336

3 J. R. Willkinson

The Confederated Tribes of the Umatilla Indian Reservation

P.O. Box 638

Pendleton, OR 97810

Attn: Tribal Council

J. Van Pelt

R. George

3 Washington Department of Ecology

99 S. Sound Center

Lacey, WA 98504

Attn: C. Cline

S. F. Cross

L. Goldstein 
No. of

Copies

ONSITE

32 DOE Richland Operations Office

P. F. Dunigan

A5-15

B. L. Foley

E. D. Gollen (10)

J. D. Goodenough

N. M. Highland

M. B. Hitt

R. D. Izatt

C. R. Pasternak (12)

E. E. Pride

J. R. Shadel

DOE Legal Library

Public Reading Room
A5-19

A5-19

A5-19

A7-27

A7-27

A5-15

A7-27

A4-52

A5-90

A4-78

A1-65
No. of

Copies

$4 \quad$ U.S. Environmental Protection Agency

P. R. Beaver

B5-01

D. A. Faulk

B5-01

L. E. Gadbois

B5-01

P. S. Innis

B5-01

33 Westinghouse Hanford Company

M. R. Adams

J. M. Ayres

H6-01

H6-02

R. L. Biggerstaff

H6-02

J. R. Culmer

$\mathrm{X} 0-21$

R. H. Englemann

H6-26

T. W. Ferns

H6-26

H6-07

G. E. Fitzgibbon

$\mathrm{X} 0-21$

K. A. Gano

H6-02

H6-02

G. C. Henckel

R. P. Henckel

C. J. Hostetler

W. L. Johnson

A. D. Krug

M. J. Lauterbach

R. M. Mitchell

N. M. Naiknimbalkar

K. L. Peterson

F. V. Roeck

J. W. Roberts

$\mathrm{H} 6-02$

M. T. Stankovich

H6-02

S. E. Vukelich

H6-02

D. J. Watson

$\mathrm{X} 0-41$

R. S. Weeks

H6-26

S. G. Weiss (5)

H6-02

Central Files

L8-04

EDMC (3)

H4-22

38 Pacific Northwest Laboratory

E. J. Antonio

K6-61

S. L. Friant

K6-52

R. H. Gray

K1-33

M. C. Holthoff

P7-79

R. E. Jaquish

K1-30

G. V. Last

K6-96

J. G. Longenecker (20)

K6-60

T. K. Lucas

K6-52

P. Nickens

K6-60

R. C. Phillips

P7-79

L. E. Rogers

K6-63

M. K. Wright

K6-60

Publishing Coordination

Technical Report Files (5)

K1-06

Routing

R. M. Ecker

SE-UI

M. J. Graham

K6-80

P. M. Irving

K6-98

R. L. Skaggs

K6-77

C. S. Sloane

K6-04

P. C. Hays

K6-86

J. O'Mara (last)
H6-02

K6-81

H6-04

H6-02

H6-01

H6-04

H6-02

H4-14

H4-55 